\title{
Zentrale und periphere Populationen von Hornungia petraea: Biodiversität und Demographie auf unterschiedlichen raum-zeitlichen Skalenebenen
}

\author{
Dissertation zur Erlangung des Doktorgrades \\ der Mathematisch-Naturwissenschaftlichen Fakultäten \\ der Georg-August-Universität zu Göttingen
}

vorgelegt von

Christian Kluth geb. Schulz

aus Karlsruhe

Göttingen 2004 
D 7

Referent: Prof. Dr. Helge Bruelheide

Korreferent: Prof. Dr. Michael Runge

Tag der mündlichen Prüfung: 27.04.2004 
1 Zentrale und periphere Populationen von Hornungia petraea: Biodiversität und Demographie auf unterschiedlichen raum-zeitlichen Skalenebenen

Einleitung

Das Untersuchungsobjekt Hornungia petraea 2

Untersuchungsgebiet, Untersuchungsflächen und Beprobungsdesign 3

Biodiversitätsmuster über verschiedene Skalenebenen 4

Ergebnisse und Schlussfolgerungen 5

Zentrale und periphere Populationen: Muster und Dynamik 6

Ergebnisse und Schlussfolgerungen 6

$\begin{array}{ll}\text { Übergangsraten zwischen Lebensstadien } & 7\end{array}$

Ergebnisse und Schlussfolgerungen $\quad 8$

$\begin{array}{ll}\text { Ausblick } & 9\end{array}$

2 Using standardised sampling designs from population ecology to assess biodiversity patterns of therophyte vegetation across scales 11

Introduction $\quad 12$

$\begin{array}{ll}\text { Material and Methods } & 15\end{array}$

Field sampling 15

Data analysis 17

Dissimilarity index $\bullet$ Species accumulation $\bullet$ Similarity decay

$\begin{array}{ll}\text { Test statistics } & 19\end{array}$

Results $\quad 20$

Species richness of subplots, plots and regions 20

Dissimilarity between subplots, plots and regions 21

Species accumulation curves $\quad 22$

Relationships between different diversity levels 23

Diversity and plot area 24

Similarity decay 25

Discussion $\quad 26$

Consequences of the study design 26

Appropriateness of species accumulation curves 27

Comparison of diversity between Germany and Italy 28

Relationships between different diversity levels 30

Diversity and inter-plot distance (Similarity decay) 32 
3 Central and peripheral Hornungia petraea populations: patterns and dynamics 35

Introduction $\quad 35$

$\begin{array}{ll}\text { Methods } & \mathbf{3 8}\end{array}$

$\begin{array}{ll}\text { Study object } & 38\end{array}$

$\begin{array}{ll}\text { Study sites } & 39\end{array}$

Plot design and field sampling $\quad 39$

$\begin{array}{ll}\text { Seed bank analysis } & 40\end{array}$

$\begin{array}{ll}\text { Test statistics } & 40\end{array}$

Results $\quad \mathbf{4 1}$

Adult plant population density 41

Population dynamics $\quad 44$

Seed bank population $\quad 45$

$\begin{array}{ll}\text { Fecundity } & 47\end{array}$

Discussion $\quad 49$

4 Transition rates between life cycle stages in natural populations of the annual plant Hornungia petraea: The combined effect of density-dependence, range position and inter-annual dynamics 53

Introduction $\quad 54$

$\begin{array}{ll}\text { Methods } & \mathbf{5 7}\end{array}$

Study object $\quad 57$

$\begin{array}{ll}\text { Study plots } & 57\end{array}$

Plot design and field sampling $\quad 58$

$\begin{array}{ll}\text { Data analysis } & 59\end{array}$

$\begin{array}{ll}\text { Test statistics } & 60\end{array}$

$\begin{array}{ll}\text { Results } & 61\end{array}$

Fecundity $\quad 61$

Total transition into the seed bank 62

$\begin{array}{ll}\text { Germination rate } & 63\end{array}$

$\begin{array}{ll}\text { Winter survival rate } & 64\end{array}$

$\begin{array}{ll}\text { Reproduction rate } & 65\end{array}$

Summarised results of all transition rates 66

$\begin{array}{ll}\text { Discussion } & \mathbf{6 6}\end{array}$

$\begin{array}{ll}\text { Range position and density-dependence } & 67\end{array}$

$\begin{array}{ll}\text { Range position and dynamics } & 68\end{array}$

$\begin{array}{ll}\text { Interaction of range position and density } & 69\end{array}$

$\begin{array}{ll}\text { Conclusions } & 69\end{array}$

$\begin{array}{ll}\text { Literaturverzeichnis } & 71\end{array}$

$\begin{array}{ll}\text { Zusammenfassung } & 79\end{array}$

Danksagung $\quad 82$

$\begin{array}{lr}\text { Lebenslauf } & 83\end{array}$

$\begin{array}{lr}\text { Publikationen } & 85\end{array}$ 




\section{Zentrale und periphere Populationen von Hornungia petraea:}

Biodiversität und Demographie auf unterschiedlichen raum-zeitlichen Skalenebenen

\section{Einleitung}

Der Vergleich von Populationen einer Art oder von Biozönosen über ihr gesamtes Areal ist von besonderem biogeographischem und evolutionsökologischem Interesse. Für dieses großräumige Skalenniveau ergibt sich im Kontext der makroökologischen Forschung eine Vielzahl von Mustern und Hypothesen (siehe Sagarin \& Gaines 2002b; Blackburn \& Gaston 2003) unter anderem hinsichtlich der Verteilung einzelner Arten (z.B. Gaston et al. 2000; Sagarin \& Gaines 2002a; Sagarin \& Gaines 2002b; McGill \& Collins 2003) sowie mehrerer Arten, d.h. für die sich daraus ergebende Biodiversität (Godfray \& Lawton 2001; Whittaker et al. 2001; Willis \& Whittaker 2002). Für den Naturschutz sind weite räumliche Skalen von besonderer Bedeutung im Hinblick auf ein vermutlich höheres Aussterberisiko von Populationen am Rande ihrer Verbreitung sowie ihr Verhalten gegenüber anthropogenen Umweltveränderungen (z.B. Lawton 1993; Safriel et al. 1994; Lesica \& Allendorf 1995; Thomas et al. 2004).

Für einzelne Arten ergeben sich die erwarteten Muster ihrer Verteilung über ihre geographische Verbreitung im wesentlichen aus ökologischen und evolutionären Prozessen, die im kausalen Gedankenmodell des „,entral-marginal model““ (Mayr 1965; Lewontin 1974; Brussard 1984) zusammengefasst sind. Dabei wird zunächst angenommen, dass abiotische, d.h. im wesentlichen klimatische Faktoren bewirken, dass eine Art auf ein bestimmtes Areal begrenzt ist. Diese klimatischen Faktoren werden zum Arealrand einer Art hin als zunehmend ungünstig erachtet. Die ungünstigeren klimatischen Bedingungen am Arealrand führen zu einer reduzierten Reproduktion in peripheren Populationen und entsprechend zu niedrigeren Populationsdichten als im Zentrum der Verbreitung. Aufgrund der niedrigen Populationsdichten wird eine genetische Verarmung innerhalb peripherer und kleiner Populationen angenommen.

Den verschiedenen Prozessen und erwarteten Mustern in dieser Gedankenkette wurde jedoch in der Literatur sehr unterschiedlich intensiv Rechnung getragen. Gerade die am Ende stehende Erwartung der geringeren genetischen Varianz peripherer Populationen im Vergleich zu zentralen Populationen wurde in letzter Zeit dank effizienter molekulargenetischer Methoden intensiv für eine Vielzahl von Organismen untersucht (z.B. Oyama 1998; Durka 
1999; Lammi et al. 1999; Jonas \& Geber 1999; Shea \& Furnier 2002; Lönn \& Prentice 2002; Tyler 2002). Die weiteren Aspekte des „central-marginal model“ wurden hingegen insbesondere für Pflanzenarten sehr viel weniger berücksichtigt, obwohl Brussard schon 1984 auf die Wichtigkeit demographischer Aspekte im ,central-marginal model“" hingewiesen hat.

In der vorliegenden Arbeit werden beispielhaft für das Untersuchungsobjekt Hornungia petraea (L.) RCHB. periphere deutsche Populationen der Art mit zentralen Populationen in Italien verglichen. In Kapitel 2 (Kluth \& Bruelheide 2004c) werden anhand des Vorkommens von $H$. petraea Diversitätsmuster dieser Pflanzengesellschaften über mehrere räumliche Skalen untersucht. Kapitel 3 (Kluth \& Bruelheide 2004a) geht auf die raum-zeitlichen Muster ein, die für das Untersuchungsobjekt $H$. petraea aus dem „,central-marginal model“ zu erwarten sind. In Kapitel 4 (Kluth \& Bruelheide 2004b) werden sodann mögliche demographische Ursachen zur Erklärung unterschiedlicher Populationsdichten zentraler und peripherer Vorkommen von H. petraea genauer beleuchtet.

\section{Das Untersuchungsobjekt Hornungia petraea}

Die Zwerg-Steppenkresse Hornungia petraea ist eine kleine, bis maximal $15 \mathrm{~cm}$ hohe winterannuelle Brassicaceae. Die Art keimt im Herbst und produziert bis in den Winter hinein gefiederte Blätter in einer Grundrosette. Bereits im Vorfrühling beginnt mit der Blütenbildung die generative Phase (Abb. 1). Die Früchte reifen im Frühling nacheinander heran und die reifen Samen, vier pro Schötchen, werden in der Regel Ende April/Anfang Mai ausgestreut. Die adulten Pflanzen sterben während der Fruchtreifung ab. Nach dem Übersommern der Samen schließt sich der Lebenszyklus. Die Art baut eine persistente Samenbank auf (sensu Thompson \& Grime 1979).

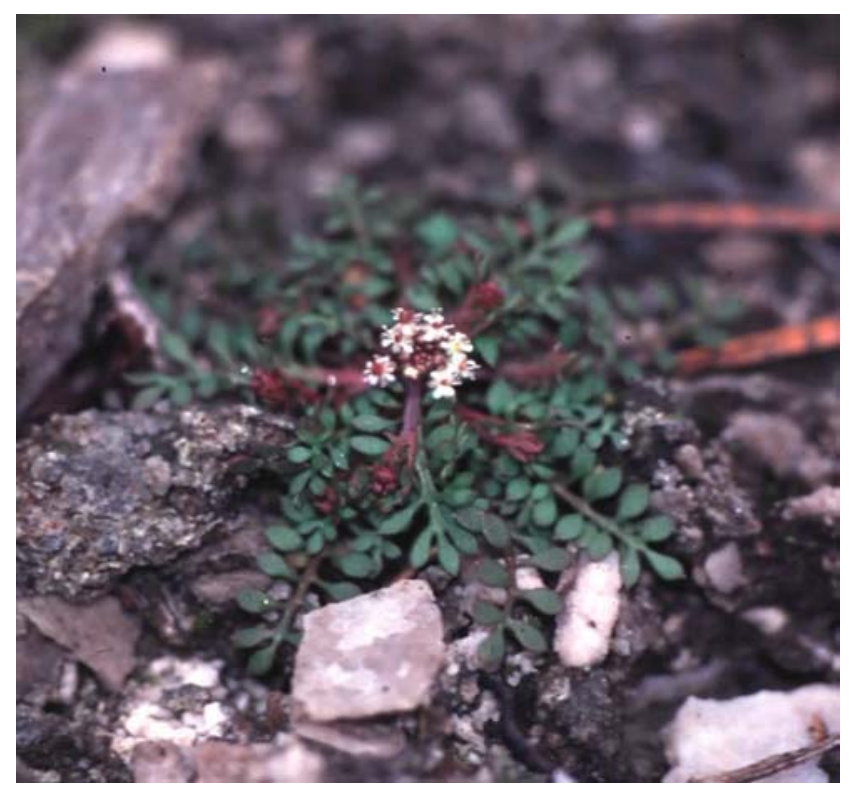

Abb. 1: Blühende Hornungia petraea im Februar 1999, Wüstes Kalktal bei Bad Frankenhausen. 
H. petraea ist von beachtlichem Interesse für den Naturschutz, da die Art als stark gefährdet auf der Roten Liste seltener Pflanzen Deutschlands geführt wird (Kategorie 2, Korneck et al. 1996). Zudem ist sie Charakterart der Alysso-Sedion Gesellschaften (Oberdorfer 1978), die innerhalb der Europäischen Union zu den prioritären Lebensraumtypen gehören (Natura 2000 Code 6110; European Council 1992). H. petraea hat eine submediterrran-subatlantische Verbreitung. Im Mittelmeerraum ist das Areal mehr oder weniger geschlossen, nach NordOsten zerfällt das Areal in einzelne Exklaven (Jalas \& Suominen 1996, Abb. 2). In Deutschland weist die Art vereinzelte Vorkommen bei Bad Dürkheim, im Nahetal, im Maintal bei Würzburg und im Süntel (Wesergebirge) auf. Eine größere Exklave erstreckt sich von Nordhausen in Thüringen bis fast nach Halle an der Saale (Sachsen-Anhalt, Haeupler \& Schönfelder 1989; Benkert et al. 1996).

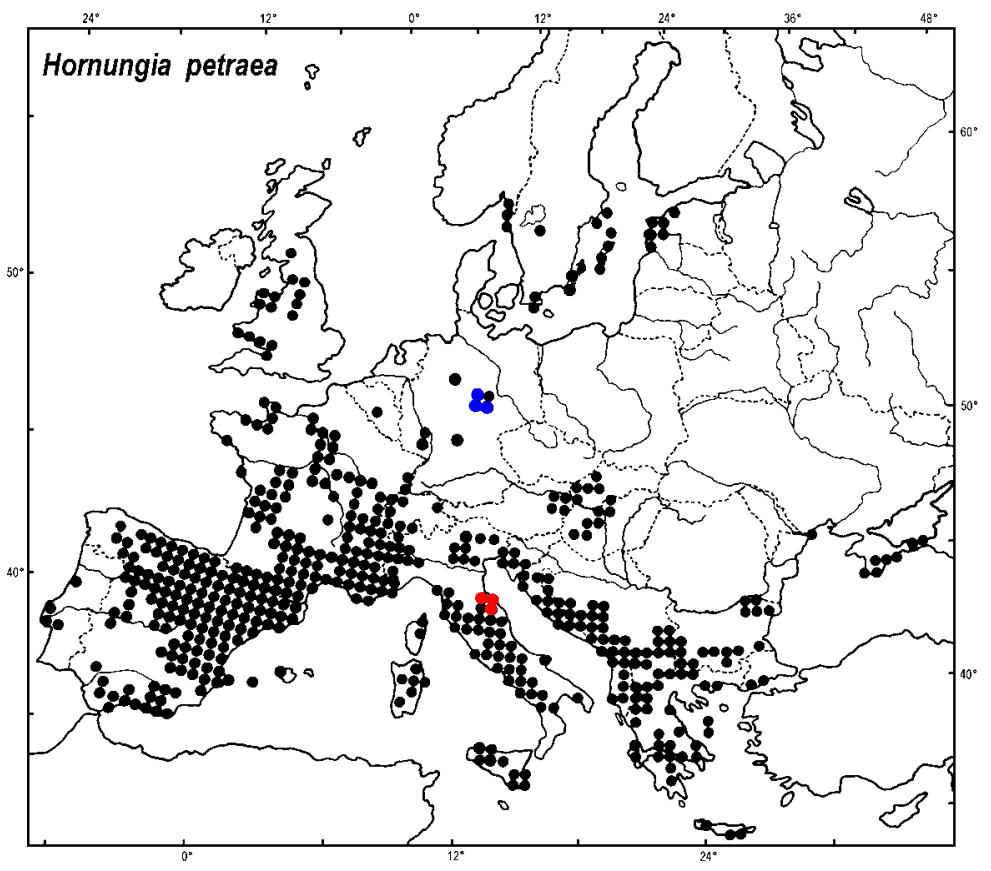

Abb. 2: Verbreitungskarte von Hornungia petraea (nach Jalas \& Suominen 1996). Die blauen und roten Punkte geben die Lage der Untersuchungsgebiete in Deutschland bzw. Italien an.

\section{Untersuchungsgebiet, Untersuchungsflächen und Beprobungsdesign}

Stellvertretend für zentrale und periphere Vorkommen von $H$. petraea wurden zwei Untersuchungsgebiete in Mittelitalien und Mitteldeutschland ausgewählt. Die italienischen Untersuchungsflächen lagen im Apennin der Regionen Marken und Umbrien. Das deutsche, periphere Untersuchungsgebiet erstreckte sich über die größte deutsche Exklave in den Bundesländern Thüringen und Sachsen-Anhalt (Abb. 2). In beiden Gebieten wurden entlang eines $100 \mathrm{~km}$ langen Transekts jeweils zehn H. petraea-Populationen als Untersuchungsflächen ausgewählt (Abb. 1, Kapitel 2). In beiden Ländern sollte durch die Flächenauswahl die gesamte standörtliche Amplitude der Art abgedeckt werden. In Deutschland wurde dieses 
Ziel erreicht, indem das Transekt entlang der gesamten Ost-West-Verbreitung der Art innerhalb der Exklave angelegt wurde. Die Höhenlage der Untersuchungsflächen in Deutschland lag zwischen 170 und $275 \mathrm{~m}$ ü. NN. In Italien wurde fast die gesamte Höhenamplitude der Art in diesem Gebiet abgedeckt, die Untersuchungsflächen lagen hier auf Höhen zwischen 280 und $1560 \mathrm{~m}$ ü. NN.

Da die von $H$. petraea-Populationen bedeckten Flächen von stark unterschiedlicher Größe und Form waren, wurde ein spezielles Beprobungsdesign entwickelt. Jede Untersuchungsfläche wurde anhand eines an die Flächengröße angepassten Gitters in 100 Gitternetzzellen unterteilt. Aus diesen 100 möglichen Probenahmeorten wurden zufällig zehn ausgewählt, auf denen Kleinquadrate (Subplots) von $30 \mathrm{~cm} * 30 \mathrm{~cm}$ etabliert wurden. Diese Subplots stellten in jeder Population die eigentlichen Untersuchungseinheiten für die Geländeuntersuchungen dar, und zwar sowohl für die Analyse der Diversitätsmuster (Kapitel 2) als auch für die demographischen Untersuchungen (Kapitel 3 und 4). Die erhobenen Daten sind damit doppelt ineinander verschachtelt: die Subplots in den untersuchten Populationen und diese wiederum in den Ländern. Für die demographischen Erhebungen wurden auf Subplot-Ebene Zählungen der Individuen von $H$. petraea von April 1999 bis Mai 2001 an insgesamt 15 Terminen durchgeführt. Mit einer geringeren zeitlichen Auflösung, jeweils vor und nach der Samenausbreitung, wurden Samenbankproben mit einem Stechzylinder von 5,5 cm Durchmesser und $4 \mathrm{~cm}$ Höhe in direkter Nachbarschaft zu den Subplots genommen und die Samenbankpopulationsdichten mittels eines Auskeimexperiments analysiert.

\section{Biodiversitätsmuster über verschiedene Skalenebenen}

In Kapitel 2 (Kluth \& Bruelheide 2004c) wird anhand des Vorkommens von H. petraea eine Untersuchung der Diversitätsmuster von Pflanzengesellschaften vorgenommen. Bei der Analyse der Biodiversität über mehrere Skalenebenen hinweg ergeben sich häufig Schwierigkeiten aus den meist unterschiedlichen Methoden der Beprobung der Artenvielfalt auf den unterschiedlichen Skalen. Ein weiteres Problem stellt die eindeutige Abgrenzung der zu untersuchenden Biozönose dar, in diesem Fall die Definition der zu untersuchenden Pflanzengesellschaft. Anhand des Vorkommens der Zielart H. petraea konnte der untersuchte Vegetationstyp - selbst über die große geographische Distanz zwischen Mitteldeutschland und Mittelitalien - eindeutig definiert werden. Das verwendete streng hierarchische Beprobungsdesign, das ursprünglich für die Analyse der Populationsstruktur von H. petraea entwickelt worden war, eignete sich auch bestens zur Analyse der Biodiversität auf verschiedenen Skalenebenen. Hierzu wurden Artenlisten sowohl für jeden Subplot als auch für jede gesamte 
Untersuchungsfläche erstellt. Ziel war es, gängige Diversitäts-Indices, die sowohl den Artenreichtum ( $\alpha$-Diversität, $\gamma$-Diversität) als auch eine Änderung der Artenzusammensetzung ( $\beta$-Diversität) betreffen, mit Indices zu vergleichen, die von Artenakkumulationskurven abgeleitet wurden. Den Artenreichtum betreffend sind dies für die betrachteten Skalen- bzw. Hierarchieebenen die Artenzahl pro Subplot (interne $\alpha$-Diversität), die Artenzahl pro Untersuchungsfläche ( $\alpha$-Diversität) und die Artenzahl aller Untersuchungsflächen im jeweiligen Land ( $\gamma$-Diversität). Ein Index, der die Änderung der Artenzusammensetzung beschreibt, ist die Unähnlichkeit (=1-Jaccardindex). Auf den verschiedenen Skalen sind dies im einzelnen die mittlere Unähnlichkeit zwischen den Subplots innerhalb einer Untersuchungsfläche (interne $\beta$-Diversität), die Unähnlichkeit zwischen den einzelnen Untersuchungsflächen innerhalb eines Landes ( $\beta$-Diversität) und die Unähnlichkeit zwischen den beiden Ländern. Verglichen wurden diese Indices mit den Schätzparametern, die sich aus der Anpassung der Artenakkumulationskurven der jeweils betrachteten Skalenebene an die Michaelis-Menten-Gleichung ergeben. Die zu erwartende Übereinstimmung der MichaelisMenten-Indices mit den gängigen Diversitäts-Indices wird hergeleitet. Des weiteren werden die Diversitäts-Indices verschiedener Skalen sowohl untereinander in Beziehung gesetzt als auch zu den Größen der Untersuchungsflächen, der geographischen Entfernung und der Höhenunterschiede zwischen den Untersuchungsflächen.

\section{Ergebnisse und Schlussfolgerungen}

Für die Artenzahl der Subplots bestand kein signifikanter Unterschied zwischen den deutschen und italienischen Untersuchungsflächen, aber sowohl die $\alpha$ - wie auch die $\gamma$-Diversität waren in Italien höher als in Deutschland. In Deutschland lagen dagegen die interne $\beta$ Diversität und die $\beta$-Diversität niedriger als in Italien. Die Unähnlichkeit nahm mit Zunahme des Skalenniveaus von der Ebene der Subplots über die Ebene der einzelnen Untersuchungsflächen bis hin zur Ebene der Regionen zu. Entsprechende Ergebnisse wurden durch die Berechnung der Schätzparameter der Michaelis-Menten-Gleichung über die Artenakkumulationskurven erreicht. Signifikant positive Korrelationen bestanden zwischen der internen $\alpha$ Diversität und der $\alpha$-Diversität in beiden Ländern, wohingegen interne $\beta$-Diversität und interne $\alpha$-Diversität nur für die italienischen Untersuchungsflächen eine Korrelation aufwiesen. Im deutschen Untersuchungsgebiet wurde eine Abnahme der Ähnlichkeit mit zunehmender Entfernung zwischen den Untersuchungsflächen gefunden. Dies traf nur in geringerem Ausmaß für die italienischen Untersuchungsflächen zu, bei denen die Höhenunterschiede zwischen den Untersuchungsflächen eine Rolle spielten. Durch das Beprobungs- 
design und die einheitliche Analyse der Artenakkumulationskurven anhand der MichaelisMenten-Gleichung konnten einheitliche Ergebnisse über die verschiedenen Skalenniveaus hinweg erzielt werden. Die spezifische Therophytenvegetation dieser Untersuchung spiegelte Diversitätsmuster wieder, die ähnlich in anderen Untersuchungen gefunden wurden, z.B. eine stärkere Unähnlichkeit in zentralen im Vergleich zu peripheren Habitaten und einen Trend zu zunehmendem Artenreichtum in Richtung abnehmender geographischer Breite. Eine asymptotische Sättigung des Artenreichtums wurde zwischen den verschiedenen Skalen nicht beobachtet. Allem Anschein nach lässt sich das Verhältnis zwischen Artenreichtum und Unähnlichkeit auf spezifischen Skalen über die absolute Artenzahl auf einem spezifischen Skalenniveau und die Vollständigkeit der Beprobung durch das Beprobungsdesign erklären.

Für das Untersuchungsobjekt selbst ergibt sich, dass erstens die Art auf dem kleinsten betrachteten Skalenniveau, dem der Subplots, im Arealzentrum ebenso viele direkt benachbarte Arten hat wie am Arealrand und zweitens auf dem Niveau gesamter Populationen im Arealzentrum mehr Arten vorkommen als am Arealrand. Drittens unterscheiden sich die italienischen Untersuchungsflächen in ihrer Artenzusammensetzung stärker voneinander als die deutschen Flächen. Das heißt, dass H. petraea im italienischen zentralen Untersuchungsgebiet in einer größeren Anzahl unterschiedlicher Habitate auftritt als im peripheren deutschen Untersuchungsgebiet.

\section{Zentrale und periphere Populationen: Muster und Dynamik}

In Kapitel 3 (Kluth \& Bruelheide 2004a) wird zunächst die Annahme des ,central-marginal model“ hinsichtlich der Dichten von Populationen in Arealzentrum bzw. am Arealrand für $H$. petraea geprüft. Dabei wurde auf alle Lebensstadien von $H$. petraea eingegangen. Im einzelnen sind dies die Dichte adulter, reproduktiver Pflanzen, die Samenproduktion (Fekundität) und die Samenbank sowohl vor als auch nach dem Ausstreuen der Samen im Frühling. Entsprechend dem verschachtelten und zeitlich wiederholten Beprobungsdesign wurde die Auswertung der Individuendichten bzw. der Fekundität mittels eines statistischen Modells (non-parametric nested repeated measures ANOVA) geprüft, das es erlaubt, die Einflussgrößen Land, Population und zeitliche Wiederholung korrekt und exakt zu behandeln und ihren jeweiligen Anteil an der erklärten Varianz im gesamten Datensatz abzuschätzen.

\section{Ergebnisse und Schlussfolgerungen}

Entgegen den Aussagen des „,entral-marginal model“ wiesen deutsche periphere Populationen im Vergleich zu zentralen italienischen Populationen höhere Individuendichten auf, 
und zwar sowohl hinsichtlich der Population adulter $H$. petraea-Pflanzen als auch der Samenbankpopulation. Die Fekundität hing stark vom Untersuchungsjahr ab und wurde nur in geringem Ausmaß von der Lage der Untersuchungsflächen innerhalb des Areals beeinflusst. Die starke interannuelle Dynamik der Fekundität spiegelte sich weder in der interannuellen Dynamik der Dichte adulter Pflanzen im Frühling noch in der interannuellen Dynamik der Samenbankpopulationen wider. Zwischen den zentralen und peripheren Untersuchungsflächen bestanden signifikante Unterschiede hinsichtlich der saisonalen Dynamik der Samenbankpopulationen. Die saisonale Dynamik der Samenbanken peripherer deutscher Populationen war stärker ausgeprägt als die zentraler italienischer Populationen. Daraus lässt sich folgern, dass die saisonale Dynamik der Samenbankpopulation von zentraler Bedeutung für die Erklärung der unterschiedlichen Dichtemuster von $H$. petraea ist. Dies gilt insbesondere für zentrale Populationen, die deutlich weniger Samen in die Samenbank inkorporierten als periphere Populationen.

Diese Ergebnisse, die sich aus der direkten empirischen Untersuchung aller Lebensstadien von $H$. petraea ergeben, widersprechen somit der zentralen Annahme über räumliche Muster der Populationsdichten, die sich aus dem „,central-marginal model“ ableiten. Damit liefert diese Untersuchung einen weiteren Hinweis darauf, dass ein dem „central-marginal model“ gegenläufiges Muster häufiger beobachtet werden könnte als generell angenommen.

\section{Übergangsraten zwischen Lebensstadien}

In Kapitel 4 (Kluth \& Bruelheide 2004b) wird auf die demographischen Gründe zur Erklärung des unerwarteten räumlichen Musters genauer eingegangen. Dabei werden die Übergangsraten zwischen Lebensstadien von $H$. petraea auf dem Skalenniveau ganzer Populationen betrachtet. Wachstumsraten von Pflanzenpopulationen werden entscheidend durch ihre Dichte reguliert. Bisherige Studien zu einer dichteabhängigen Selbstregulation von Populationen haben zumeist die Fekundität und die Überlebensraten innerhalb von Populationen untersucht. In diesem Abschnitt soll die Dichteabhängigkeit aller Lebensstadien von $H$. petraea inklusive der Keimrate und der Inkorporationsrate der Samen in die Samenbank auf der Skalenebene der gesamten Population untersucht werden. Neben der zu erwartenden Dichteabhängigkeit der Übergangsraten sollte der Einfluss des Untersuchungsgebiets und der zeitlichen Wiederholung berücksichtigt werden. Dem ,central-marginal model“ gemäß müsste erwartet werden, dass sich die Umweltbedingungen am Rand des Verbreitungsgebiets negativ auf die Übergangswahrscheinlichkeiten der Art auswirken und damit zu verringerten Populationsdichten führen. Darüber hinaus wäre aus dem ,central-marginal model“ eine höhere 
interannuelle Variation der Übergangsraten am Arealrand mit entsprechenden Effekten auf die Populationsdichten abzuleiten.

Da für das Untersuchungsobjekt ein zum „central-marginal model“ gegenläufiges Muster gefunden wurde (s. Kapitel 3), wurden die weiteren Hypothesen diesem neuen Erkenntnisstand angepasst. Ziel war es, mögliche demographische Ursachen für das Muster geringerer Populationsdichten im Arealzentrum aufzudecken. Im einzelnen wurde erwartet, dass erstens die Übergangsraten zwischen den verschiedenen Lebensstadien der Art bei vergleichbarer Dichte in den italienischen Populationen geringer ausfallen als bei den peripheren deutschen Populationen. Zweitens wurde erwartet, dass eine höhere interannuelle Variation der Übergangsraten im Arealzentrum zu finden sei. Hinsichtlich der dichteabhängigen Regulation der Populationen wurde erwartet, dass das Ausmaß der Dichteabhängigkeit in den dichteren deutschen peripheren Populationen höher sei als in den weniger dichten italienischen Populationen.

Um die Übergangsraten statistisch auszuwerten, wurde ein schrittweises Vorgehen in einer autoregressiven Kovarianzanalyse mit Messwiederholungen gewählt. Damit können die Effekte der einzelnen, die Übergangsraten beeinflussenden Faktoren kontrolliert und in einem einzigen statistischen Modell behandelt werden. Diese Faktoren sind die Dichte als Kovariable, das Untersuchungsgebiet, die jährliche Wiederholung sowie alle möglichen Interaktionseffekte dieser Faktoren.

\section{Ergebnisse und Schlussfolgerungen}

In den Untersuchungen konnten alle drei Ausgangshypothesen bestätigt werden, wobei jedoch zwischen den verschiedenen Übergangsraten zwischen Lebensstadien ein unterschiedlich großer Einfluss der Position im Areal, der Dichteabhängigkeit und der Variation zwischen den Jahren bestand. Die Keimrate und die Inkorporationsrate der Samen in die Samenbank waren stark dichteabhängig, und diese Übergangsraten unterschieden sich signifikant zwischen den beiden Ländern. Die zentralen italienischen Populationen wiesen eine höhere interannuelle Variation der Fekundität auf. Die einzige Übergangsrate mit höherer Dichteabhängigkeit in den peripheren Populationen war die Überlebensrate der Pflanzen im Winter.

Für die Mehrzahl der Übergangsraten wäre der Unterschied zwischen Verbreitungszentrum und Peripherie nicht zutage getreten, wenn die Dichteabhängigkeit der Übergangsraten und ihre interannuelle Variation nicht entsprechend im Modell berücksichtigt worden wären. Durch diese Analyse zeigt sich die Notwendigkeit, alle zu erwartenden Einflussgrößen auf die Übergangsraten in ein und dasselbe statistische Modell einzubeziehen. Diese Untersuchung 
zeigt zudem die Möglichkeiten auf, wie Felddaten, bei denen Dichte und interannuelle Variabilität nicht experimentell kontrolliert werden können, sinnvoll auszuwerten sind.

\section{Ausblick}

Neben den in dieser Arbeit beschriebenen demographischen Aspekten von H. petraea wurden in dem Gesamtprojekt zu H. petraea auch die anderen Glieder der aus dem ,central-marginal model“ abgeleiteten Kausalkette untersucht. Diese Untersuchungen sind bereits abgeschlossen, haben hier jedoch noch keinen Eingang gefunden. Wenig beachtet wurden in der Literatur bisher die standörtlichen Witterungsbedingungen, die als Ursache einer Reduktion der Populationsdichten angeführt werden. Für H. petraea wurden die autökologischen Ansprüche der zentralen und peripheren Populationen an Keimungs- und Wachstumsbedingungen in Klimaschränken untersucht. Wie im Gelände hatten italienische Herkünfte auch unter einheitlichen Bedingungen niedrigere Keimraten als deutsche Herkünfte. Die Temperaturbedürfnisse für die Keimung und Samenproduktion differenzierten die Herkünfte sowohl nach Land als auch nach Population. Entsprechend sind die untersuchten Herkünfte als genetisch differenziert zu erachten. Wurden die aus den Daten der Klimaschrankexperimente ermittelten optimalen Temperatur- und Bodenfeuchtebedingungen mit den im Gelände tatsächlich vorgefundenen und mittels automatischer Wetterstationen erhobenen mikroklimatischen Bedingungen verglichen, so waren die mikroklimatischen standörtlichen Bedingungen bezüglich Wachstum und Keimung entsprechend dem „central-marginal model“ im Arealzentrum als günstiger zu bewerten. Der Vergleich der demographischen Erhebungen mit den Mikroklimamessungen zeigte jedoch für die nicht dichteregulierte Winterüberlebensrate im italienischen Untersuchungsgebiet einen signifikanten Zusammenhang mit der Anzahl der Frostwechseltage.

Ebenfalls wurden in dem Projekt molekulargenetische Analysen mittels AFLP-Markern für die demographisch und autökologisch untersuchten Populationen von $H$. petraea durchgeführt. Die Auswertung dieser Daten steht zwar noch aus, jedoch haben die in der vorliegenden Arbeit vorgestellten Ergebnisse Einfluss auf die Erwartungen zur genetischen Struktur der Populationen von H. petraea. Erstens legt die höhere Anzahl unterschiedlicher von $H$. petraea besiedelter Habitate in Italien den Schluss nahe, dass die genetische Diversität zwischen den italienischen Populationen größer ist als die zwischen den deutschen Populationen. Zweitens kann erwartet werden, dass die geringeren Populationsdichten in Italien die genetische Varianz innerhalb der Populationen verringern. Drittens führt jedoch die höhere Meta-Populationsdynamik im italienischen Untersuchungsgebiet zu einem höheren 
genetischen Austausch zwischen den Populationen. Derartige Zusammenhänge zeigen die Wichtigkeit der Implementierung demographischer Gegebenheiten für das „central-marginal model“" und könnten damit auch erklären, warum sich eine reduzierte molekulargenetische Varianz am Arealrand bisher nicht als generelles Muster hat bestätigen lassen. 


\section{Using standardised sampling designs from population ecology to assess biodiversity patterns of therophyte vegetation across scales}

\section{Abstract}

Aim The analysis of diversity across multiple scales is hampered by methodological difficulties resulting from the use of different sampling methods at different scales and by the application of different definitions of the communities to be sampled at different scales. It is our aim to analyse diversity in a nested hierarchy of scales by applying a formalized sampling concept used in population ecology when analysing population structure. This concept involved a precise definition of the sampled vegetation type by the presence of a target species, in our case Hornungia petraea. We compared separate indices of inventory diversity (i.e. number of species) and differentiation diversity (i.e. extent of change in species composition or dissimilarity) with indices derived from species accumulation curves and related diversity patterns to topographical plot characteristics such as area and distance.

Location Ten plots were established systematically over a distance of $100 \mathrm{~km}$ each in the distribution centre of $H$. petraea in Italy (i.e. Marche and Umbria) and in a peripheral exclave in Germany (i.e. Thuringia and Saxony-Anhalt).

Methods We used a nested sampling design of ten random subplots within plots and ten systematically placed plots within regions. Internal $\alpha$-diversity (species richness) and internal $\beta$-diversity (dissimilarity) were calculated on the basis of subplots, $\alpha$-, $\beta$ - and $\gamma$-diversity on the basis of plots in Italy and Germany. In addition, indices of inventory diversity and differentiation diversity were derived by fitting species accumulation curves to the MichaelisMenten equation.

Results There was no significant difference in the internal $\alpha$-diversity between German and Italian plots but the $\alpha$ - and $\gamma$-diversity were higher in Italy than in Germany. In Germany, the internal $\beta$-diversity and $\beta$-diversity was lower than in Italy. The differentiation diversity increased with increasing scale from subplots over plots to regions. The same results were obtained by calculating species accumulation curves. Significant positive correlations were encountered between the internal $\alpha$-diversity and $\alpha$-diversity in both countries, while the internal $\beta$-diversity and internal $\alpha$-diversity showed a correlation only for the Italian plots. Similarity decay was found for German plots with respect to inter-plot distance and for Italian plots with respect to altitudinal difference and to a smaller degree to distance between plots. 
Main conclusions The design chosen and the consistent analysis of species accumulation curves by the Michaelis-Menten equation yielded consistent results over different scales. The specific therophyte vegetation type in this study reflected diversity patterns also observed in other studies, e.g. a greater differentiation diversity in central than in peripheral habitats and a trend of increasing species richness towards lower latitudes. No asymptotic saturation of species richness between different scales was observed. Indications were found that the absolute level of inventory diversity at a particular scale and the completeness of the sampling procedure are the main clues for explaining the relationship between inventory and differentiation diversity at this particular scale.

Keywords Differentiation diversity, diversity relationships, Hornungia petraea, MichaelisMenten, nested sampling design, similarity decay, species accumulation, species richness.

\section{Introduction}

Biodiversity can be studied in nature over a wide range of scales corresponding to different hierarchical levels (e.g. Wagner et al. 2000; Crawley \& Harral 2001; Whittaker et al. 2001; Gering \& Crist 2002; Willis \& Whittaker 2002). These levels are traditionally referred to as $\alpha$-, $\beta$-, and $\gamma$-diversity, although more levels can be considered below the $\alpha$ - or above the $\gamma$ niveau (Whittaker 1977). Since publication of Whittaker's paper in 1972 it is a much disputed point as to whether general relationships exist between the different hierarchical levels and whether these relationships have a linear or asymptotic form (Huston 1999; Lawton 1999; Loreau 2000). Theory suggests that a positive relationship is expected between $\alpha$ - and $\gamma$ diversity (Lawton 1999; Loreau 2000). This is supported by most observations (Caley \& Schluter 1997; Srivastava 1999; Cornell 1999). However, $\alpha$-diversity has also been observed to be independent of $\gamma$-diversity, so called Type II or saturation relationships (Cornell \& Lawton 1992; Richardson et al. 1995; Cornell \& Karlson 1997; Srivastava 1999; Cornell 1999). This is generally explained by the assumption of local interactions between species (Cornell \& Lawton 1992; Richardson et al. 1995). In contrast, Schoolmaster (2001) showed that the asymptotic form can be predicted also without local interactions and Cornell (1999) supposed that saturation might be an artefact of overestimating regional species richness. Loreau (2000) argued that the type of relationship depends on the scale at which a community is defined. In particular, comparison of plant communities involves different scales because of the different plot sizes used to define a community. In addition, differences in vegetation types are inevitably coupled with differences in underlying site factors (Srivastava 1999), also in those factors that, according to existing theories, exert dominant influence on diversity, e.g. 
productivity and disturbance (Huston 1979; 1994; 1999). It is generally assumed that $\gamma$ diversity can be partitioned into $\alpha$ - and $\beta$-components (Loreau 2000; Wagner et al. 2000; Gering \& Crist 2002). From the assumption of a positive relationship between $\alpha$ - and $\gamma$ diversity outlined above an independent relationship would be expected between $\alpha$ - and $\beta$ diversity. However, empirical studies have also detected negative relationships, e.g. Pärtel et al. (2001) in alvar grasslands in Estonia.

The usual approach in biodiversity studies is to confine the investigation to specific vegetation types, e.g. to forests (Condit et al. 1996; Qian et al. 1998), or to alvar grasslands (Sykes et al. 1994; Pärtel et al. 2001) or to specific land uses (Rescia et al. 1997). However, even this restriction still allows for a considerable variation in other factors because recordings made at different scales have to be compared (e.g. plot scale for $\alpha$-diversity in relation to regional scale for $\gamma$-diversity). We chose a vegetation type dominated by therophytes in patches of open ground in calcareous grasslands as a study object that could be very narrowly defined even across scales. This was achieved by using the presence of a species with a narrow ecological amplitude as a definition criterion for the vegetation type. This species was Hornungia petraea (L.) RCHB., a tiny winter therophyte of the Brassicaceae. $H$. petraea is restricted to this type of gap habitats throughout its geographical distribution range. Sociologically, this thus-defined therophyte vegetation belongs to the Alysso-Sedion (Oberdorfer 1978), which is a priority habitat type in the EU (Natura 2000 Code 6110; European Council 1992). In addition, H. petraea is a rare species and listed in the German Red Data Book as endangered (category 2; Korneck et al. 1996). This had the advantage of reducing the number of locations from which study sites had to be selected.

The plots used in this study had initially been selected and established for a study on the population ecology of $H$. petraea (Kluth \& Bruelheide unpubl.). In this study a highly standardised hierarchical sampling scheme was designed to select individuals for monitoring growth and reproduction as well as for sampling individuals for autecological experiments and genetic analysis. One might argue that studying vegetation diversity on these plots which had been selected from the perspective of population ecology cannot be more than a by-product. On the contrary, we consider this to be rather an advantage because it guarantees a consistent study design. The nested sampling concept used in population ecology for analysing population structure (Wright 1921; Hartl \& Clark 1997) provides an optimal framework for studying diversity patterns across scales. First, local diversity patterns can be studied by recording all species on subplots within $H$. petraea populations. This corresponds 
to subplot species richness, called internal $\alpha$-diversity by Whittaker (1977), whose terminology is followed throughout this paper. Second, between-subplot differentiation can be assessed by calculating dissimilarity between subplots (internal $\beta$-diversity). Third, recordings on the area covered by a given $H$. petraea population corresponds to plot species richness $(\alpha-$ diversity). Fourth, comparing different plots results in between-plot differentiation ( $\beta$ diversity; dissimilarity between plots). Fifth, the total number of species found in all plots of one of our two study regions correspond to regional species richness ( $\gamma$-diversity). On this level, we have confined our study to only two regions: the distribution centre in Italy and the periphery of the distribution range of $H$. petraea in Germany. These regions also represent central and marginal variants of the corresponding therophyte vegetation type. Sixth and finally, concordance in species composition can be calculated for the studied therophyte grasslands between the two study regions. Level 1, 3 and 5 describe inventory diversity (i.e. number of species) and 2, 4 and 6 differentiation diversity (i.e. change of composition or dissimilarity, Whittaker 1977).

Traditional comparisons across these levels often use data from different studies that show a large methodological variation, e.g. in subjective versus random plot selection (Mawdsley 1996; Srivastava 1999). By using population ecological sampling designs such methodological variation can be reduced to a minimum with simple selection criteria (i.e. presence of the study species). Astonishingly, only very few diversity studies have defined their target by the occurrence of a single species. For example, Qian et al. (1998) investigated diversity of black and white spruce stands (Picea mariana and P. glauca) in North American boreal forest along a longitudinal gradient over the species' entire distribution range.

Inventory and differentiation diversity can either be calculated directly from subplot and plot data or can be derived from species accumulation curves. There are several options available to fit approximations to the resulting curves (see Colwell \& Coddington 1994). Despite the criticism on the Michaelis-Menten equation (Keating \& Quinn 1998) it has meaningful estimation parameters both for inventory diversity and differentiation diversity (Raaijmakers 1987; Colwell \& Coddington 1994).

Apart from comparing diversity levels, diversity studies aim at explaining observed patterns by plot characteristics, such as plot's area or inter-plot distance. A positive relationship between $\alpha$-diversity and the plot's area is generally expected (e.g. Preston 1960; MacArthur \& Wilson 1967; Shmida \& Wilson 1985; Condit et al. 1996; Crawley \& Harral 2001). Dispersal limitation, environmental dissimilarity or simply spatial autocorrelation lead to a 
distance-dependent decay of similarity between plots (e.g. Qian et al. 1998; Nekola \& White 1999; Condit et al. 2002).

The main objective of this paper is to analyse diversity in a nested hierarchy of scales but at the same time to reduce the variation due to vegetation type definition to a minimum. We further aim at comparing separate diversity indices with indices derived from a single calculation, i.e. from species accumulation curves using the Michaelis-Menten equation. Our third objective was to relate the diversity results to topographical plot characteristics such as area and inter-plot distance.

\section{Material and Methods}

\section{Field sampling}

Hornungia petraea has a submediterranean-subatlantic distribution which is more or less continuous in the Mediterranean region but disintegrates into patches towards Central and Northern Europe. In Central Germany, H. petraea is found in an exclave where the species reaches its north-eastern distribution limit in Central Europe. In Central Germany and Central Italy, transects of about $100 \mathrm{~km}$ length were set up (Fig. 1). Ten plots along each transect were chosen on basis of the occurrence of populations of $H$. petraea. The distances between the plots were similar in the two countries ranging from $0.3 \mathrm{~km}$ to $86 \mathrm{~km}$ in Germany and from $1 \mathrm{~km}$ to $106 \mathrm{~km}$ in Italy with median values of 29 and $37 \mathrm{~km}$ in Germany and Italy, respectively. In Germany, the exclave's whole west-east gradient was included. In Italy, the transect was set up along the Apennine. It covered nearly the complete altitudinal range of $H$. petraea with plot elevations ranging from 280 to $1560 \mathrm{~m}$ a.s.1. (Tab. 1). In both Germany and Italy the plots had mainly southern aspects with considerable inclination (Tab. 1). A particular design for recording species composition of a plot had to be developed to account for the varying plot area and plot shape. The plot area varied because a plot corresponded to the entire area covered by a $H$. petraea population, defined as the area continuously covered by the species and limited by the lack of occurrence of individuals over a distance of several meters. In general, the limit of the population coincided with a change in vegetation structure from open and bare areas to more dense plant cover and a clear drop in density of $H$. petraea individuals. An advantage of using a target species for defining vegetation plots is the well defined plot size. It ranged between 4.3 to $988.5 \mathrm{~m}^{2}$ (Tab. 1). Each plot area was divided in 100 squares by using a grid adapted to plot size (for example see Fig. 2). These 100 squares represented possible sampling positions, out of which ten were randomly selected. Subplots of 
$30 \mathrm{~cm} * 30 \mathrm{~cm}$ were established and marked permanently. Species composition was recorded twice, in spring and summer 1999 and data were combined for analyses. In addition to subplot records, complete species lists were made for the entire plots. Plot D8 in Germany was abandoned because it had been severely disturbed by vandalism before the vegetation record could be completed. This resulted in nine German and ten Italian plots and a total of 190 subplots.
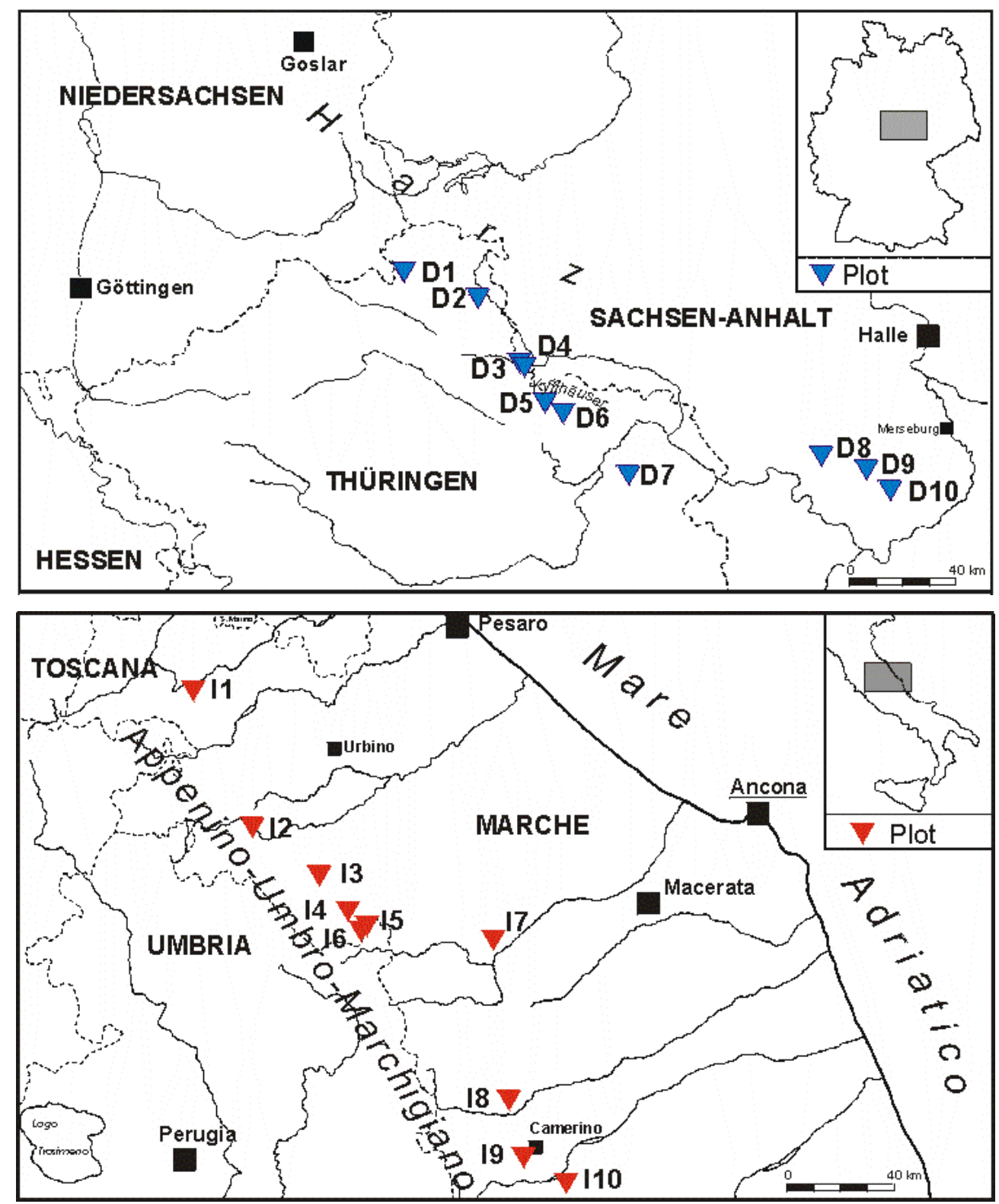

Fig. 1: Study areas in Germany (a) and Italy (b). $\mathbf{\nabla}$ : Location of studied Hornungia petraea plots. The plot notation are numbers from one to ten (north-west to south-east) prefixed with the country code (Germany D, Italy I). 
Tab. 1: Overview of the studied 19 Hornungia petraea population plots in Germany (D) and Italy (I). Aspect, slope and vegetation cover are the median values of 10 subplots. Vegetation cover is from the first relevé in spring 1999 when $H$. petraea plants were still green.

\begin{tabular}{|c|c|c|c|c|c|c|c|c|c|}
\hline Plot & Location & $\begin{array}{l}\text { Federal } \\
\text { state/region }\end{array}$ & $\begin{array}{l}\mathrm{E} \\
{\left[{ }^{\circ}\right]}\end{array}$ & $\begin{array}{l}\mathrm{N} \\
{\left[{ }^{\circ}\right]} \\
\end{array}$ & $\begin{array}{l}\text { Aspect } \\
\left.{ }^{\circ}\right]\end{array}$ & $\begin{array}{l}\text { Slope } \\
{\left[{ }^{\circ}\right]}\end{array}$ & $\begin{array}{l}\text { Altitude } \\
{[\mathrm{m} \text { a.s.1.] }}\end{array}$ & $\begin{array}{l}\text { Population } \\
\text { area }\left[\mathrm{m}^{2}\right]\end{array}$ & $\begin{array}{l}\text { Vegetation cover } \\
{[\%]}\end{array}$ \\
\hline D1 & Lochmühle, Woffleben & Thuringia & 10.70 & 51.56 & 255 & 40 & 245 & 34.4 & 25 \\
\hline D2 & Singerberg, Steigerthal & Thuringia & 10.88 & 51.53 & 145 & 20 & 275 & 24.2 & 20 \\
\hline D3 & Mittelberg, Auleben & Thuringia & 10.97 & 51.42 & 180 & 30 & 190 & 539.1 & 25 \\
\hline D4 & Schloßberg, Auleben & Thuringia & 10.98 & 51.42 & 305 & 35 & 200 & 74.9 & 40 \\
\hline D5 & Breiterberg, Rottleben & Thuringia & 11.05 & 51.36 & 180 & 20 & 180 & 349.8 & 25 \\
\hline D6 & Wüstes Kalktal, Bad Frankenhausen & Thuringia & 11.10 & 51.38 & 165 & 40 & 210 & 461.1 & 10 \\
\hline D7 & Kahle Schmücke, Harras & Thuringia & 11.22 & 51.27 & 230 & 20 & 255 & 8.6 & 25 \\
\hline D9 & Spittelsteingraben, Mücheln & Saxony-Anhalt & 11.78 & 51.29 & 210 & 30 & 170 & 91.3 & 20 \\
\hline D10 & Kuhberg, Gröst & Saxony-Anhalt & 11.83 & 51.26 & 190 & 10 & 175 & 4.3 & 30 \\
\hline I1 & Pietrarubbia, Mercato Vecchio & Marche & 12.39 & 43.79 & 315 & 25 & 740 & 25.5 & 10 \\
\hline $\mathrm{I} 2$ & Rio Vitoschio, Piobbico & Marche & 12.46 & 43.58 & 270 & 40 & 375 & 100.1 & 40 \\
\hline $\mathrm{I} 3$ & La Roccaccia, Cagli & Marche & 12.61 & 43.51 & 120 & 30 & 1020 & 955.9 & 15 \\
\hline I4 & Mt. Catria, $140 \mathrm{~m}$ below the summit & Marche & 12.70 & 43.46 & 240 & 30 & 1560 & 46.9 & 35 \\
\hline I5 & Rif. Boccatore, Mt. Catria & Umbria & 12.71 & 43.44 & 230 & 30 & 1190 & 988.5 & 40 \\
\hline I6 & Rif. Casa Strada, Chiaserna & Marche & 12.70 & 43.43 & 210 & 30 & 590 & 16.9 & 30 \\
\hline I7 & Gola della Rossa, Falcioni & Marche & 12.99 & 43.43 & 200 & 30 & 280 & 9.7 & 25 \\
\hline I8 & Pioraco & Marche & 13.00 & 43.18 & 245 & 5 & 400 & 25.6 & 30 \\
\hline I9 & Colle Lungo, Camerino & Marche & 13.02 & 43.11 & 120 & 10 & 700 & 68.8 & 60 \\
\hline $\mathrm{I} 10$ & Valone di Vescia, Fiastra & Marche & 13.18 & 43.04 & 230 & 20 & 875 & 751.0 & 25 \\
\hline
\end{tabular}

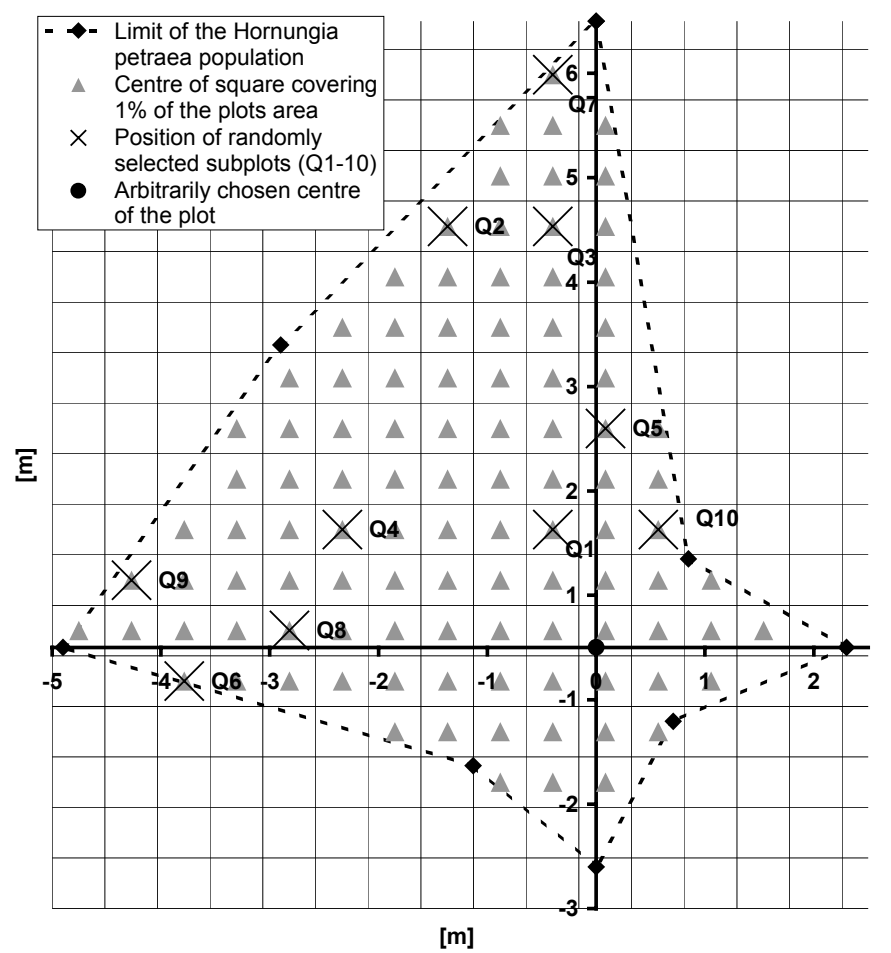

Fig. 2: Subplot selection within a Hornungia petraea plot, exemplified by the German plot D2. The plots were delimited by the continuous occurrence of $H$. petraea. Grid size was adopted to the plots' area such a way that the octagon comprised 100 grid cells.

\section{Data analysis}

For data analysis a broad species concept was applied by lumping several subspecies and microspecies to the same taxa (e.g. Festuca ovina s.1., F. pallens and F. inops, or Plantago lanceolata and $P$. argentea were combined). Species richness was assessed as species number per subplot $\left(0.09 \mathrm{~m}^{2}\right)$ and as species number per plot including species from all subplots and all additional species found on the plot. 


\section{Dissimilarity index}

Dissimilarity $(D S)$ between subplots in each plot was calculated by 1 - similarity $(S I)$ using Jaccard's index (Jaccard 1912; Magurran 1988) as a measure for similarity:

$$
D S_{i, j}=1-S I_{i, j}=1-\frac{c}{a+b-c}
$$

In equation $1, c$ refers to the number of common species of subplot or plot $\mathrm{i}$ and $\mathrm{j} ; a$ and $b$ refer to the total species number in subplot or plot $i$ and $j$, respectively. The median dissimilarity value of all resulting 45 comparisons between the ten subplots was taken as a measure of internal $\beta$-diversity for each plot. Correspondingly, the median value of all pairwise comparisons between plots in the same region (i.e. Germany or Italy) was considered to be $\beta$-diversity for each plot.

\section{$\underline{\text { Species accumulation }}$}

Species accumulation curves were calculated from species number in subplots for within-plot species accumulation and from total species number in plots for within-region accumulation. Subplots and plots were randomly re-ordered 1000 times using the EstimateS computer program (Version 6.0b1; Colwell 1997). Species richness (S) was then fitted to the MichaelisMenten equation (eq. 2).

$$
S(x)=\frac{a x}{b+x}
$$

In this equation, the estimated parameters have a direct meaning in terms of diversity: $x$ is the number of subplots or plots and $a$ is an estimator for inventory diversity (i.e. for $\alpha$-diversity of plots when cumulative subplot species richness is plotted against cumulative number of subplots, or for $\gamma$-diversity when cumulative plot species richness is plotted against cumulative number of plots; Raaijmakers 1987; Keating \& Quinn 1998; Kikvidze 2000). The estimator $b$ describes the sampling effort required to exactly observe half of the inventory diversity (i.e. of the asymptote value $a$ ) and has the same unit as $x$ (number of subplots or plots). In addition, $b$ is reciprocally proportional to the initial slope $k$ of the accumulation curve. This can be shown by computing the first derivative (eq. 3 ) at $\mathrm{x}=0$ (eq. 4 ):

$$
\begin{aligned}
& \frac{d S}{d x}=S^{\prime}(x)=\frac{a b}{(b+x)^{2}} \\
& S^{\prime}(0)=k=\frac{a}{b}
\end{aligned}
$$


From equation 4, the initial slope of species accumulation $k$ in relation to total number of species $a$ can be expressed as $1 / b$. Thus, $1 / b$ is an index of similarity between subplots or plots and $b$ is an index of dissimilarity and $\beta$-diversity. For example, if a plot has a small internal $\beta$ diversity (corresponding to a small $b$, a large $1 / b$ and therefore to a steep initial slope $k$ ) the asymptotic species richness of the plot $a$ is reached with only few subplots because these subplots contain a large portion of all of the plot's species.

The most important feature of the Michaelis-Menten equation is that all diversity levels are linked by this equation: internal $\alpha$-diversity $(=S(1))$, internal $\beta$-diversity $(=b)$ and $\alpha$-diversity $(=a)$ in the case of subplot species accumulation and $\alpha$-diversity $(=S(1)), \beta$-diversity $(=b)$ and $\gamma$-diversity $(=a)$ in the case of plot species accumulation.

\section{$\underline{\text { Similarity decay }}$}

Similarity decay can be described using the exponential model of equation 5 (Qian et al. 1998):

$$
\operatorname{SI}(d)=S I(0) e^{-c d}
$$

In equation $5, S I$ is the similarity at the distance $d, S I(0)$ is the initial similarity and $c$ is a constant for the rate of similarity decay. The rate of decay $c$ is identical with the slope of $\ln (S I)$ with distance $d$.

\section{Test statistics}

All calculated parameters were tested for normal distribution (proc univariate, Shapiro-Wilkstatistics, SAS Institute 2000a). Since some parameters were not normally distributed, we used a non-parametric statistic (rank score test, Brunner et al. 1999) with subsequent post hoc tests (Scheffé) for all sinysgle pairwise comparisons among the 19 plots (proc rank, proc mixed, SAS Institute 2000a, b). The same rank score test statistic was used for the comparison of median values of plots between regions (Germany and Italy). In all tests the significance level was $\alpha=0.05$.

All correlations were compared between Germany and Italy by using the confidence limits of the regression coefficients of either linear or non-linear regressions (eq. 2, eq. 5, proc nlin, proc corr, SAS Institute 2000a, b). Regressions were considered significantly different if the confidence limits did not overlap. If regressions between countries proved not to be significantly different, another regression was calculated using the pooled data of both countries. Regressions with pooled data are presented only when their probability of a type I 
error was smaller than the p-values of both country regressions. In general, Pearson's $\left(r^{2}\right)$ correlation was computed. For data that were not normally distributed Spearman's $\left(\mathrm{r}_{\mathrm{s}}{ }^{2}\right)$ rank correlation was calculated. Nevertheless, figures also show parametric regression lines for non-normally distributed data (see Fig. 7, 8, 9).

\section{Results}

Species richness of subplots, plots and regions

A total of 238 species were found in the 190 subplots; 92 of these were confined to Germany, 181 to Italy, and 35 species were common to both countries. The species richness of subplots (internal $\alpha$-diversity) varied considerably within and between plots (Fig. 3). Both the lowest and highest species number in any of all subplots were found in Italy, the number ranged from three species to 24 species. The subplot species richness differed significantly between plots $\left(\mathrm{F}_{18,171}=22.2, \mathrm{p}<0.001\right)$. Among the German plots, $17 \%$ of all possible pairwise comparisons between plots were significant; whereas among the Italian plots $29 \%$ were significant. A total of $37 \%$ of all pairwise plot comparisons between the two countries were significant. Nevertheless, there was no significant difference in the plot median values of subplot species richness between Germany and Italy $\left(F_{1,18}=2.41, p=0.140\right)$.

On the plot level ( $\alpha$-diversity) there were significantly more species in Italian plots than in German ones $\left(\mathrm{F}_{1,18}=18.3, \mathrm{p}<0.001\right)$. In total, we recorded 341 species within all plots, 134 of which were confined to Germany, 260 to Italy, and 53 species were common to both countries. Consequently, regional species richness ( $\gamma$-diversity) was lower in Germany than in Italy. On average, the plot species richness amounted to $20 \%$ of regional species richness.

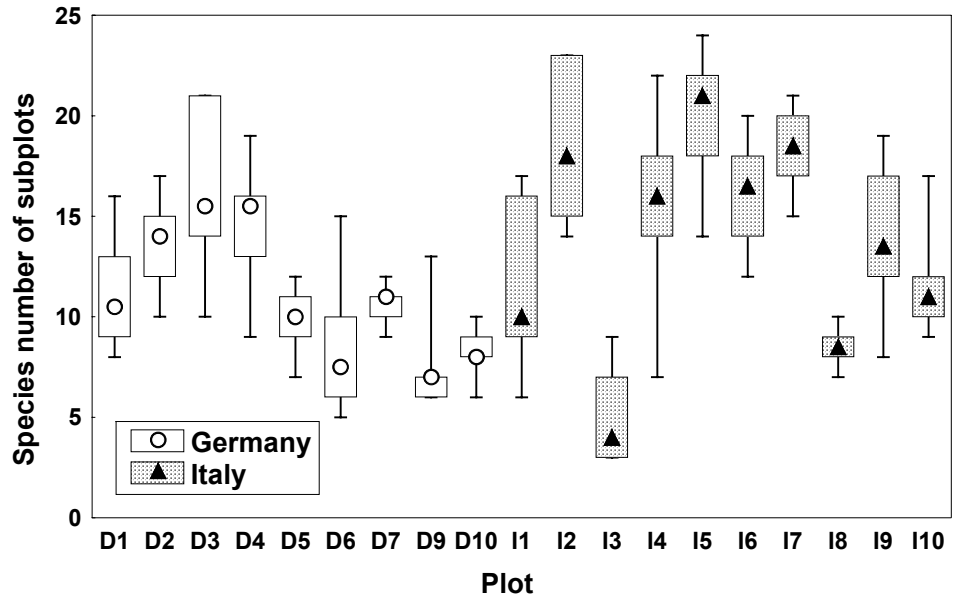

Fig. 3: Species richness of subplots $\left(0.09 \mathrm{~m}^{2}\right)$ for German and Italian plots $\left(\mathrm{F}_{18,171}=22.2, \mathrm{p}<0.001\right)$. Box-Whisker plots with median, 25 and $75 \%$ quantiles and extremes. 
Other than H. petraea, Arenaria serpyllifolia was the only species that occurred in all German and Italian plots. The most common species which exhibited a presence degree of $40 \%$ or more in both countries were the grasses Festuca ovina agg. and Bromus erectus, the perennial forb Sanguisorba minor and the therophyte Cerastium pumilum. Species with a presence degree of more than $50 \%$ in one country and absent in the other one were Euphorbia cyparissias, Acinos arvensis and Koeleria macrantha in Germany, and Sedum reflexum, S. album, Galium lucidum agg., Eryngium amethystinum, Minuartia hybrida and Satureja montana in Italy.

\section{Dissimilarity between subplots, plots and regions}

The dissimilarity between subplots within a plot (internal $\beta$-diversity) varied between 0 and 1 , which means that either some subplots had no species in common or that species composition of two subplots was identical (Fig. 4). The plots differed significantly in dissimilarity between subplots $\left(\mathrm{F}_{18,836}=42.0, \mathrm{p}<0.001\right)$. Nearly half $(48 \%)$ of all pairwise plot comparisons between the two countries were significant. In Germany $44 \%$ of all possible pairwise comparisons were significant, whereas in Italy the percentage was only $31 \%$. In general, German plots had a lower dissimilarity between subplots than Italian plots $\left(\mathrm{F}_{1,17}=8.38\right.$, $\mathrm{p}=0.011)$.

Dissimilarity between plots ( $\beta$-diversity) ranged from 0.53 between two German plots to 0.98 between a German and an Italian plot. The lowest dissimilarity between plots of different countries was 0.84 . In general, dissimilarity between German plots was significantly lower (median 0.76) than in Italy (median 0.79, $\mathrm{F}_{1,18}=28.6, \mathrm{p}<0.001$ ).

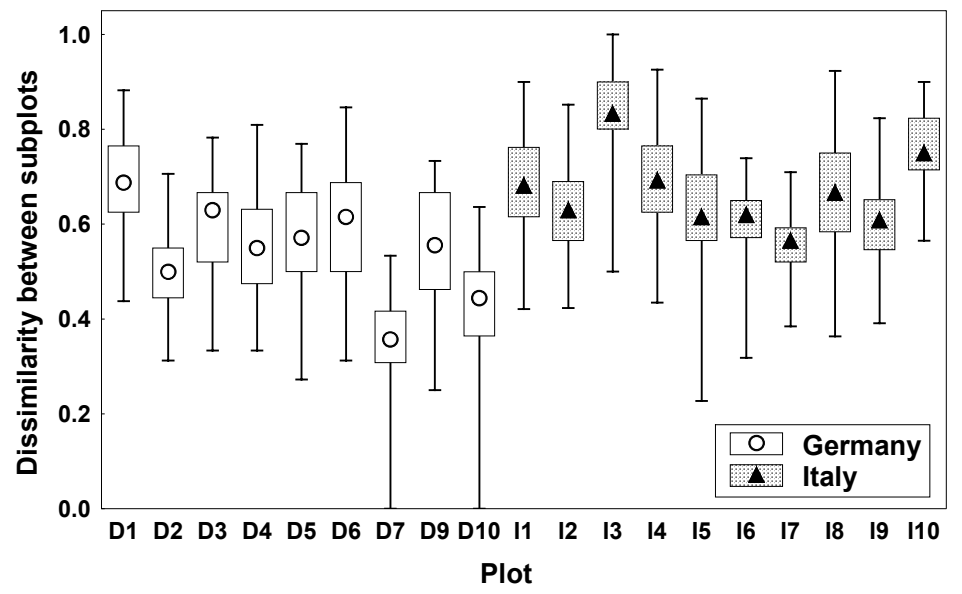

Fig. 4: Dissimilarity (1-Jaccard) between subplots for German and Italian plots, calculated as median dissimilarity of all pairwise comparisons between subplots $\left(\mathrm{F}_{18,836}=42.0, \mathrm{p}<0.001\right)$. Box-Whisker plots with median, 25 and $75 \%$-quantiles and extremes. 
On the region level, based on the total species list of both regions, a dissimilarity value of 0.84 was calculated between the two countries (differentiation diversity between regions).

Summarizing, the differentiation diversity increased with increasing scale from subplots $(D S=0.61)$ over plots $(D S=0.78)$ to regions $(D S=0.84)$.

\section{Species accumulation curves}

Fig. 5 shows the modelled within-plot species accumulation curves of all plots. Each curve is based on all subplots within a plot. In general, the data approximation by the MichaelisMenten equation was very good: $r^{2}$ ranged from 0.9894 to 0.9999 . The species accumulation curves reflected the results for $\alpha$-diversity as obtained directly from the plot data. The estimated asymptotic species richness $a$ was tightly correlated with the plot species number (Pearson's $\mathrm{r}^{2}=0.644, \mathrm{p}<0.001, \mathrm{n}=19$ ). The slope of the regression was not significantly different from 1.0, and the intercept was not significantly different from 0 . The estimated asymptotic species richness $a$ was significantly higher in Italy (median 53.1) than in Germany (median 31.5, $\mathrm{F}_{1,18}=14.0, \mathrm{p}=0.002$ ).

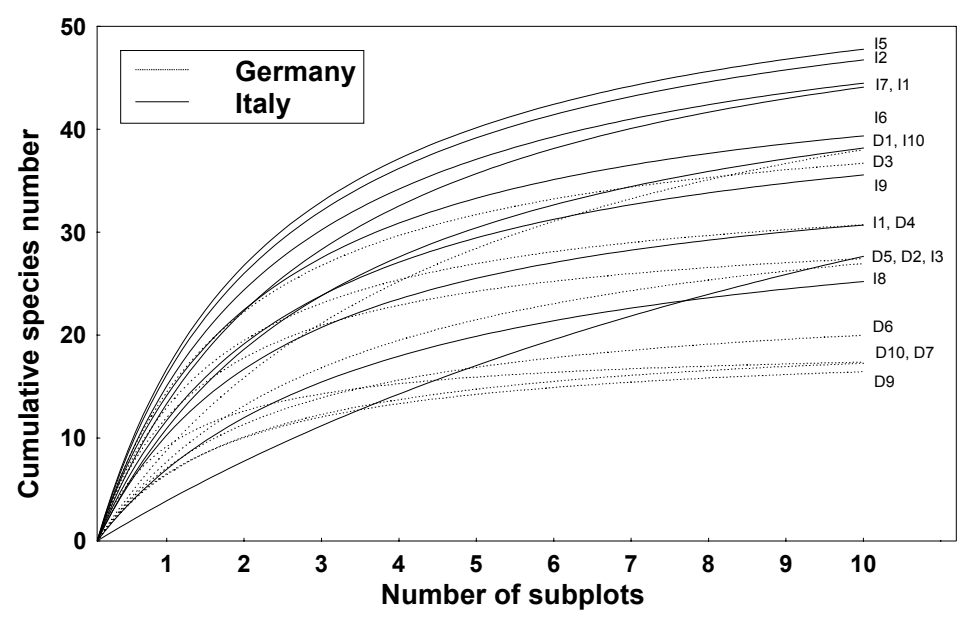

Fig. 5: Within-plot species accumulation curves for German and Italian plots, fitted to the Michaelis-Menten equation (see text).

Corresponding to previous results, dissimilarity between subplots was positively correlated with the estimated parameter $b$, which was derived from the species accumulation curve (Spearman's $\mathrm{r}_{\mathrm{s}}^{2}=0.581, \mathrm{p}<0.001, \mathrm{n}=19$ ). Similarly, $1 / b$ yielded a high positive correlation with similarity (Pearson's $\mathrm{r}^{2}=0.735, \mathrm{p}<0.001, \mathrm{n}=19$ ). The parameter $b$ was significantly higher in Italy (median 2.49) than in Germany (median $1.80, \mathrm{~F}_{1,18}=5.97, \mathrm{p}=0.030$ ).

Regional species richness, the estimated asymptotic value of the plot-based species accumulation curves for the two regions (Fig. 6, $\mathrm{r}^{2}=0.94,0.96$ ), accordingly revealed a significantly higher $\gamma$-diversity for the Italian plots of 422 species ( \pm 14.3 confidence interval) than for the German plots (197 \pm 8.9 species). Similar to the subplot accumulation curves, the 


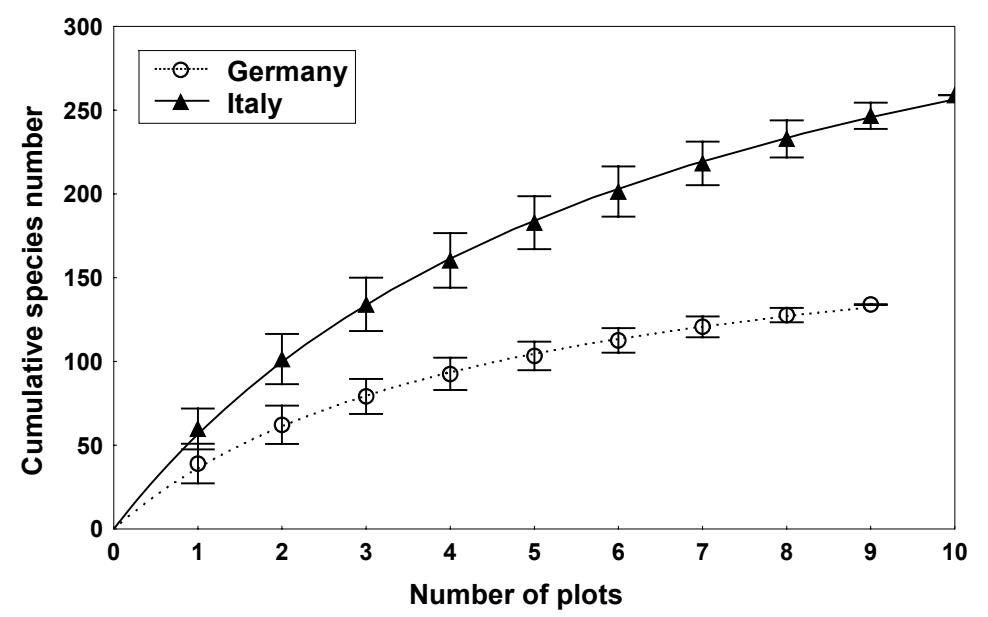

Fig. 6: Within-region species accumulation curves for Germany and Italy. Each point represent the mean of 1000 randomisations of plots fitted to the Michaelis-Menten equation. Error bars are standard deviations.

$b$ estimator ( $\beta$-diversity) was also significantly higher in Italy $(6.46 \pm 0.44)$ than in Germany $(4.42 \pm 0.45)$.

Averaging the estimates from the accumulation curves of both countries shows that species richness increased with scale level from a subplot richness of 11 species to an average plot richness of 50 species $(n=19)$, and finally to an average regional richness of 309 species $(n=$ 2). Differentiation diversity increased from subplot level with an average $b=3.1(\mathrm{n}=19)$ to an average $b=5.44$ on plot level $(\mathrm{n}=2)$.

\section{Relationships between different diversity levels}

Fig. 7 shows the relationship between different diversity levels. There was a significant positive correlation between species richness of subplots (internal $\alpha$-diversity) and plots $(\alpha$ diversity) (Fig. 7A). The slope of the linear regression without intercept for the pooled data was 0.24 . This means that about a quarter of all plant species in a plot are found within a random subplot of only $0.09 \mathrm{~m}^{2}$. However, this ratio of subplot species richness to plot species richness varied considerably, i.e. from 0.03 to 0.46 . There was no indication of a deviation from linearity since the linear model performed best, which implies proportional sampling conditions.

Dissimilarity between subplots (internal $\beta$-diversity) and species richness of subplots (internal $\alpha$-diversity) correlated negatively for the Italian plots only, implying that subplots in Italy were less dissimilar with increasing species number of the whole plot (Fig. 7B, Italy: $\mathrm{r}^{2}=$ $0.640, p=0.006, n=10$; Germany: $r^{2}=0.005, p=0.860, n=9$ ). 

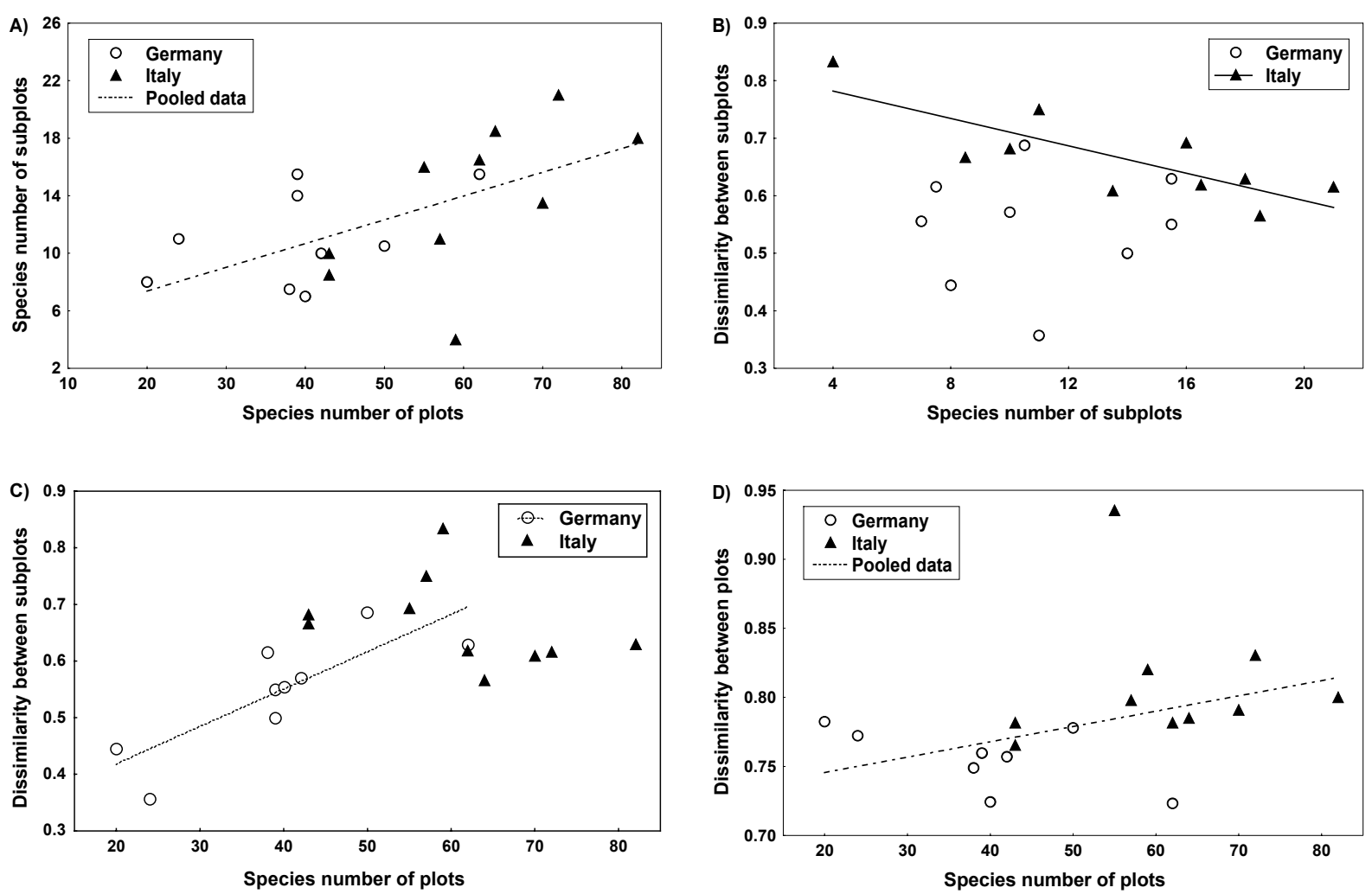

Fig. 7: Relationships between different diversity levels for German and Italian plots. A) Relationship between species richness of subplots (internal $\alpha$-diversity) and species richness of plots ( $\alpha$-diversity). B) Relationship between dissimilarity-between-subplots (internal $\beta$-diversity) and species richness of subplots (internal $\alpha$ diversity). C) Relationship between dissimilarity-between-subplots (internal $\beta$-diversity) and species richness of plots ( $\alpha$-diversity). D) Relationship between dissimilarity-between-plots ( $\beta$-diversity) and species richness of plots ( $\alpha$-diversity).

In contrast, species richness of plots ( $\alpha$-diversity) and dissimilarity between subplots (internal $\beta$-diversity) was correlated positively only for German plots. This implies that in Germany subplots were more dissimilar with increasing species number (Fig. 7C, Germany: $r^{2}=0.678$, $\mathrm{p}=0.006, \mathrm{n}=9 ;$ Italy: $\left.\mathrm{r}^{2}=0.298, \mathrm{p}=0.277, \mathrm{n}=10\right)$.

At the plot level, dissimilarity between plots ( $\beta$-diversity) increased with increasing species richness of plots ( $\alpha$-diversity) (Fig. 7D). However, this relationship was weak and was found for pooled data only (Spearman's $\mathrm{r}_{\mathrm{s}}^{2}=0.234, \mathrm{p}=0.007$ ). Nevertheless, it is an indication that plots are more dissimilar with increasing species number.

\section{Diversity and plot area}

Plot size varied in both countries over orders of magnitudes, between $4.3 \mathrm{~m}^{2}$ and $539 \mathrm{~m}^{2}$ in Germany and between $9.7 \mathrm{~m}^{2}$ and $989 \mathrm{~m}^{2}$ in Italy (Tab. 1).

There was no significant relationship between species richness of subplots (internal $\alpha$ diversity) and plot area. A significant relationship between species richness of plots ( $\alpha$ - 

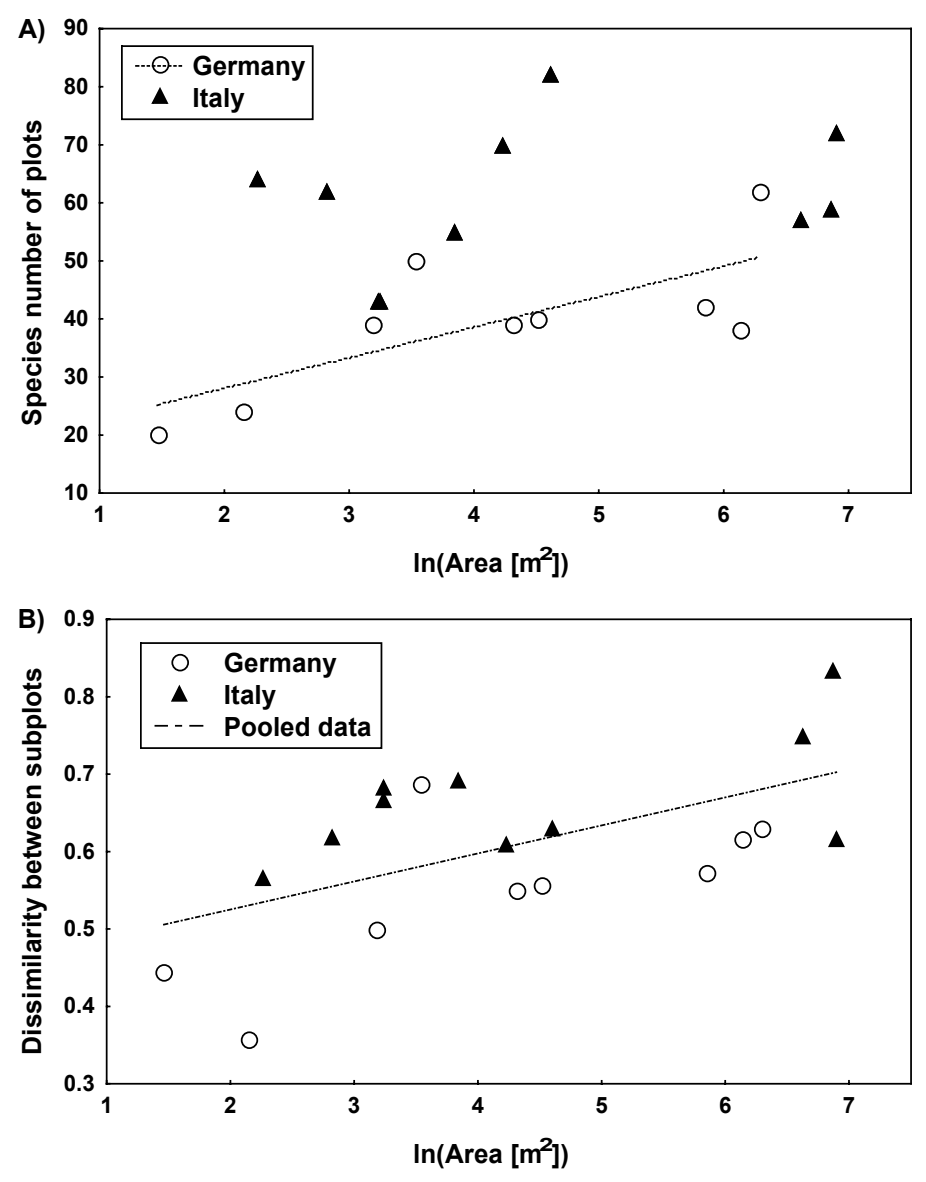

Fig. 8: A) Relationship between species richness of plots ( $\alpha$-diversity) and natural logarithm of plot area. B) Relationship between dissimilarity-between-subplots (internal $\beta$-diversity) and natural logarithm of plot area

diversity) and plot area was encountered for German plots only (Fig. 8 A). The best correlation was found with the natural logarithm of plot area $\left(r^{2}=0.733, p=0.025, n=9\right)$. Thus, large German plots tended to be richer in species than smaller ones.

Dissimilarity between subplots (internal $\beta$-diversity) increased with increasing logarithm of plot size (Fig. 8 B). This correlation was significant both for the German plots $\left(r^{2}=0.486, p=\right.$ $0.037, \mathrm{n}=9)$ and for the pooled data of both countries $\left(\mathrm{r}^{2}=0.331, \mathrm{p}=0.010, \mathrm{n}=19\right)$.

\section{Similarity decay}

The hypothesized relationship described by the semilogarithmic model (eq. 5) between similarity and distance between plots was confirmed for the German plots only (Fig. 9 A, $\mathrm{r}^{2}=$ $0.19, \mathrm{p}=0.008, \mathrm{n}=36$ ). The similarity decay rate (estimator $c$ in eq. 5 ) described a decline of the natural logarithm of similarity of 0.00535 per kilometre distance between plots.

In contrast, the similarity between Italian plots declined with increasing altitudinal difference of plots (Fig. $9 \mathrm{~B}, \mathrm{r}^{2}=0.532, \mathrm{p}<0.001, \mathrm{n}=45$ ). The decay rate $c$ was a decline of the natural logarithm of similarity of 0.000925 per meter altitudinal difference. The residuals from the regression on altitude were also significantly related to distance for the Italian plots, using the same non-linear model $\left(\mathrm{r}^{2}=0.114, \mathrm{p}=0.024, \mathrm{n}=45\right)$. Together, both topographical 

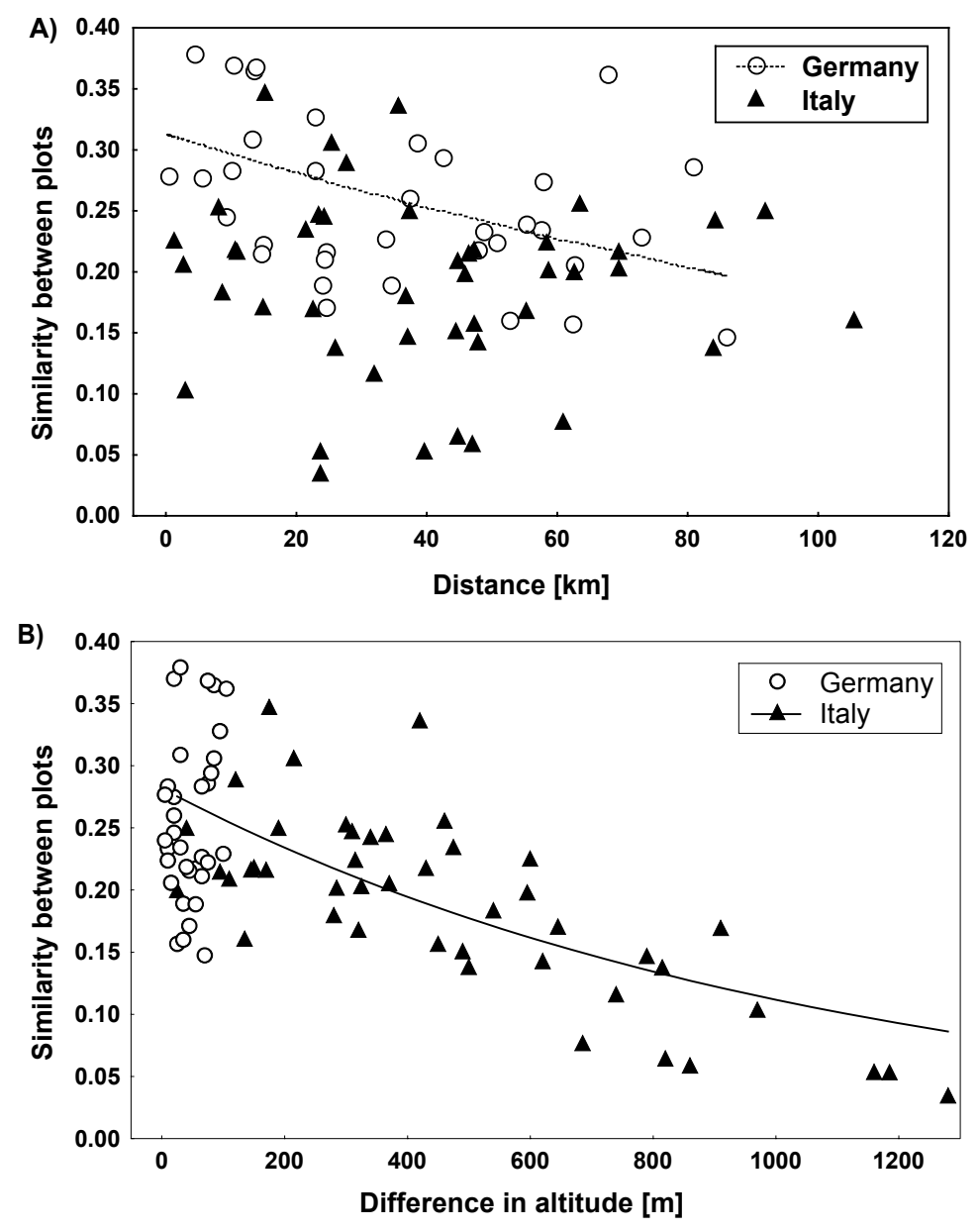

Fig. 9:A) Relationship between interplot similarity (1-dissimilarity) and inter-plot distance for Germany $(\mathrm{n}=36)$ and Italy $(\mathrm{n}=45)$. B) Relationship between inter-plot similarity and difference in altitude between plots for Germany $(\mathrm{n}=36)$ and Italy $(\mathrm{n}=45)$. The regression lines are based on eq. 5

parameters explain $64 \%$ of the variance in inter-plot similarity for the Italian plots. In contrast, such a multiple regression approach for the German plots did not enhance the explained variance.

\section{Discussion}

\section{Consequences of the study design}

In general, the highly standardised sampling scheme yielded results that corresponded very well to other, less systematic designs. In an intercontinental comparison of species-rich grassland communities, Sykes et al. (1994) found between 7.1 to 15 species on $0.01 \mathrm{~m}^{2}$ subplots and 20.4 to 33.4 species on $0.25 \mathrm{~m}^{2}$ subplots, compared to 4 to 21 species on $0.09 \mathrm{~m}^{2}$ in our study. Accumulated species richness of all subplots resulted in a maximum species richness of 39 species in Germany and 49 in Italy per $0.9 \mathrm{~m}^{2}$. For a similar vegetation type with $H$. petraea (dry calcareous alvar grassland on Öland) Bengtsson et al. (1988) reported a maximum of 51 species on $1 \mathrm{~m}^{2}$ (including cryptogamic species). The maximum species richness of Estonian alvar vegetation ranged between 32 (Pärtel et al. 2001), 40 (Zobel \& Liira 1997) and 45 vascular plant species on $1 \mathrm{~m}^{2}$ (Pärtel et al. 1996). 
The species richness found in our $H$. petraea plots was comparable to alvar grassland, as described by Pärtel et al. $\left(2001,53.1 \pm 2.8\right.$ species on $\left.15 \mathrm{~m}^{2}\right)$, except that we encountered a much higher variation (50.6 \pm 16.3 species). Pärtel et al. (2001) found 1.5 times more species in the plot richest in species than in the species-poorest plot, whereas this ratio was 4.1 between a German and an Italian plot, or 3.1 and 1.9 when the comparison was confined to German or Italian plots, respectively.

The higher variation might have different causes. First, this study covered a much larger area than comparable studies. Second, random sampling did not allow exclusion of subplots that obviously deviated in species number. Third, the varying plot size might have contributed to the higher variation.

This variable plot size can be considered a general disadvantage of the present design. Since in large plots distances between subplots were inevitably larger, spatial autocorrelation was lower than in smaller plots. This would explain the increasing internal $\beta$-diversity with plot size. Finally, this would result in a higher plot species richness. However, the variable plot size is exactly the tool that is needed to test these assumed relationships. The results for the Italian plots contradict the assumption of increasing $\alpha$-diversity with increasing plot size. The Italian plots approach saturation with species already at small plot sizes. We conclude that this is rather due to a limited species pool than to local species interactions because there was no indication of deviation from proportional sampling. Consequently, higher heterogeneity at increasing plot sizes was not of importance in Italian plots. In contrast, the German plots confirm the positive relationship between $\alpha$-diversity and plot size. Since they also followed the assumption of proportional sampling, the observed correlation is in this case probably explained by increasing heterogeneity at increasing plot sizes. Without a design with variable plot sizes these underlying mechanisms would not have emerged. Our hierarchical design has the further advantage that the diversity parameters are directly comparable between the subplot and plot levels.

\section{Appropriateness of species accumulation curves}

The estimators $a$ and $b$ of the Michaelis-Menten model were extremely closely related to species richness and dissimilarity, and thus, might provide reasonable descriptors of internal $\beta$-, $\alpha-, \beta$ - and $\gamma$-diversity. Although the correlations between the $a$ and $b$ estimators and observed species richness and dissimilarity were significant, there were considerable deviations from the Michaelis-Menten model in our study (data not shown). This might be due to the high variation in species richness mentioned above, but might also be caused by the 
fact that the Michaelis-Menten model is not independent of the underlying species distribution, as was shown by Keating \& Quinn (1998). Furthermore, Kikvidze (2000) showed that the performance of the Michaelis-Menten model depends on the proportion of rare species in the plots. The extrapolation error of the curve was positively correlated with the proportion of rare species, while the estimator $a$ was positively correlated with the number of common species.

Despite these reservations the Michaelis-Menten equation is the only model that allows a consistent evaluation of diversity indices by providing both estimators for inventory and differentiation diversity. In addition, the model is applicable across different scales.

\section{Comparison of diversity between Germany and Italy}

Although Italian plots exhibited a higher $\alpha$-diversity than German plots, internal $\alpha$-diversity was not different between the two study regions. This means that populations of Hornungia petraea in the species' distribution centre in Italy, although having more accompanying species than at the species' northern distribution limit in Germany, the single individual plant did not have more immediate neighbours of a different species. This is probably not an effect of interspecific competition because most plants in a subplot do not interfere with one another's leaves or roots because of their small plant size. More likely, the same internal $\alpha$ diversity indicates that the plot structure (e.g. stoniness of substrate) cannot not sustain a higher plant density in general, and thus, cannot support a higher species density. This interpretation is supported by the existence of plots with a very low vegetation cover due to a substrate rich in debris, such as I3 (Tab. 1), which simultaneously exhibit an exceptionally low species richness of subplots ( $7 \%$ of $\alpha$-diversity). A similar observation was made for the fauna associated with the coral Pocillopora damicornis (Black \& Prince 1983). When central, equatorial sites were compared to peripheral ones at higher latitude. There was no higher internal $\alpha$-diversity in coral populations closer to the equator than in ones from higher latitudes, although $\alpha$-diversity was higher in equatorial populations.

The most obvious explanation for the higher internal $\beta$-diversity in Italy would be that in Italy $H$. petraea occurs in more environmentally heterogeneous vegetation types compared to Germany. However, this is contradictory to our findings that $H$. petraea required relatively uniform site conditions. In particular for therophyte vegetation, internal $\beta$-diversity does not necessarily reflect environmental heterogeneity. This was shown by species mobility studies in the limestone grasslands of Öland (van der Maarel \& Sykes 1993). The authors showed that 
many species within a grid of $0.001 \mathrm{~m}^{2}$-cells showed a high degree of spatial fluctuation by appearing and disappearing in virtually all cells over a period of six years. The authors concluded that all species in the community had the same regeneration niche and that no species had preferences for particular microsites within the community. Similar high spatiotemporal dynamics have been found for various communities (e.g. Herben et al. 1990; Thórhallsdóttir 1990; Sykes et al. 1994; Herben et al. 1995), also including H. petraea populations (Geißelbrecht-Taferner et al. 1997). Alternatively, the higher internal $\beta$-diversity in Italy could be the consequence of its relationship to the level of $\alpha$-diversity (see below).

The fact that $\alpha$-diversity is higher in Italy than in Germany is a clear indication of a larger local species pool. Obviously, there are more calcareous grassland species present in Italy than are in Germany. Similar results were obtained by Qian et al. (1998) for stands of white spruce in North America. The $\alpha$-diversity was higher in the centre of this species' distribution range than in the periphery of its range.

The higher $\beta$-diversity between the Italian plots shows that $H$. petraea habitats are floristically more divergent in Italy than in Germany. This agrees with the observation that the altitudinal span of habitats was much larger in Italy than in Germany and that dissimilarity increased with altitudinal difference between plots in Italy. Another explanation would be that the higher $\beta$-diversity is the result of source-sink dynamics (Pulliam 2000) with the species having a larger reproductive output in the centre of its distribution range. Due to higher availability of propagules there would be more settlements in marginally favourable sites that represent sink habitats. However, our demographical studies on $H$. petraea contradict this hypothesis. They show that central populations had generally lower fecundity and lower densities (Kluth \& Bruelheide unpubl.).

Finally, the higher $\gamma$-diversity in Italy reflects higher species richness in the Mediterranean compared to Central Europe. Naturally, our study estimated $\gamma$-diversity only from nine and ten species lists and refers only to our focal community. The so-defined $\gamma$-diversity is only an estimation of the total species pool of potential coexisting plant species with $H$. petraea. However, it is amazing that the ratio our $\gamma$-diversity between the two regions corresponds so well with the total species richness of the two countries. Bases on our subplots, the ratio in species richness between Germany and Italy is $127 / 216=0.59$, based on all species recorded in our study the ratio is $187 / 313=0.60$, based on the regional floras the ratio is $1968 / 2800=$ 0.70 (Gubellini pers. communication; Korsch et al. 2002) and based on the national floras the ratio is $3320 / 5599=0.59$ (Oberdorfer 1983; Pignatti 1997). 
Relationships between different diversity levels

A positive correlation was detected between subplots' and plots' species richness. This could be expected under the assumption that there is no physical space limitation in subplots (Loreau 2000). The relationship is generally assumed to be linear over a wide range of plot species richness, but with a change from linearity to asymptotic saturation for large values of plot richness (Cornell \& Lawton 1992; Caley \& Schluter 1997). In the case of H. petraea plots, there was no evidence for a deviation from the linear model. This linearity implies that the local species pool in plots was sampled proportionally by the subplots. Furthermore, it is a hint that interspecific competition is generally not intense (Cornell \& Karlson 1997), something to be expected from therophyte communities with low cover values.

The linear model is in accordance with much field data. For example, Pärtel et al. (1996) found a strong positive linear correlation between local species richness and the species richness of $1 \mathrm{~m}^{2}$-subplots for 14 different Estonian plant communities. Similarly, species richness of $0.01 \mathrm{~m}^{2}$-subplots was correlated with species richness of $2.5 \mathrm{~m}^{2}$-plots in an intercontinental comparison of grassland types ranging from savannas to limestone grasslands (Sykes et al. 1994).

Since subplots are a subsample of plots we might assume that the local species pool controlled the internal $\alpha$-diversity in our specific therophyte vegetation type. Huston (1999) concluded from such a correlation of species richness between different hierarchical levels that the variation of processes on a lower level (subplot level) should have less importance than processes on a higher level (plot level). Indeed, low environmental variation on the subplot level would be in accordance with the small subplot variation in life cycle characteristics monitored on the same subplots (Kluth \& Bruelheide unpubl.).

The same arguments apply to the relationship between local and regional species richness. The higher regional species richness in Italy ( $\gamma$-diversity) controlled the $\alpha$-diversity of plots in H. petraea populations. Such a positive relationship between local and regional species richness has been documented in many cases (e.g. Ricklefs 1987; Pärtel et al. 1996b; Caley \& Schluter 1997; Lawton 1999). Following Huston's (1999) arguments, we could conclude that variation of plot level conditions are less important than those occurring between regions for H. petraea plots. Since plot selection was based on a species with narrow ecological amplitude, a comparatively low environmental variation between plots within a region could have been expected. However, it should be kept in mind that mechanisms cannot be inferred from patterns alone (Lawton 1999). Herben (2000) and Blackburn \& Gaston (2001) pointed 
out that the assumption of causality between regional and local species richness is in most cases unwarranted. In the case of $H$. petraea plots, the causality could also have the opposite direction, i.e. local species richness controlling regional richness.

Less equivocal relationships were obtained for differentiation diversity levels. Internal $\beta$ diversity and internal $\alpha$-diversity were negatively correlated in Italian plots only, a pattern that is expected with lottery recruitment, while internal $\beta$-diversity and $\alpha$-diversity were positively correlated in German plots only. Both relationships might just be the consequence of how $\alpha$-diversity is partitioned between its internal $\alpha$ - and $\beta$-components (Loreau 2000). Proceeding from the assumption made above that internal $\alpha$-diversity of subplots was close to maximum for the particular substrate of $H$. petraea plots, the possible number of species sampled in a subplot should be more or less constant. With a limited species number in one subplot, only a small portion of the large local species pool in Italian plots (i.e. the high $\alpha$ diversity) would be sampled by 10 subplots. Consequently, species composition would differ to a high degree between subplots, resulting in a high internal $\beta$-diversity. Under these conditions moderate variations in internal $\alpha$-diversity (due to moderate variations in stoniness, see above) would be reflected well in internal $\beta$-diversity. However, moderate variations in $\alpha-$ diversity would have less effect on internal $\beta$-diversity because the species pool is too large to be sampled close to completeness by using 10 subplots. Exactly this outcome was observed for Italian plots. This explanation is in accordance with studies in the extremely species-rich alvar vegetation in Estonia, where a negative relationship between $\beta$ - and $\alpha$-diversity was observed (Zobel \& Liira 1997; Pärtel et al. 2001).

In contrast, the small local species pool in German plots (i.e. the low $\alpha$-diversity) would be sampled to a much higher degree by 10 subplots if the number of species in a subplot were of the same magnitude as in Italy (i.e. similar internal $\alpha$-diversity in Germany and Italy, see above). In this case, species composition would differ only slightly between subplots, resulting in a low internal $\beta$-diversity. Under these conditions, moderate variations in internal $\alpha$-diversity would not be reflected well by internal $\beta$-diversity since sampling would be more or less close to completeness. In contrast, moderate variations in $\alpha$-diversity would have large effects on internal $\beta$-diversity. Precisely this was observed for the German plots. This interpretation would also be consistent with the observed dependence of $\alpha$-diversity on plot area in Germany. Since local species pools in Germany were comparably smaller and less saturated than in Italy, they were more prone to area effects than the species pools in Italy. 
The relationships to internal $\beta$-diversity are probably due to these methodological details of subsampling, whereas the correlations with $\beta$-diversity are probably not because the sampling at the plot level involved a complete species list. In contrast to the negative relationship between internal $\beta$-diversity and internal $\alpha$-diversity, a positive relationship was found for $\beta$ diversity and $\alpha$-diversity. Our explanation is that local species richness is composed of common and rare species. The ratio of common to rare species would be large in species-poor plots and low in species-rich plots. Consequently, species-rich plots have a high proportion of species confined to these particular plots. Finally, this would result in increasing $\beta$-diversity with increasing $\alpha$-diversity.

The role of rare and common species for diversity patterns was also studied by Pärtel et al. (2001). They found a positive relationship between the number of rare satellite species in a plot and the dissimilarity between $1 \mathrm{~m}^{2}$-subplots. Consequently, the degree of species rareness has a strong impact on the otherwise expected negative relationship between internal $\beta$ diversity and internal $\alpha$-diversity (Pärtel et al. 2001).

The main conclusion from the comparison of diversity levels is that the relationships between inventory diversity levels are clearer and offer more straightforward interpretations than those that involve differentiation diversity. Relationships with the latter depend on quality of the species pool (commonness or rarity), particularities of the study region and, in particular, on sampling methodology. Sample size of subplots determines whether to expect a negative relationship between internal $\beta$-diversity and internal $\alpha$-diversity or a positive relationship between internal $\beta$-diversity and $\alpha$-diversity. The clue is the degree of completeness of the subplot sampling procedure.

\section{Diversity and inter-plot distance (Similarity decay)}

The similarity decay observed for German plots was a decline in the natural logarithm of similarity of 0.00535 per kilometre distance between plots. We are not aware of any other studies of similarity decay in grassland or therophyte vegetation. The decay rate observed in our study is considerably larger than rates documented for forests. In black and white spruce forests in boreal North America, Qian et al. (1998) described decay rates between 0.00011 and 0.00037. In North American boreal and montane forests the natural logarithm of similarity declined between 0.00017 and 0.00067 per kilometre (Nekola \& White 1999). In tropical forests in Panama, Ecuador and Peru the decay rate ranged between 0.00055 and 0.00185 per kilometre (Condit et al. 2002). Similarly, the intercept value, which is a measure 
for similarity between adjacent plots, was much lower in our study (ca. 0.313) than in studies on forest ecosystems (0.60, Condit et al. 2002).

Since we chose a species with a narrow ecological amplitude for plot definition, exceptionally diverse ecological conditions of our study plots are probably not the reason for the steep similarity decline with inter-plot distance and the low intercept at least for the German plots. In contrast, we assume that the high similarity decay might be characteristic of therophyte vegetation in particular, but probably also for dry grassland and other xerophytic vegetation in general. In the European cultural landscape, these habitats show a highly fragmented distribution pattern, due to a scattered distribution of substrates. These vegetation types are characterized by a high proportion of endemic and rare species, of which many have a limited dispersal ability and low regeneration success. The profound change in land use in Europe has also further contributed to the isolation of these habitats. The result is a more unique species composition than in other types, which would explain the observed pattern in similarity decay.

\section{Acknowledgements}

We gratefully acknowledge the assistance of Leonardo Gubellini and Aldo Brilli-Cattarini from the Centro Ricerche Floristiche Marche for their help in locating appropriate plots in Italy, for organizing the field work, and, in particular, for plant identification. We express our thank to Ina Vetter, Ute Luginbühl, Stephanie Kluth, Holger Lieneweg, Christoph Fühner, Gustav Schulz and Ute Jandt for help in the field. Statistical support was provided by Edgar Brunner. Alexandra Erfmeier, Stephanie Kluth and two anonymous reviewers contributed valuable comments on the manuscript. We thank Daniel F. Whybrew for his help in the final linguistic polishing. This work was supported by a grant of the German Research Foundation DFG (BR 1698).

This chapter 2 of the present $\mathrm{PhD}$ thesis is republished by courtesy and permission of the "Journal of Biogeography” Blackwell Publishing, Oxford.

Nomenclature: Flora Europaea (Tutin 1968-1993) 



\title{
Central and peripheral Hornungia petraea populations: patterns and
} dynamics

\begin{abstract}
Evolutionary ecology assumes that, due to environmental and genetic stress, geographically peripheral populations tend to have low population densities. The presumably resulting pattern, the so called "abundant centre" distribution, has rarely been empirically investigated for plant species. In this paper we directly compare central populations of the annual Brassicaceae species Hornungia petraea in Italy with peripheral $H$. petraea populations in Germany. Ten central Italian and ten peripheral German populations were monitored for three vegetation periods. All life cycle stages, adult plant density, seed production, and pre- and post-dispersal seed bank density were studied in a nested sampling design in order to identify the specific demographic factors that explain the observed density patterns. In contrast to the "abundant centre" hypothesis, we found that German populations have higher densities than populations in the distribution centre, both in terms of adult plant and seed bank population densities. Fecundity was largely influenced by temporal effects, but only to a minor degree by the position within the range (i.e. country). High annual dynamics in fecundity were neither reflected in high annual dynamics of spring adult plant density nor in high annual seed bank dynamics. Significant differences were found in the seasonal seed bank dynamics between central and peripheral populations. Seasonal seed bank dynamics were more pronounced in peripheral German populations than in central Italian populations. We conclude that seasonal seed bank dynamics are a key factor in explaining differences in H. petraea density patterns, particularly in central populations, which incorporated fewer seeds into the seed bank than peripheral populations. Our results, based on an empirical study of all life cycle stages of $H$. petraea, do not conform to the "abundant centre" hypothesis. This is a further indication that a contrary pattern may be expected more frequently than generally assumed.
\end{abstract}

Keywords central-marginal model, "abundant centre" distribution, annual and seasonal seed bank dynamics, calcareous grasslands, nested repeated measures design

\section{Introduction}

A generally observed biogeographical pattern is the disintegration of more or less continuous distributions of species into exclaves towards the species' distribution limit (Walter \& Straka 1970; Brown \& Lomolino 1998). Associated with this landscape scale pattern is the 
assumption that peripheral or isolated populations of a species' distribution have reduced population sizes and densities (e.g. Hengeveld \& Haeck 1982; Brown 1984). In evolutionary ecology, two major components, environment and genetics, have been proposed to explain these patterns in the scope of the so-called central-marginal model (Brussard 1984; Siikamäki \& Lammi 1998).

The environmental component of the central-marginal model hypothesizes that reduced population sizes in geographically peripheral populations are the result of unfavourable environmental conditions experienced by individuals in those populations (Brussard 1984). Unfavourable growing conditions at a species' distribution limit are presumed to affect population densities directly via reduced fecundity or lower recruitment (e.g. Pigott \& Huntley 1981; García et al. 2000; Dorken \& Eckert 2001; Jump \& Woodward 2003) or indirectly as a result of a higher year-to-year variation in fecundity or recruitment resulting in higher annual population dynamics (Brussard 1984; Nantel \& Gagnon 1999). In general, comparisons of population dynamics at broad scales are rare for plant populations. To our knowledge, Nantel \& Gagnon (1999) is the only study of plant species that compares population dynamics of central and marginal populations. The authors studied two native clonal species, the perennial herb Helianthus divaricatus and the shrub Rhus aromatica. In both species, they found a larger interannual variation of vital rates and intrinsic growth rates in two populations at the northern limit of the species' distribution range (southern Quebec) than in two populations of each species from the central part of the distribution range (Ontario). Unfortunately, the authors provided no information as to whether these differences in growth rates of central and marginal populations are reflected in population densities as predicted by the central-marginal model.

The genetic component of the central-marginal model assumes that populations at a species' distribution limit have lower densities, which is associated with lower genetic variance compared to central populations (Wilson et al. 1991). The hypothesis of low marginal genetic variance has been intensively studied in the last several years. Both support (e.g. Lammi et al. 1999; Edenhamn et al. 2000; McCauley \& Ballard 2002; Tyler 2002) and rejection (e.g. Wilson et al. 1991; Safriel et al. 1994; Kaya \& Temerit 1994; Rehfeldt 1999; Metcalf et al. 2001) of the low-marginal-variance hypothesis have been reported, but population density has rarely been evaluated.

High demographic fluctuations may reduce the effective population size leading to population bottlenecks. These bottlenecks induce loss of genetic variance and reduce individual fitness 
(Hartl \& Clark 1997). Both the presumably higher extinction risk of peripheral populations and the potential adaptation of marginal populations to different environmental conditions turned the attention of conservation biology to marginal populations (e.g. Carson 1959; Haeck \& Hengeveld 1981; Safriel et al. 1994; Hoffmann \& Blows 1994; Lesica \& Allendorf 1995; Van Rossum et al. 1997; Van Rossum et al. 1999).

The negative genetic consequences expected from high demographic fluctuations could be buffered by seed banks, which may, in turn, conserve genetic variance (Baker 1989; McCue $\&$ Holtsford 1998) and affect effective population size (Nunney 2002). In a predictable environment (presumably at the distribution centre), all seeds should germinate in the next favourable season (Rees 1994) and unpredictability of the environment (presumably at the distribution's periphery) should favour allocation to the seed bank with a delayed germination at a time later than the next favourable season (Rees 1994). Whether banker or non-banker morphs are favoured by selection depends on life history traits other than the fraction of seeds allocated to the seed bank, e.g. on fecundity (Aikio et al. 2002). Although seed bank populations play an important role in population dynamics (in particular in annuals, where the long-term persistence of populations completely depends on seed banks; Baskin \& Baskin 2001; Aikio et al. 2002) and in evolutionary theory (e.g. Silvertown \& Lovett Doust 1993; Baskin \& Baskin 2001; Aikio et al. 2002), they have, to our knowledge, never been integrated in the central-marginal model.

Irrespective of the hypothesized processes in the central-marginal model, there is limited empirical evidence for the presumably resulting biogeographical pattern termed the "abundant centre" distribution, as shown in a recent review by Sagarin \& Gaines (2002b). There are very few plant species studies that directly compare central and peripheral population densities. Sagarin and Gaines (2002b) mention only two direct empirical studies on plant species (Vulpia ciliata ssp. ambigua, Carey et al. 1995, Lactuca serriola, Carter \& Prince 1985; Prince et al. 1985). Moreover, support (Carey et al. 1995) or rejection (Carter \& Prince 1985; Prince et al. 1985) of the "abundant centre" hypothesis in these studies was based on the authors' conclusions, but not on statistical tests (Sagarin and Gaines 2002b).

In addition to the position of a population within its geographical range, densities or life history traits of a population may vary, both within populations and between populations, in such a way that the population effects are superimposed on the range position ones. This fact needs to be taken into consideration in an adequate study design. 
In this paper, the "abundant centre" distribution is directly tested for the annual Brassicaceae species Hornungia petraea RCHB. (L.). Ten peripheral populations in Germany, where the species is considered rare and endangered, and ten central populations in Italy, where the species is common, are compared. We hypothesized that 1) Italian populations show higher densities than German populations for both adult plant and seed bank populations. As explanatory demographic factors we expect 2) fecundity of individuals to be lower in Germany, influenced both by environmental and genetic mechanisms and 3) dynamics of fecundity and population density to be more pronounced in peripheral German populations than in central Italian populations. 4) Annual seed bank dynamics should be less pronounced in peripheral German populations in order to buffer fluctuations in fecundity or adult plant population; whilst in the presumably more favourable and predictable central Italian populations the seasonal dynamics of seed bank population should be more pronounced. 5) Generally, we would expect the range position effect, i.e. the central-peripheral or "country" effect, to be more pronounced than the population effect.

A multi-factorial study design with nested factors repeated over three years was set up to partition density effects into effects of country, population and temporal effects. This study employs a statistical approach by combining two hierarchical levels and repeated measurements in one single statistical model.

\section{Methods}

\section{Study object}

Hornungia petraea RCHB. (L.) is a winter annual Brassicacea species of up to $15 \mathrm{~cm}$ height with the fruit generally bearing four seeds. It germinates in autumn and hibernates as a leaf rosette. Flowering occurs in early spring and seeds are released in early summer. The species has a persistent seed bank sensu Thompson \& Grime (1979), implying that at least few seeds in the soil date back to seed production older than one year.

H. petraea has a submediterranean-subatlantic distribution. Its distribution range is more or less continuous in the Mediterranean region and breaks down into smaller exclaves towards the distribution limit (Jalas \& Suominen 1996). At the distribution centre (Italy), the species occurs in more floristically divergent habitats than at the continental distribution limit in Germany (Kluth \& Bruelheide 2004c). H. petraea-habitats are open calcareous grasslands often dominated by therophytes. Sociologically, this therophyte vegetation belongs to the Alysso-Sedion (Oberdorfer 1978), which is a priority habitat type in the EU (Natura 2000 
Code 6110; European Council 1992). In addition, H. petraea is a rare species and is considered endangered in Germany (category 2, German Red Data Book, Korneck et al. 1996).

\section{Study sites}

The study was conducted in Italy and Germany. Italian study sites are representative of central populations of $H$. petraea; whereas populations in central Germany are allotted to the species' largest exclave at its continental north-eastern distribution limit. Transects of approximately $100 \mathrm{~km}$ in length were set up along the Apennine in central Italy (Marche and Umbria regions) and in Central Germany (Thuringia and Saxony-Anhalt). Each transect comprised ten plots. Each plot corresponded to an entire H. petraea population. In Germany, the complete west-eastern extension across the exclave was included, which resulted in a very steep climatic gradient although the altitude of German plots ranged only from 170 to $275 \mathrm{~m}$ a.s.l. Italian plots were selected with the aim of obtaining inter-plot distances comparable to the German plots. In Italy, the altitudinal gradient ranged from 280 to $1560 \mathrm{~m}$ a.s.1. More detailed information on our study plots is given in Kluth \& Bruelheide (2004c).

\section{Plot design and field sampling}

A major difficulty in sampling populations is the different shape and size of the area they cover. In order to be able to study differing populations in a comparable manner, we developed a special sampling design. We first arbitrarily defined the centre of each population. From this centre the distance towards the population boundary was measured in eight compass directions at $45^{\circ}$ intervals. Population boundaries were defined by the absence of $H$. petraea plants for a distance of at least 5 meters. The population boundaries were usually accompanied by a clear change in vegetation composition. The area covered by the population was calculated on the basis of the resulting octagon. A grid adapted to the specific area covered by the population was assigned by dividing the population area by 100 . Each grid cell within the octagon comprised $1 \%$ of the population surface area. Ten of these grid cells were randomly selected, and $30 \mathrm{~cm} * 30 \mathrm{~cm}$ subplots were established in the selected cells and marked permanently for sampling. In total, there were 100 subplots in Italy but only 90 in Germany because plot D8 of the German transect was destroyed several times by vandalism, resulting in only nine German plots. For further details on plot design see Kluth \& Bruelheide (2004c).

Field sampling was conducted from March 1999 to May 2001 over three successive vegetation periods of $H$. petraea. In total, each subplot was surveyed at 15 monitoring dates. 
In this paper only the spring census data (adult plants in their reproductive stage) were considered. This results in a total number of 570 field counts of density per subplot. If subplots contained $H$. petraea plants one individual was selected randomly and marked permanently. If subplot counts were zero the closest individual in the subplot's immediate surroundings was selected and marked. Fruits and residual dissepiments were counted. To obtain the seed number and thus, fecundity of individuals, the maximum counted number of fruits and dissepiments in each vegetation period was multiplied by 4 . Since population densities were very low in the spring of 2000 in the Italian populations I3, I9 and I10 $(n=9$, $\mathrm{n}=9, \mathrm{n}=6$, respectively), only a total of $\mathrm{N}=564$ records of fecundity data were collected.

Seed bank samples were taken before (spring) and after (summer) seed dispersal in 1999 and 2000. Seed bank samples were taken with an auger of $5.5 \mathrm{~cm}$ diameter and a height of $4 \mathrm{~cm}$ corresponding to a sampled surface area of $23.8 \mathrm{~cm}^{2}$. Each sample was taken randomly at eight predefined positions (corners, edges) adjacent to but outside the subplots. Thick snow cover at the Italian plot I4 resulted in a large delay in phenology and fruits had still not released seeds by the beginning of June. In this case, the June seed bank samples and counting data were considered as spring data. In consequence, there was no post-seed dispersal seed bank data for this population which resulted in a collected total of $\mathrm{N}=720$ seed bank samples.

\section{Seed bank analysis}

Seed bank samples were stored dry and dark at room temperature until the following autumn. They were then sieved and distributed into in plastic dishes on a bed of sterilised sand $(200 \mathrm{ml})$. The plastic dishes were arranged randomly in blocks in a greenhouse. Each block consisted of twenty positions of two randomly chosen samples of each population: one from the spring and one from the summer seed bank sample. The soil was kept permanently wet. The number of $H$. petraea plants was counted three times at four-week intervals. After an observation period of three months the 1999 seed bank samples were kept dry and dark for five months and were then watered again. Only very few $H$. petraea plants germinated in this second assessment. Thus, these additional data were disregarded and the 2000 seed bank samples were not watered a second time.

\section{Test statistics}

The data were analysed using a repeated measures analysis of variance for nested designs, in which the single counts of individuals and fecundity of individuals in subplots or germination events in seed bank samples were included. Census data were first tested for normal 
distribution (proc univariate, Shapiro-Wilk-statistics, SAS Institute 2000a). Since data were not normally distributed at $\alpha=0.05$, neither after log-transformation, we used non-parametric statistics based on rank transformation (proc rank, SAS Institute 2000a; for appropriateness of rank transformation see Brunner \& Puri 2001).

Using these data the analysis of variance was performed (proc glm, SAS Institute 2000b) with subplot as the temporal repeated subject for the class variables country and population, nested within country and referred to as Pop(Coun) in ANOVA tables. First, between-subjects effects were tested (in ANOVA tables referred to as "a"). Second, an univariate test for within-subjects effects assessed the repeated factor and its interactions with country and population (if necessary, the Greenhouse-Geisser adjustment was performed, section " $b$ " in our ANOVA tables). If the interactions of the repeated factor were significant, univariate tests of hypotheses for between-subjects effects for the repeated factor were performed separately (section $\mathrm{c}$ in ANOVA tables). In cases of multiple repetitions, i.e. more than twice, an analysis of variance was performed for each contrast between temporal repetitions. If either the population effect (in the between-subjects test) or the interaction effect of population with the repeated factor was significant, a post-hoc test (adjustment $=$ Tukey) for all single pairwise comparisons among the 19 plots was performed. Population dynamics were analysed by means of a contrasts analysis between years for each population. Significant contrasts between years indicate high population dynamics. In order to partition the explained variance between the different effects in the model, $R^{2}$ values are given in ANOVA tables both for the total model $\left(R_{\mathrm{t}}^{2}\right)$ and for the partial model $\left(R_{\mathrm{p}}{ }^{2}\right)$.

\section{Results}

\section{Adult plant population density}

Figure 1 shows spring population densities of all 19 studied populations for three successive years. Table 1 presents the results from the nested ANOVA with repeated measures of the rank transformed data presented in Fig. 1. The between-subjects effects explained $58 \%$ of the variance in the total model. Both, country and population had a significant influence on the density of adult $H$. petraea populations (Tab. 1a). The factor country explained $58 \%$ of the between-subjects variance in the partial model with higher densities in the peripheral German populations than in the central populations in Italy. The median density of German populations over the three successive years was 27 plants per subplot $(n=270)$ and only 1 individual per subplot $(n=300)$ in the Italian populations. The median values of the mean 

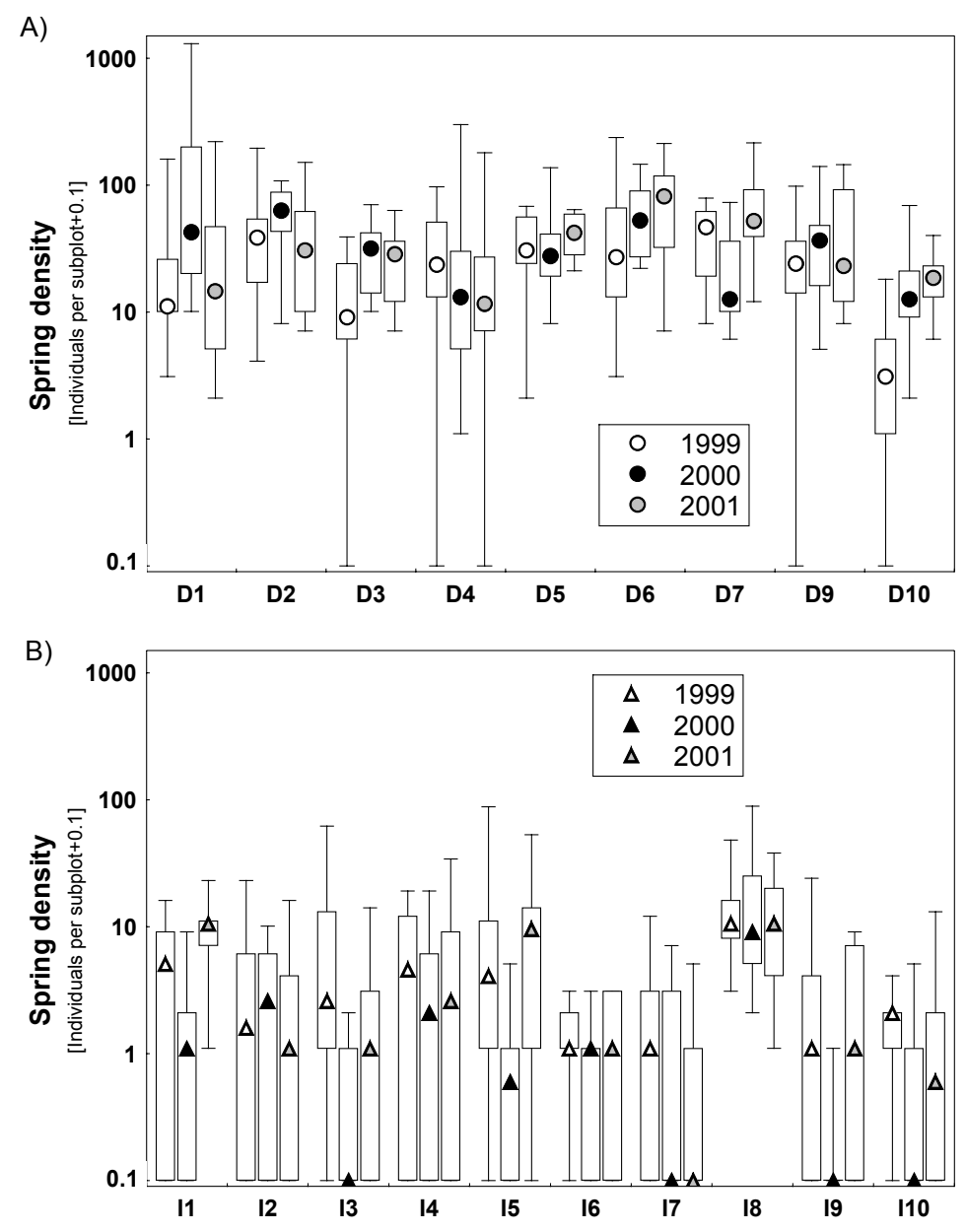

Fig. 1: Spring population density of adult Hornungia petraea plants in three successive years based on subplots of 30 $\mathrm{cm} * 30 \mathrm{~cm}$. A) peripheral German (D) and $\mathrm{B}$ ) central Italian (I) populations. Box-Whisker plots with median, 25 and $75 \%$-quantiles and extremes.

population densities of the two countries were 47 plants per $\mathrm{m}^{2}(\mathrm{n}=27)$ and only 3.4 plants per $\mathrm{m}^{2}(\mathrm{n}=30)$ for German and Italian populations, respectively. The factor population was less important, explaining $13 \%$ of the between-subjects variance. The univariate test for within-subjects effects revealed significant effects for all factors (Tab. 1b). This part of the model however explained only $6 \%$ of the variance of the total model. The factor year explained only $2 \%$ of the variance in the within-subjects model. The most important effect in the within-subjects section was the interaction of year and population explaining $22 \%$ of the variance (Tab. 1b). An additional $10 \%$ of the variance in the partial model was explained by the interaction of year and country (Tab. 1b) resulting from the fact that the contrast between the years 1999 and 2000 was not significant and that the contrast 2000/2001, with higher densities in 2001 than in 2000, was significant. For each of the contrasts the main effect of explained variance was between the populations and to a lesser degree between countries (Tab. 2). The univariate analysis for the repeated years yielded quite homogenous results with the main source of variance being the country and, to a lower degree, the populations (Tab. 1c). 
Tab. 1: Summary of nested repeated measures ANOVA of rank transformed spring population densities of adult Hornungia petraea plants (repeated subject $=$ subplot). a) Test of between-subjects effects. b) Univariate test of within-subjects effects. c) Univariate test of between-subjects effects separated by year. Coun $=$ Country i.e. central/peripheral, Pop $($ Coun $)=$ population nested within country. $R_{\mathrm{t}}^{2}$ : explained variation of total model. $R_{\mathrm{p}}{ }^{2}$ : explained variation of partial model.

\begin{tabular}{llrrrrrr}
\hline & Effect & df & SS & $F$ & $P$ & $R_{\mathrm{t}}{ }^{2}$ & $R_{\mathrm{p}}{ }^{2}$ \\
\hline a) & Coun & 1 & 7211557 & 337.1 & $<0.001$ & 0.47 & 0.58 \\
& Pop(Coun) & 17 & 1666210 & 4.6 & $<0.001$ & 0.11 & 0.13 \\
& Error & 171 & 3658555 & & & & \\
\hline b) & Year & 2 & 59812 & 5.6 & $<0.001$ & 0.00 & 0.02 \\
& Year*Coun & 2 & 265924 & 24.7 & $<0.001$ & 0.02 & 0.10 \\
& Year*Pop(Coun) & 34 & 598808 & 3.3 & $<0.001$ & 0.04 & 0.22 \\
& Error(Year) & 342 & 1843822 & & & & \\
\hline c) 1999 & Coun & 1 & 1383229 & 99.5 & $<0.001$ & & 0.31 \\
& Pop(Coun) & 17 & 749884 & 3.2 & $<0.001$ & & 0.17 \\
& Error & 171 & 2376888 & & & & \\
2000 & Coun & 1 & 3627289 & 472.4 & $<0.001$ & & 0.64 \\
& Pop(Coun) & 17 & 718576 & 5.5 & $<0.001$ & & 0.13 \\
& Error & 171 & 1313004 & & & & \\
2001 & Coun & 1 & 2466962 & 232.8 & $<0.001$ & & 0.49 \\
& Pop(Coun) & 17 & 796559 & 4.4 & $<0.001$ & & 0.16 \\
& Error & 171 & 1812485 & & & & \\
\hline
\end{tabular}

Tab. 2: Results of ANOVA for contrasts between the repeated spring density and fecundity of peripheral German (D) and central Italian (I) populations of Hornungia petraea. Direction of trends is indicated with algebraic signs for the mean and for the country effect when significant. Double signs indicate a steeper trend for the respective country.

\begin{tabular}{|c|c|c|c|c|c|c|c|c|}
\hline Stage & Contrast & Effect & $\mathrm{df}$ & $\mathrm{SS}$ & $F$ & $P$ & $R^{2}$ & Trend \\
\hline \multirow{8}{*}{ 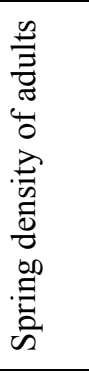 } & $1999 / 2000$ & Mean & 1 & 4628 & 0.37 & 0.545 & 0.00 & \multirow{3}{*}{$\mathrm{D}+, \mathrm{I}-$} \\
\hline & \multirow{7}{*}{$2000 / 2001$} & Coun & 1 & 530620 & 42.22 & $<0.001$ & 0.16 & \\
\hline & & Pop(Coun) & 17 & 621259 & 2.91 & $<0.001$ & 0.19 & \\
\hline & & Error & 171 & 2149017 & & & & \\
\hline & & Mean & 1 & 107384 & 13.23 & $<0.001$ & 0.05 & + \\
\hline & & Coun & 1 & 111481 & 13.73 & $<0.001$ & 0.05 & \multirow[t]{3}{*}{$\mathrm{I}+$} \\
\hline & & Pop(Coun) & 17 & 690949 & 5.01 & $<0.001$ & 0.30 & \\
\hline & & Error & 171 & 1388231 & & & & \\
\hline \multirow{8}{*}{ 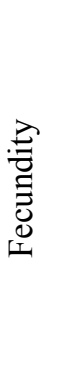 } & $1999 / 2000$ & Mean & 1 & 5199166 & 191.6 & $<0.001$ & 0.48 & - \\
\hline & \multirow{7}{*}{$2000 / 2001$} & Coun & 1 & 286581 & 10.6 & 0.001 & 0.03 & \multirow[t]{3}{*}{ D-, I-- } \\
\hline & & Pop(Coun) & 17 & 794004 & 1.7 & 0.043 & 0.07 & \\
\hline & & Error & 165 & 4476530 & & & & \\
\hline & & Mean & 1 & 1443538 & 45.9 & $<0.001$ & 0.17 & + \\
\hline & & Coun & 1 & 894532 & 28.5 & $<0.001$ & 0.10 & \multirow[t]{3}{*}{$\mathrm{D}+, \mathrm{I}++$} \\
\hline & & Pop(Coun) & 17 & 1183914 & 2.2 & 0.006 & 0.14 & \\
\hline & & Error & 165 & 5185858 & & & & \\
\hline
\end{tabular}

Note: since fecundity data of single subplots in the year 2000 was missing for contrast analyses a total $\mathrm{N}=184$ was used. 
Comparing all populations with one another for the three successive years, consistent significant differences between populations were mainly found between the populations of the two different study regions. Nearly fifty percent (47.8\%) of all pairwise comparisons between populations of the two different countries were consistently significant in all three years. In Germany, no consistent differences between populations were found over the three years; in Italy only $4.4 \%$ of the populations differed significantly and consistently. Plot I8 had significantly higher population densities than plots I6 and I7 in all three years.

\section{Population dynamics}

Table 3 shows the results of contrast analysis for the adult spring population densities. In Germany and in Italy, nine significant contrasts between years were detected. From 1999 to 2000 densities increased significantly in three and decreased significantly in one of the German populations. For the Italian populations, the direction of contrasts was more uniform with significant contrasts showing only negative trends. For all populations with significant contrasts in successive transitions the directions of the trends in 1999/2000 were the reverse of those observed in 2000/2001 (D1, D7, I5, I9, Tab. 3).

Tab. 3: Summary of contrasts between successive years of repeated measures ANOVA for spring population densities of adult Hornungia petraea plants and for fecundity. Separated analysis for the populations were performed. *: significant contrast $\mathrm{P}<0.05$, algebraic sign gives the direction of the trend.

\begin{tabular}{|c|c|c|c|c|}
\hline \multirow[t]{2}{*}{ Population } & \multicolumn{2}{|c|}{ Contrasts for spring adult plant density } & \multicolumn{2}{|c|}{ Contrasts for fecundity } \\
\hline & 1999:2000 & 2000:2001 & 1999:2000 & 2000:2001 \\
\hline D1 & $*+$ & *. & *_ & n.s. \\
\hline D2 & n.s. & $*_{-}$ & *_ & n.s. \\
\hline D3 & $*+$ & n.s. & *_ & $*+$ \\
\hline D4 & n.s. & n.s. & *_ & n.s. \\
\hline D5 & n.s. & n.s. & n.s. & n.s. \\
\hline D6 & n.s. & n.s. & n.s. & n.s. \\
\hline D7 & $*$ & $*+$ & n.s. & n.s. \\
\hline D9 & n.s. & n.s. & n.s. & n.s. \\
\hline D10 & $*+$ & n.s. & n.s. & $*+$ \\
\hline I1 & n.s. & n.s. & n.s. & $*+$ \\
\hline $\mathrm{I} 2$ & n.s. & n.s. & $*_{-}$ & n.s. \\
\hline I3 & $*_{-}$ & n.s. & n.s. & $*+$ \\
\hline I4 & n.s. & n.s. & n.s. & n.s. \\
\hline I5 & $*_{-}$ & $*+$ & n.s. & n.s. \\
\hline I6 & n.s. & n.s. & n.s. & $*+$ \\
\hline I7 & n.s. & n.s. & n.s. & $*+$ \\
\hline I8 & n.s. & n.s. & n.s. & $*+$ \\
\hline I9 & $*_{-}$ & $*+$ & n.s. & $*+$ \\
\hline $\mathrm{I} 10$ & $*_{-}$ & n.s. & n.s. & $*+$ \\
\hline
\end{tabular}




\section{Seed bank population}

Figure 2 shows the data of the seed bank population densities for the four repeated monitoring dates (spring 1999, summer 1999, spring 2000, summer 2000). Since the summer 1999 data for the Italian population I4 was missing, the complete data of population I4 was omitted in the nested repeated measures ANOVA (Tab. 4). The density of seed bank populations differed significantly between the two countries explaining $54 \%$ of the variance in the data set (Tab. 4a). This difference was observed on all four dates (Tab. 4c). In German seed bank samples, between 0 and 79 seeds germinated per sample of $23.8 \mathrm{~cm}^{2}$ (median $=5, \mathrm{n}=360$ ). In Italy, the maximum number of germinating seeds was only 26 (median $=0, n=360$ ). In addition to the country effect, the population effect explained $12 \%$ of the between-subjects effects (Tab. 4a).

The analysis of within-subjects effects (Tab. 4b) resulted in a significant portion of $17 \%$ of variance explained by the repeated factor (monitoring date). Therefore, the contrast analyses yielded significant general trends (Tab. 5). Except for the spring/summer 2000 contrast, trends showed, as expected, higher seed bank population densities in the summer seed bank than in the spring seed bank. The median spring seed bank population densities were 1786 and 274

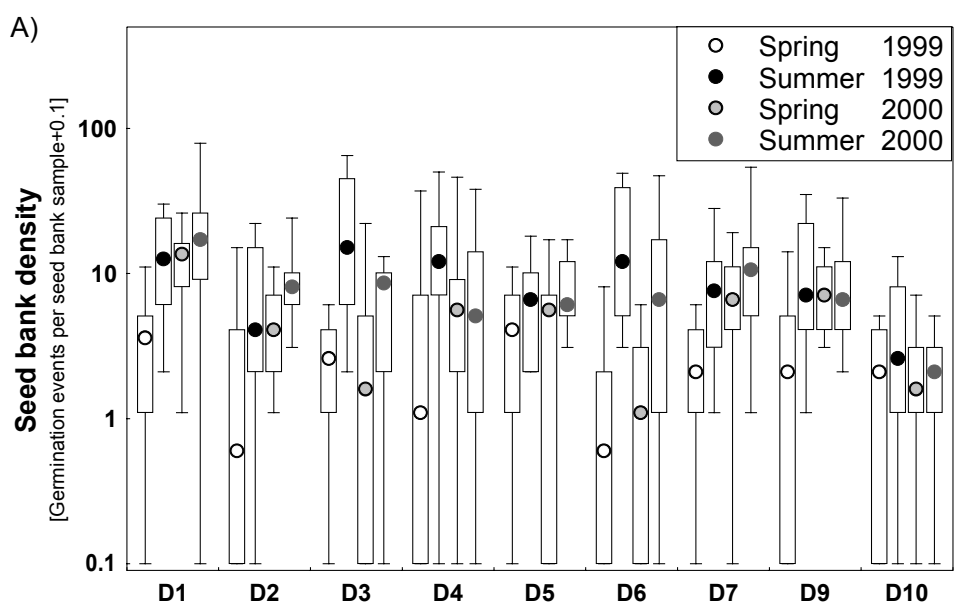

B)

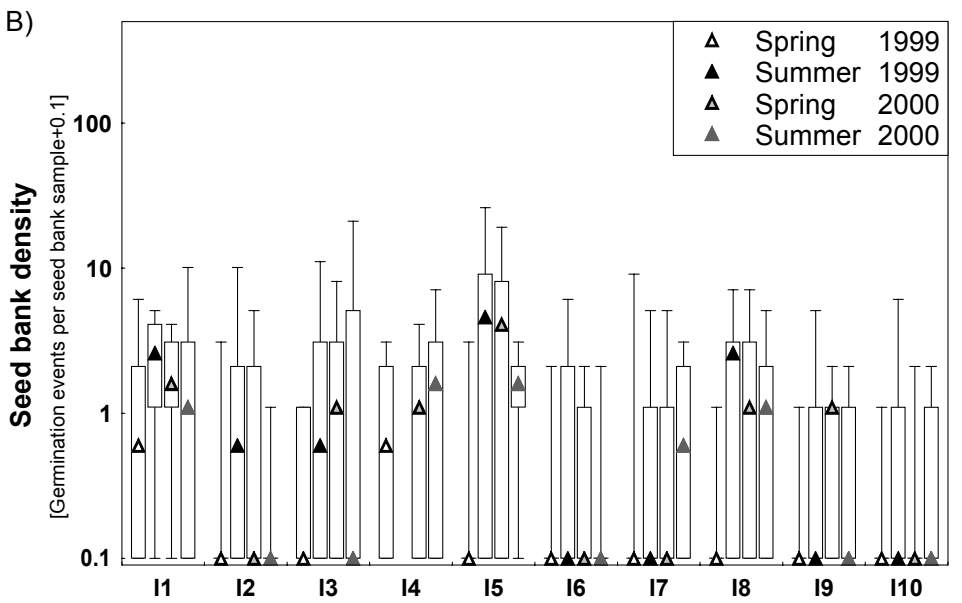

Fig. 2: Seed bank population density of Hornungia petraea on four repeated sample dates (spring 1999, summer 1999, spring 2000, summer 2000) based on sample surface of $23.8 \mathrm{~cm}^{2}$. A) Peripheral German (D) and B) central Italian (I) populations. Spring samples were taken before and summer samples after seed dispersal 
seeds $/ \mathrm{m}^{2}$ for Germany $(\mathrm{n}=18)$ and Italy $(\mathrm{n}=18)$, respectively. The summer seed bank densities were 4421 and 568 seeds $/ \mathrm{m}^{2}$ (median values) for German and Italian plots, respectively. The interaction of the repeated monitoring date and country was significant but explained only $2 \%$ of the variance of the partial model (Tab. $4 \mathrm{~b}$ ). The interaction of the repeated factor and population was not significant. In the first study year, 1999, differences in seed bank density between populations nested within country were not significant, but in the second study year populations explained a significant amount of the variance (Tab. 4c).

As expected, the contrast analysis yielded significant country effects (Tab. 5). Trends between two subsequent temporal repetitions were significantly different between the two countries. In general, the trends were less pronounced in Italy than in Germany. The contrasts between spring/summer 2000 had even different signs in the two countries. In German samples, more plants emerged from summer 2000 samples than from spring 2000 samples. For the Italian plots, an opposite trend was found.

Tab. 4: Summary of nested repeated measures ANOVA of rank transformed seed bank population densities of Hornungia petraea (repeated subject $=$ number of seedlings emerged from seed bank samples). a) Test of between-subjects effects. b) Univariate test of within-subjects effects. c) Univariate test of between-subjects effects separated by the monitoring date (spring 1999, 2000, summer 1999, 2000). Coun $=$ country i.e. central/peripheral, Pop(Coun) $=$ population nested within country. $R_{\mathrm{t}}^{2}$ : explained variation of total model. $R_{\mathrm{p}}{ }^{2}$ : explained variation of partial model.

\begin{tabular}{llrrrrcc}
\hline & Effect & df & SS & $F$ & $P$ & $R_{\mathrm{t}}{ }^{2}$ & $R_{\mathrm{p}}{ }^{2}$ \\
\hline a) & Coun & 1 & 8961035 & 263.5 & $<0.001$ & 0.30 & 0.54 \\
& Pop(Coun) & 16 & 1995604 & 3.7 & $<0.001$ & 0.07 & 0.12 \\
& Error & 162 & 5509747 & & & & \\
\hline b) & Date & 3 & 2153829 & 37.0 & $<0.001$ & 0.07 & 0.17 \\
& Date*Coun & 3 & 319178 & 5.5 & $<0.001$ & 0.01 & 0.02 \\
& Date*Pop(Coun) & 48 & 1125998 & 1.2 & 0.168 & 0.04 & 0.09 \\
& Error(Date) & 486 & 9427443 & & & & \\
\hline c) Spring 1999 & Coun & 1 & 1488124 & 72.9 & $<0.001$ & \\
& Pop(Coun) & 16 & 352652 & 1.1 & 0.379 & 0.27 \\
& Error & 162 & 3670899 & & & & \\
Summer 1999 & Coun & 1 & 2908938 & 112.0 & $<0.001$ & 0.35 \\
& Pop(Coun) & 16 & 701487 & 1.7 & 0.054 & 0.09 \\
& Error & 162 & 4611211 & & & & \\
Spring 2000 & Coun & 1 & 1481675 & 61.0 & $<0.001$ & & 0.21 \\
& Pop(Coun) & 16 & 1232198 & 3.2 & $<0.001$ & & 0.17 \\
& Error & 16 & 4343634 & & & & \\
Coummer 2000 & 1 & 3401475 & 158.0 & $<0.001$ & & 0.42 \\
& Pop(Coun) & 16 & 835264 & 2.4 & 0.003 & & 0.10 \\
& Error & 162 & 3829496 & & & & \\
\hline
\end{tabular}


Tab. 5: Results of ANOVA for contrasts between the repeated seed bank samples of peripheral (Germany, D) and central (Italy, I) populations of Hornungia petraea. P-values for contrasts and between-subjects effects are given. Direction of trends is indicated with algebraic signs for the mean and for the country effect if significant. Double signs indicate a steeper trend.

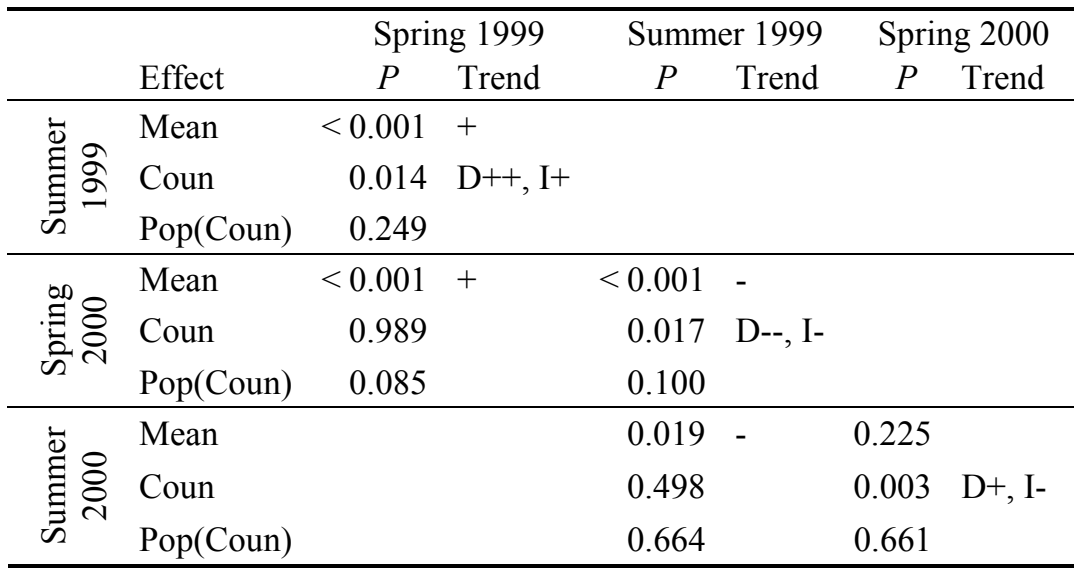

\section{Fecundity}

Figure 3 shows the data of fecundity of all populations of all three study years. The corresponding statistical results are summarized in Tab. 6. The total statistical model explained $41 \%$ of the variance. The between-subjects effects explained $13 \%$ of the total variance and the within subjects-effects $28 \%$. The between-subjects effects were mainly explained by population (34\%). A very small but significant amount of variance was explained by the fact whether the individual studied was from an Italian or German population. H. petraea plants from Germany had more seeds (median $=32$, mean $=78$, $\mathrm{n}=270$ ) than those from Italy (median $=30$, mean $=61, \mathrm{n}=294$ ). The repeated factor was significant explaining $29 \%$ of the within subject variance (Tab. 6b). The interactions between the repeated factor year and the subjects country and populations were also significant. This means that the number of seeds produced by an $H$. petraea plant depends on the year studied, the population from which it originates and whether it originates from a German or an Italian population (Tab. 6b). This result is confirmed by the univariate analysis of between-subject effects separated by the three study years. In the first year, 1999, there was no significant difference in fecundity between German and Italian $H$. petraea populations (median $=56, \mathrm{n}=$ 190), but in the following two study years the differences were significant (Tab. 6c). In 2000, German individuals had a higher fecundity (median $=20, n=90)$ than Italian ones (median = $12, \mathrm{n}=94$ ). In 2001, the fecundity of Italian individuals (median $=34, \mathrm{n}=100$ ) exceeded the fecundity of German individuals (median $=28, \mathrm{n}=90$ ). Consequently, the post-hoc test for the pairwise comparisons of populations yielded no consistently significant differences between populations over all three years. The differences in fecundity between two successive years 
for both contrasts $(1999 / 2000$ and $2000 / 2001)$ was significantly influenced by the factors population and country (Tab. 2).

In 2000 , the fecundity was generally lower than in the preceding year; whilst in 2001 it was higher than in 2000. In both years, the trends were more pronounced in the Italian plots than in the German ones (Tab. 2). The factor population significantly influenced both contrasts. This means that the trends were not equal in all populations (Tab. 2).
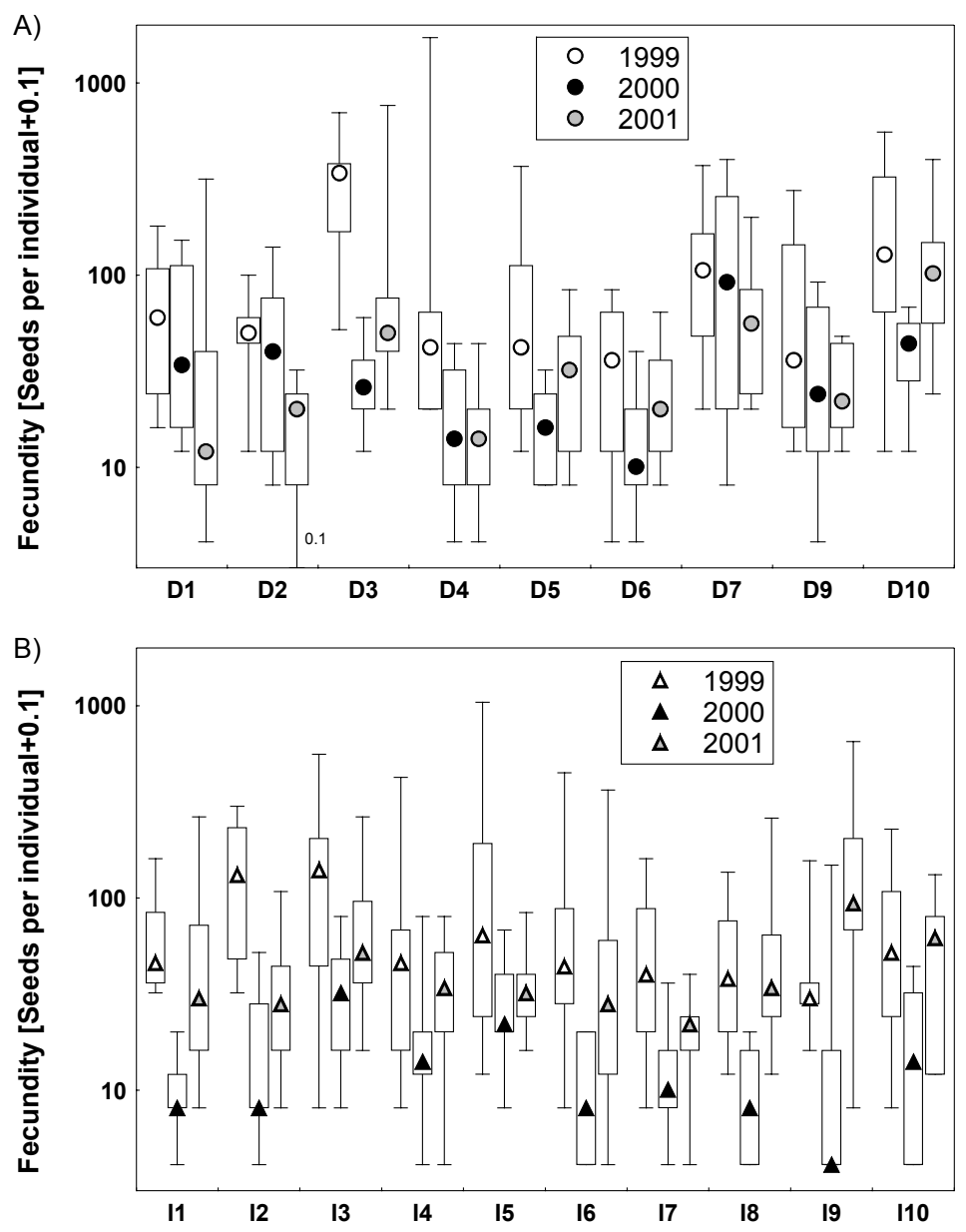

Fig. 3: Fecundity of Hornungia petraea individuals of three successive years. A) peripheral German (D) and B) central Italian (I) populations. Box-Whisker plots with median, 25 and $75 \%$ quantiles and extremes. 
Tab. 6: Summary of nested repeated measures ANOVA of rank transformed fecundity (seeds per individual) of Hornungia petraea $($ repeated subject $=$ subplot). a) Test of between-subjects effects. b) Univariate test of withinsubjects effects. c) Univariate test of between-subjects effects separated by year. Coun $=$ country i.e. central/peripheral, $\operatorname{Pop}($ Coun $)=$ population nested within country, $R e p=$ repeated factor. $R_{\mathrm{t}}^{2}$ : explained variation of total model. $R_{\mathrm{p}}{ }^{2}$ : explained variation of partial model.

\begin{tabular}{llrrcccc}
\hline & Effect & df & \multicolumn{1}{c}{ SS } & $F$ & $P$ & $R_{\mathrm{t}}{ }^{2}$ & $R_{\mathrm{p}}{ }^{2}$ \\
\hline a) & Coun & 1 & 88418 & 4.2 & 0.042 & 0.01 & 0.02 \\
& Pop(Coun) & 17 & 1812158 & 5.1 & $<0.001$ & 0.13 & 0.34 \\
& Error & 165 & 3461109 & & & & \\
\hline b) & Years & 2 & 2602096 & 85.1 & $<0.001$ & 0.18 & 0.29 \\
& Years*Coun & 2 & 449865 & 14.7 & $<0.001$ & 0.03 & 0.05 \\
& Years*Pop(Coun) & 34 & 935536 & 1.8 & 0.006 & 0.06 & 0.10 \\
& Error(Years) & 330 & 5046213 & & & & \\
\hline c) 1999 & Coun & 1 & 16913 & 0.89 & 0.346 & & 0.00 \\
& Pop(Coun) & 17 & 642643 & 2.0 & 0.014 & & 0.17 \\
& Error & 165 & 3121545 & & & & \\
2000 & Coun & 1 & 442739 & 28.3 & $<0.001$ & & 0.11 \\
& Pop(Coun) & 17 & 957512 & 3.6 & $<0.001$ & & 0.24 \\
& Error & 165 & 2585261 & & & & \\
2001 & Coun & 1 & 78630 & 4.6 & 0.033 & & 0.02 \\
& Pop(Coun) & 17 & 1147537 & 4.0 & $<0.001$ & & 0.28 \\
& Error & 165 & 2800514 & & & & \\
\hline
\end{tabular}

Note: since fecundity data of single subplots in the year 2000 was missing the complete data set for these subplots were omitted resulting in a total $\mathrm{N}=552$ for this analysis.

\section{Discussion}

In contrast to the "abundant centre" hypothesis, which assumes a distribution pattern with lower population densities at a species' distribution limit, we found central populations of $H$. petraea in Italy to have significantly lower densities than peripheral populations in Germany. This applied both to adult surface plant population and to seed bank population. Our results correspond to those of Sagarin and Gaines (2002b), who could find only little empirical evidence for an "abundant centre" biogeographical pattern. In their review the extent to which a contrary pattern has been found was not analysed. In their analysis of twelve intertidal invertebrates, higher densities for six species occurred at the distribution limit; whilst only two species were more abundant in the distribution centre (Sagarin \& Gaines 2002a). For plant species, empirical studies on the "abundant centre" distribution pattern are rare. In Lactuca serriola, there was no evidence for a decline in population density towards the species' northern distribution limit in Britain (Carter \& Prince 1985; Prince et al. 1985). On the contrary, Carey et al. (1995) found evidence for declining population densities towards the northern distribution limit of the annual species Vulpia ciliata ssp. ambigua in Britain. Recently, Jump \& Woodward (2003) confirmed the "abundant centre" hypothesis for the northerly distributed Cirsium heterophyllum; whereas Cirsium acaule, a species from 
southern parts of the UK, did not show the expected pattern. As higher densities at the distribution centre could not be shown for $H$. petraea and as densities were, on the contrary, higher at the distribution limit, our initial hypotheses regarding demography as an explanation of density patterns (hypotheses 2-5) need to be discussed on the grounds of these new conditions.

For the two species, V. ciliata and C. heterophyllum, that confirmed the "abundant centre" pattern (Carey et al. 1995; Jump \& Woodward 2003), a reduced fecundity at the species' distribution limit was found, which explained the lower densities. Reduced fecundity towards distribution limits is a frequently found pattern (e.g. Pigott \& Huntley 1981; Eckert \& Barrett 1993; García et al. 2000; Dorken \& Eckert 2001). In contrast, the small difference in fecundity between $H$. petraea individuals between the two study regions can scarcely explain the differences in density. Fecundity was affected to a high degree by the year of study, which even inverted the outcome of results. High interannual variation in seed production is especially well known in annuals (e.g. Mack \& Pyke 1983; Schmidt \& Levin 1985; Watkinson 1990). The higher fecundity dynamics in central Italian populations may have resulted in reduced density, but this was not reflected in increased year-to-year dynamics of adult spring population or seed bank population densities.

We hypothesized that annual seed bank dynamics should be more pronounced in the periphery, whilst seasonal seed bank dynamics should be more pronounced in the distribution centre. There was no evidence that annual seed bank dynamics were influenced by the position within the species' range (i.e. by country); whereas seasonal seed bank dynamics were significantly influenced by country. We found higher seasonal seed bank dynamics in Germany than in Italy. This corresponds to the observed density pattern and to the idea that lower seasonal seed bank dynamics must be expected under unpredictable conditions (Rees 1994). Especially the transition into the seed bank, i.e. the contrast spring/summer, showed clear differences between the two countries. In the second study year, Italian H. petraea populations even showed a significant negative trend in seed bank density. Thus, we conclude that Italian populations suffer from problems with seed incorporation into the seed bank. One explanation might be that seeds produced by individuals in Italian populations may have a lower germination rate. This was indeed found in greenhouse experiments for seeds collected from the Italian populations (Kluth \& Bruelheide, unpublished). However, many other factors, such as carry-over effects, predation, dispersal ability, interactions with the accompanying vegetation or simply storage conditions in the soil, may affect the post- 
dispersal seed fate or seed dormancy cycle (e.g. Van Tooren 1988; Ehrlén 2000; García et al. 2000; Cabin et al. 2000; Baskin \& Baskin 2001).

Higher emigration rates from local populations could be another reason for an increased seed loss in Italy. Additionally, a higher variation in the interannual reproduction rate (data not shown) may lead to a higher extinction risk of local populations in Italy. A higher extinction risk combined with higher colonisation rates increases interactions between the local populations, i.e. by metapopulation dynamics (Hanski \& Gilpin 1991). Indeed, we found some extremely small populations in the Italian study region, sometimes consisting of only one single individual, which may represent colonisation events. Therefore, the differences in local population densities in central and peripheral populations may be the result of different metapopulation structures.

Our hypothesis that temporal effects play a minor role compared to country effects in explaining the variance of density was confirmed for the spring adult population of $H$. petraea. The generally higher amount of temporal effects in seed bank population density was caused by the high seasonal dynamics of pre- and post-dispersal seed banks, which is typical for annuals. Seasonal dynamics therefore had a population-specific component since interactions between the repeated factor with population generally exceeded interactions of the repeated factor with the country factor. Some of the populations studied showed alternating patterns independent of the study region. This could be a result of a density dependent over-regulation of population density (Hassell 1975). Further aspects of density dependence in central and peripheral $H$. petraea populations will be discussed elsewhere. Fecundity of individuals was mainly explained by temporal and by population effects, both largely exceeding the country effect. This is typical for annual species, as has been discussed above.

However, the observed demographic pattern in central Italian H. petraea populations, - i.e. reduced seasonal dynamics of seed bank populations with an even negative incorporation rate of seeds into the seed bank, higher annual dynamics in fecundity, and a slightly reduced fecundity - might be the reason for the lower population densities. Ongoing analyses of the genetic structure of the study populations will further clarify whether Italian populations suffer from genetic stress or whether the between-population genetic variance is lower in Italy. This would support the assumption of higher metapopulation dynamics in central populations. Climatic environmental stress, directly reducing population performance, seems unlikely, since the comparison of germination and growth requirements from growth chamber 
experiments with actual field conditions, collected with automatic weather stations, showed that requirements were met better in central populations (Kluth \& Bruelheide, unpubl.).

The observed pattern for $H$. petraea might also be a result of one temporal sector during the dynamic process of range contraction (Holt 2003). Whatever genetic and environmental factors influence the observed population patterns, the contrary of the "abundant centre" pattern (so to speak an "abundant periphery" pattern) might be more frequent than generally expected.

\section{Acknowledgements}

We thank Christoph Fühner, Stephanie Kluth, Holger Lieneweg, Ute Luginbühl and Gustav Schulz for help in the field. Special thanks are due to Leonardo Gubellini and Aldo BrilliCattarini from the Centro Ricerche Floristiche Marche for their assistance in locating appropriate plots in Italy. Alexandra Erfmeier and Stephanie Kluth contributed valuable comments on the manuscript. This work was supported by a grant of the German Research Foundation DFG (BR 1698/2). 


\section{Transition rates between life cycle stages in natural populations of the annual plant Hornungia petraea: The combined effect of density-dependence, range position and inter-annual dynamics}

\section{Abstract}

Previous studies on density-dependence as a crucial factor regulating the growth of plant populations have mainly focused on the transition rates fecundity and survival. It is the objective of this study to investigate the density-dependence of all life stages of an annual plant species, Hornungia petraea, also including the germination rate and the rate of incorporation of seeds into the seed bank. The density-dependence of transition rates in the central and peripheral parts of the species' range were compared. According to the centralmarginal model, assumed unfavourable environmental conditions at the periphery should negatively affect transition rates, which are then expected to result in reduced population densities. Furthermore, a higher year-to-year variation in transition rates is expected at the periphery. As previous studies on Hornungia petraea had revealed an opposite pattern with lower population densities at the distribution centre in Italy than at the periphery in Germany, we focussed on differences in transition rates in order to reveal demographical reasons for the lower densities in the distribution centre. In particular, we hypothesised that the transition rates are lower, the inter-annual variation in transition rates is higher and the intensity of density-dependence is weaker at the distribution centre than at the periphery. For analysing the transition rates calculated from field data of ten peripheral and ten central populations over three years we used an autoregressive covariance strategy for repeated measures that included density effects and the effect of inter-annual variation. We found all three hypotheses to be confirmed, but the impact of range position, density-dependence and interannual variation differed among the transition steps. All transition rates but fecundity were higher in the German populations than in the Italian populations. The germination rate and the incorporation rate into the seed bank were strongly density-dependent. Central populations showed a larger inter-annual variation in fecundity and in winter survival rate. The only transition step with a stronger density-dependence in peripheral populations was the winter survival rate. In most cases, these differences between the distribution centre and the periphery would have not emerged without taking density-dependence of transition rates and inter-annual variation into account. The necessity and consequences of integrating densitydependence and inter-annual variation into the central-marginal model are discussed.

Keywords ANCOVA, biogeography, demography, scale, spatio-temporal variation 


\section{Introduction}

Among all those factors that regulate population growth of plants, the density of individuals is the crucial one. Density acts by increasing competition intensity (Kira et al. 1953; Yoda et al. 1963; Harper 1977), by decreasing pollination events (e.g. Reusch 2003; Knight 2003), by increasing the attraction to predators (Cabin et al. 2000) or by increasing the risk of infection by pathogens or herbivores (Antonovics \& Levin 1980). Considering the entire life cycle of a species, either single transition steps or all the stages of the life cycle may be regulated by the density of the population in the previous time step (see Palmblad 1968). In the case of, for example, an annual plant species' life cycle, the transition probability from seed in the seed bank to seedling or juvenile plant (germination rate) may well depend on the initial seed density. The transition rates from the juvenile to the reproductive adult plant (survival rate), from the adult plant to the seed (fecundity) and from the seeds produced to the seeds in the seed bank (incorporation rate) might depend on the corresponding density in the population.

In plant population biology, there is a vast number of examples of density-dependence, in particular for the transition fecundity and for the survival rate from seedlings to reproductive plants, by manipulating the density of natural or artificial populations (see examples in Harper 1977; Begon et al. 1996; Silvertown \& Charlesworth 2001; Vandermeer \& Goldberg 2003). Generally, a negative relationship between transition rates and density was found if a threshold density is exceeded and intraspecific competition reduces the available resources for the individual, with the result of a decreasing per capita seed yield and a decreasing survival rate. The density-dependence of transition rates other than the fecundity and the survival rate of plants have been considered to a lesser extent (Antonovics \& Levin 1980), although in some cases evidence for density-dependent germination rate and incorporation rate were found. Patterns of density-dependence of germination and incorporation rates, however, are less consistent than those of fecundity and survival. Both positive and negative effects of seed density on germination have been reported; whereas in other cases germination rates proved to be independent of seed density (Ballard 1958; Palmblad 1968; Murray 1998; Lortie \& Turkington 2002; Orth et al. 2003). Information on the density-dependent incorporation rate of seeds into the seed bank, including all post dispersal seed movements, is also very scarce. In the desert mustard Lesquerella fendleri, Cabin et al. (2000) found a higher rate of seed loss due to predation by rodents at higher seed densities than at lower seed densities.

In evolutionary ecology, small and isolated populations are generally expected at species distribution boundaries (Hengeveld \& Haeck 1982; Brussard 1984; Brown 1984). In the so 
called central-marginal model peripheral populations are expected to be exposed to unfavourable environmental conditions (Brussard 1984) that have the effect of reducing population density or population size via reduced transition rates, e.g. fecundity or lower recruitment (Pigott \& Huntley 1981; García et al. 2000; Dorken \& Eckert 2001; Jump \& Woodward 2003).

This expected range position effect on transition rates may be obscured by density that equally effects the transition rates. For example, differences in transitions between central and peripheral populations may be sufficiently explained by density, but not by the range position effect. Therefore, density-dependence of transition rates should be incorporated into the central-marginal model, but it has been nearly completely neglected in practice, although Brussard (1984) did point out the importance of the integration of demography into the central-marginal model.

A higher year-to-year variation in environmental conditions may also be considered to be unfavourable conditions (Brussard 1984). This would then result in higher inter-annual population fluxes at the periphery of a species distribution (Brown 1984; Gaston 1990; Brown et al. 1995). Although it is expected that variability in population densities changes over a species range (Lundberg et al. 2000), temporal variability in population density across a species range has rarely been studied (Williams et al. 2003). Williams et al. (2003) analysed population dynamics across geographical ranges of three small game species in North America. In all three species, peripheral populations with lower mean abundance tended to exhibit greater temporal population variability. Nantel \& Gagnon (1999) studied two native clonal species, the perennial herb Helianthus divaricatus and the shrub Rhus aromatica. They found a larger inter-annual variation of vital rates and intrinsic growth rates in two populations of each species at the northern limit of the species' distribution range (southern Quebec) than in two populations of each species from the central part of the distribution range (Ontario). This is, to our knowledge, the only study of plant species that compares the population dynamics of central and peripheral populations. As discussed above for the case of population densities, the inter-annual variation in population density could also obscure the range position effect on transition rates and therefore should also be considered in the centralmarginal model.

However, the assumed biogeographical pattern of low population densities at a species' distribution limit and high population densities at its distribution centre, has rarely been corroborated (Sagarin \& Gaines 2002bb). Indeed, contrary patterns have also been described 
recently. In their analyses of twelve intertidal invertebrates Sagarin \& Gaines (2000a) found higher densities for six species at their distribution limits; whilst only two species were more abundant at their distribution centre.

The study object of this paper, Hornungia petraea, does also not meet the expectations of higher population densities at its distribution centre. Kluth \& Bruelheide (2004a) found that central Italian populations of $H$. petraea had lower population densities than peripheral populations in Germany. At the level of subplots of $30 \mathrm{~cm} * 30 \mathrm{~cm}$, the range position explained most $(47 \%)$ of the variance in population density; whilst only a small fraction $(6 \%)$ of the variance was explained by inter-annual differences. The authors concluded that seasonal seed bank dynamics are a key factor in explaining lower population densities in central populations in Italy, since contrasts between repeated spring and summer seed bank samples yielded significant differences in the trends of central and peripheral $H$. petraea populations.

The objective of this paper is to include density-dependence of transition rates and their interannual variation in the central-marginal model for the annual plant $H$. petraea. Ten natural populations were monitored at the species' distribution centre in Italy and ten at the distribution periphery in Germany over three successive vegetation periods. Transition rates and densities were calculated from H. petraea count data (Kluth \& Bruelheide 2004a). We analysed all transitions in the life cycle using an autoregressive covariance strategy for repeated measures in order to compare a series of regression models (Littell et al. 1996). The analysis of covariance strategy used, offers the advantage of distinguishing the impact of density-dependence, range position and temporal repetition (dynamic component) on transition rates. This model was used in order to explain the counter intuitive pattern of $H$. petraea, which exhibited lower population densities at the species distribution centre.

In particular we hypothesize 1) that central and peripheral populations differ in transition between life cycle stages when taking the effects of density and year-to-year variation into account. We expect that transition rates are lower at a given density in Italy, the region with lower population densities, than in Germany. We hypothesize that, 2) central and peripheral populations differ in inter-annual variation of transition rates when controlling for the effect of density. We expect a higher year-to-year variation of transition rates in central Italian populations than in peripheral German populations. Finally, we hypothesize that 3) central and peripheral populations differ in the magnitude of their density-dependence. We expect density-dependence of transition rates in Italy with lower population densities to be weaker than in Germany. 


\section{Methods}

\section{Study object}

The studied plant species, Hornungia petraea RCHB. (L.) (Brassicaceae), has a typical life cycle of winter annual species (Fig. 1). Reproductive adult plants can be found in early spring. The plants grow up to a height of $15 \mathrm{~cm}$, and their fruits generally have four seeds, which are released in early summer when the plants die off. Seeds germinate from the seed bank in autumn. The juvenile vegetative plants hibernate as a leaf rosette that then again reaches the reproductive stage in spring. The species has a persistent seed bank (Kluth \& Bruelheide 2004a); which means that the seeds in the seed bank are viable for more than one year (Thompson \& Grime 1979).

The distribution range of $H$. petraea is submediterranean-subatlantic with a continuous distribution in the Mediterranean region and smaller exclaves towards the distribution limit (Jalas \& Suominen 1996). At the Italian distribution centre, the species occurs in habitats that are floristically more divergent than at the continental distribution limit in Germany (Kluth \& Bruelheide 2004c).

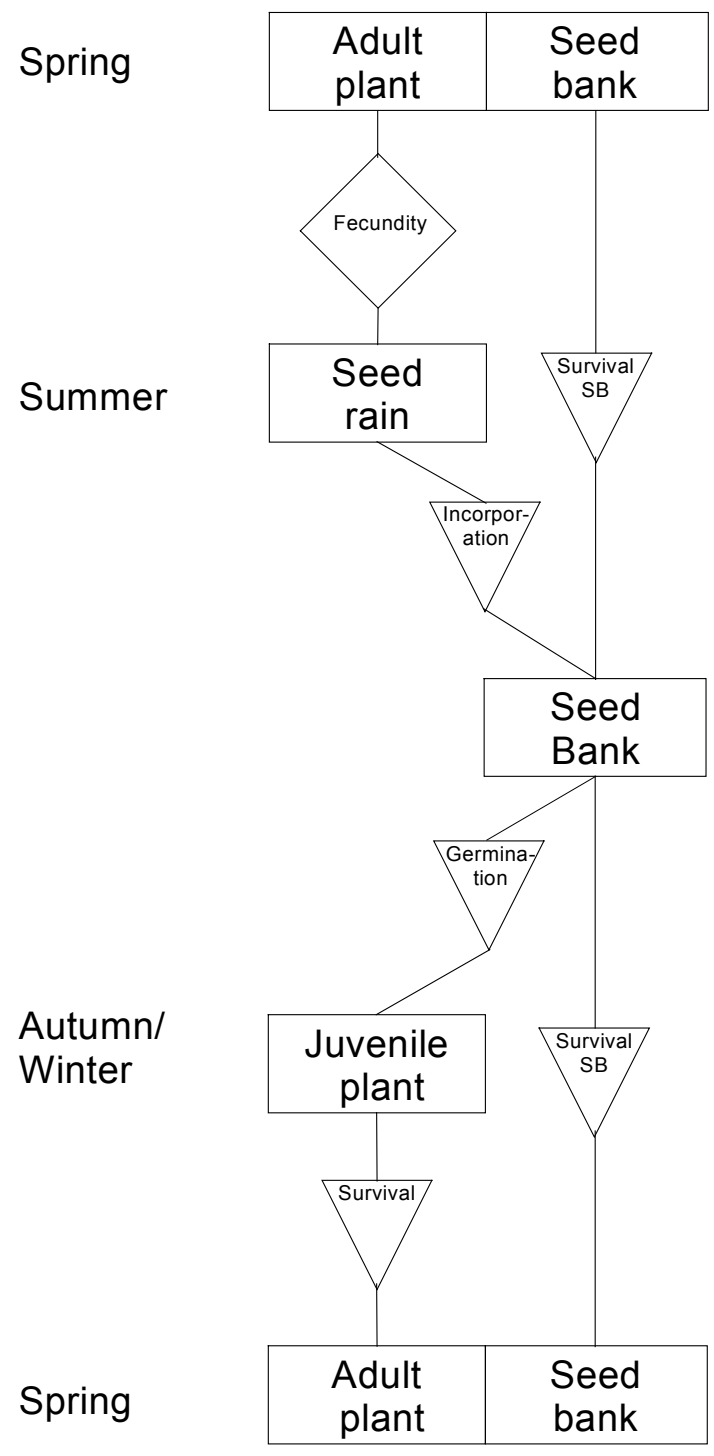

Fig. 1: Schematic life table of Hornungia petraea. Studied stages in the life cycle are shown as quadrangles, calculated transition probabilities as triangles and the transition fecundity as diamond. $\mathrm{SB}=$ Seed bank.

\section{Study plots}

The study was conducted at the species' distribution centre in Italy and at its continental north-eastern distribution limit in Germany, where the species' largest exclave can be found. Ten plots were selected on transects with a length of $100 \mathrm{~km}$ along the Apennine in central Italy (Marche and Umbria regions) and in central Germany (Thuringia and Saxony-Anhalt). Each plot comprised an entire $H$. petraea population. More detailed information on our study plots is given in Kluth \& Bruelheide (2004c). 
Plot design and field sampling

In each population ten $30 \mathrm{~cm} * 30 \mathrm{~cm}$ subplots were randomly selected and permanently marked for monitoring purposes. In total, 100 subplots were established in each country. As plot D8 of the German transect was destroyed several times by vandals, only 9 plots (90 subplots) remained for data analysis.

Subplots were sampled from March 1999 to May 2001 over three successive H. petraea vegetation periods. In total, each subplot was censused on 15 monitoring dates. Nine of these 15 dates were used to calculate the rates of the main transition steps between life cycle stages (Tab. 1). One individual H. petraea plant was selected randomly per subplot, permanently marked, and its fruits and the remaining dissepiments were counted.

Seed bank samples were taken in close proximity to each subplot before and after seed dispersal (spring and summer 1999 and 2000, respectively). Seed bank samples were taken with an auger of $5.5 \mathrm{~cm}$ in diameter and $4 \mathrm{~cm}$ height, this corresponds to a surface area of $23.8 \mathrm{~cm}^{2}$. Prolonged snow cover at the Italian plot I4 resulted in a strong delay in phenology. The plants had no ripe fruits by the beginning of June. In this case, the June seed bank samples and counting data were considered as spring census data (Tab. 1). Therefore, no post

Tab. 1: Field sampling dates of peripheral (Germany, D) and central (Italy, I) populations of Hornungia petraea. Stages studied are AP: adult plants, SB: seed bank, F: fecundity, JP: juvenile plants.

\begin{tabular}{llllllllll}
\hline Season & Spring & Spring & Summer & Autumn & Spring & Summer & Autumn & Spring & Spring \\
Year & 1999 & 1999 & 1999 & 1999 & 2000 & 2000 & 2000 & 2001 & 2001 \\
Stage & AP, SB, F & F & SB & JP & AP, SB, F & F, SB & JP & AP, F & F \\
Plot & & & & & & & & & \\
\hline D1 & $08 / 04$ & $13 / 05$ & $23 / 06$ & $01 / 11$ & $06 / 04$ & $23 / 05$ & $13 / 11$ & $19 / 02$ & $30 / 05$ \\
D2 & $08 / 04$ & $04 / 05$ & $30 / 06$ & $01 / 11$ & $04 / 04$ & $23 / 05$ & $13 / 11$ & $19 / 02$ & $30 / 05$ \\
D3 & $10 / 04$ & $04 / 05$ & $23 / 06$ & $01 / 11$ & $04 / 04$ & $23 / 05$ & $13 / 11$ & $19 / 02$ & $30 / 05$ \\
D4 & $08 / 04$ & $06 / 05$ & $23 / 06$ & $01 / 11$ & $04 / 04$ & $23 / 05$ & $13 / 11$ & $19 / 02$ & $30 / 05$ \\
D5 & $10 / 04$ & $06 / 05$ & $21 / 06$ & $03 / 11$ & $06 / 04$ & $23 / 05$ & $14 / 11$ & $19 / 02$ & $30 / 05$ \\
D6 & $10 / 04$ & $06 / 05$ & $21 / 06$ & $03 / 11$ & $06 / 04$ & $23 / 05$ & $14 / 11$ & $19 / 02$ & $31 / 05$ \\
D7 & $09 / 04$ & $05 / 05$ & $22 / 06$ & $02 / 11$ & $05 / 04$ & $23 / 05$ & $14 / 11$ & $20 / 02$ & $31 / 05$ \\
D9 & $09 / 04$ & $05 / 05$ & $22 / 06$ & $02 / 11$ & $05 / 04$ & $23 / 05$ & $14 / 11$ & $20 / 02$ & $31 / 05$ \\
D10 & $09 / 04$ & $05 / 05$ & $22 / 06$ & $02 / 11$ & $05 / 04$ & $23 / 05$ & $14 / 11$ & $20 / 02$ & $31 / 05$ \\
I1 & $03 / 04$ & $19 / 05$ & $12 / 06$ & $07 / 11$ & $02 / 04$ & $27 / 04$ & $24 / 11$ & $25 / 02$ & $09 / 05$ \\
I2 & $08 / 04$ & $20 / 05$ & $10 / 06$ & $07 / 11$ & $02 / 04$ & $27 / 04$ & $25 / 11$ & $04 / 03$ & $10 / 05$ \\
I3 & $11 / 04$ & $25 / 05$ & $10 / 06$ & $08 / 11$ & $03 / 04$ & $26 / 04$ & $26 / 11$ & $04 / 03$ & $10 / 05$ \\
I4 & $09 / 06$ & & & $09 / 11$ & $26 / 04$ & $12 / 06$ & & $20 / 05$ & \\
I5 & $21 / 04$ & $24 / 05$ & $08 / 06$ & $09 / 11$ & $03 / 04$ & $11 / 06$ & $27 / 11$ & $05 / 03$ & $20 / 05$ \\
I6 & $18 / 04$ & $22 / 05$ & $08 / 06$ & $08 / 11$ & $03 / 04$ & $26 / 04$ & $26 / 11$ & $04 / 03$ & $10 / 05$ \\
I7 & $04 / 04$ & $27 / 05$ & $27 / 05$ & $09 / 11$ & $05 / 04$ & $25 / 04$ & $29 / 11$ & $01 / 03$ & $11 / 05$ \\
I8 & $14 / 04$ & $28 / 05$ & $28 / 05$ & $10 / 11$ & $05 / 04$ & $25 / 04$ & $30 / 11$ & $03 / 03$ & $11 / 05$ \\
I9 & $15 / 04$ & $04 / 06$ & $06 / 06$ & $11 / 11$ & $05 / 04$ & $25 / 04$ & $30 / 11$ & $03 / 03$ & $11 / 05$ \\
I10 & $17 / 04$ & $05 / 06$ & $05 / 06$ & $11 / 11$ & $05 / 04$ & $24 / 04$ & $02 / 12$ & $03 / 03$ & $12 / 05$ \\
\hline
\end{tabular}


dispersal seed bank data were available for this population, resulting in a collected total of $\mathrm{N}=720$ seed bank samples. Seed bank samples were analysed using the seedling emergence method in a greenhouse (Thompson et al. 1997). For further details on plot design, field sampling and seed bank analysis see Kluth \& Bruelheide (2004a, c).

\section{Data analysis}

Subplot counting data and seedling counting data from seed bank analysis were summarized for each monitoring date and plot by calculating mean values. Mean densities were extrapolated to $1 \mathrm{~m}^{2}$ by dividing the mean values by the surface of samples, which were $0.09 \mathrm{~m}^{2}$ and $0.00238 \mathrm{~m}^{2}$ for subplot counting data and for seed bank samples, respectively. The fecundity of individuals was calculated by multiplying the maximum counted number of fruits and dissepiments in each vegetation period by 4 in order to obtain the seed number that was produced by one individual. Since densities were very low in the spring of 2000 in the Italian populations I3, I9 and I10, fecundity mean values were derived from less than ten values ( $\mathrm{n}=9, \mathrm{n}=9, \mathrm{n}=6$, respectively). Seed rain density was calculated by multiplying mean fecundity and mean adult plant density values obtained in the spring census. Since the temporal resolution of the seed bank population analyses was lower than that of the aboveground plant population, the survival of seeds in the seed bank and the incorporation of seeds into the seed bank could not be distinguished. We calculated the total transition into seed bank by dividing summer (post-dispersal) seed bank density by the sum of seed rain density and spring (pre-dispersal) seed bank density.

For calculating germination and survival rates, corrections were made at the subplot level. In the case of higher spring counts of individuals on a subplot compared to the preceding autumn count on the same subplot, the number of individuals in autumn was set equal to the number of plants of the spring census. This treatment appeared to be appropriate since plants that germinated in the spring were never observed: in particular not in the first study year, when the temporal resolution of field observations was higher. Discrepancies between spring and autumn census are rather due to later germination events in autumn or to counting errors in autumn when counting of $H$. petraea individuals was difficult, as plants were very small and often without secondary leaves. Counting was also hampered by dense vegetation or litter cover. The germination rate was then calculated as the mean of the corrected autumn density divided by the mean summer seed bank density. The survival rate was calculated as the ratio of mean spring density to the corrected mean autumn density. 
All transition steps are summarised by the total reproduction rate, calculated on the basis of mean spring population density of subsequent years by dividing the second year's spring density by the first year's spring density.

\section{Test statistics}

The mean population densities and calculated transition rates were $\log _{10}$ transformed. After $\log$ transformation, the data fulfilled the prerequisite of having a normal distribution in most cases. The transition rates were analysed by an autoregressive analysis of covariance strategy (ANCOVA) with density as continuous variable (covariate), country (representatives for central and peripheral populations, i.e. range position) and year as class variables. The stepwise ANCOVA strategy suggested by Littell et al. (1996:176) was adopted to a repeated measures design. For the repeated factor year, the $H$. petraea population was defined as subject and country was defined as group. The covariance matrix for repetitions was assumed to be unstructured. First, the data was fitted to a complete model, including all effects (the main factor country, the repeated factor year, the covariate density of the previous time step and all possible interactions). Then the model was simplified and optimised by omitting nonsignificant effects and controlling the model's performance using the Akaike's Information Criterion (AIC). For the simplifying strategy, first all non-significant interactions with the covariate density were omitted from the model statement (corresponding to the hypothesis that the slopes of the response variable and density are equal between the levels of the interacting factors). If the resulting model showed a non-significant effect of the covariate, density was omitted from the model, which then resulted in a repeated measures ANOVA and signifies that the slope of the response variable and density equals zero. In the next step, the interaction between country and repeated factor (country*year) was omitted, if it was not significant. Finally, the repeated factor was omitted, if it was not significant; this then resulted in a one-factorial repeated measures ANOVA. After stepwise simplification of the model in this way, we determined whether or not the AIC was reduced by this. In the case reduced AIC, the result of the simplified model is presented; otherwise, the result of the model of the previous step with the lower AIC is given. All calculations were done with proc mixed of the SAS/STAT software package (SAS Institute 2000b; Littell et al. 1996). For significant effects in the model, post hoc tests were performed using the lsmeans/pdiff option in the mixed procedure (proc mixed, SAS Institute 2000b). This provided estimates for each level or level combination obtained at the value of the overall mean of the covariate, if the covariate density had been retained in the model. Additionally, the 1smeans/pdiff results in estimates and 
$P$-values for the differences of least squares means between levels or level combinations. In all tests the significance level was $\alpha=0.05$.

Estimates for the slope of regression lines between transition and density were derived from the solution option in the mixed procedure for the selected model by the ANCOVA strategy if the covariate had not been omitted from the model (SAS Institute 2000b; Littell et al. 1996). In the figures regression lines are drawn on the basis of the estimates obtained using the final model.

This stepwise ANCOVA strategy directly reflects the hypotheses made in the introduction. Hypothesis 1 corresponds to the country effect. Hypothesis 2 corresponds to the effect of the interaction country*year. A significant country*year effect demonstrates the existence of inter-annual differences between the countries. If found to be significant, the magnitude of inter-annual variation of transition rates was calculated from differences of transition rates between years for each population and analysed by the means of ANOVA (repeated measures ANOVA for fecundity). If , the density effect or the country*density effect had been found to be significant in the preceding ANCOVA procedure and thus have been retained in the model, the evaluation of the magnitude of inter-annual variation has to take density-dependence into consideration. The transition rates were then adjusted by the estimated effect of density. For this purpose, the deviations of the observed transition rates to the predicted transition rates were calculated for each population. The resulting values of these deviations are densityadjusted differences in transition rates between years for each population. Hypothesis 3 corresponds to the interaction effect density*country. If found to be significant, the magnitude of density-dependence (i.e. estimated slope values) was compared between the two countries.

\section{Results}

\section{Fecundity}

There was no relationship between mean fecundity and mean spring density of adult plants (Fig. 2). The repeated measures ANCOVA strategy simplified the model to three factors. There was no general difference in the mean fecundity of the German and Italian H. petraea populations. The overall effect of the year and the interaction effect country*year were significant (Tab. 2). The highest median value of mean per capita fecundity over all populations was 86.4 seeds per individual $(n=19)$ in 1999 , the lowest was in 2000 (median $=21.2$, $\mathrm{n}=19$ ). In the last study year, the median of mean per capita fecundity was 50.0 seeds per individual $(n=19)$. The differences in fecundity between the study years were significantly 


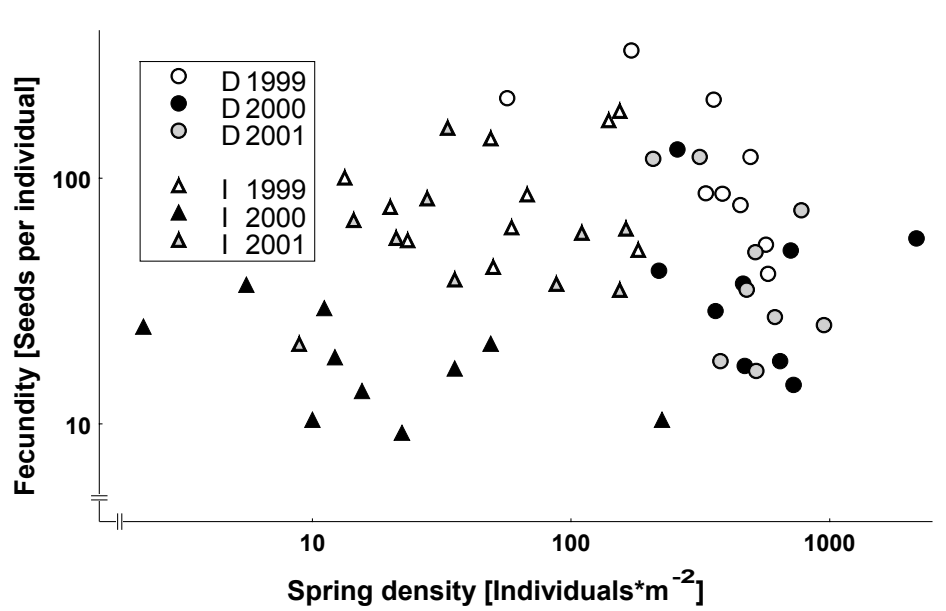

Fig. 2: Fecundity and adult spring density in peripheral (German, D) and central (Italian, I) populations of Hornungia petraea in three successive years $(1999,2000,2001)$.

Tab. 2: Results of simplified repeated measures ANCOVA for $\log _{10}$-transformed mean fecundity in peripheral and central Hornungia petraea populations. Country (main factor): peripheral (German) and central (Italian) populations, Year (repeated factor): 1999, 2000, 2001. Other factors could be omitted from the model.

\begin{tabular}{lccrr}
\hline Effect & df & Error df & \multicolumn{1}{c}{$F$} & \multicolumn{1}{c}{$P$} \\
\hline Country & 1 & 17 & 1.2 & 0.2993 \\
Year & 2 & 34 & 30.5 & $<0.0001$ \\
Country*Year & 2 & 34 & 3.8 & 0.0321 \\
\hline
\end{tabular}

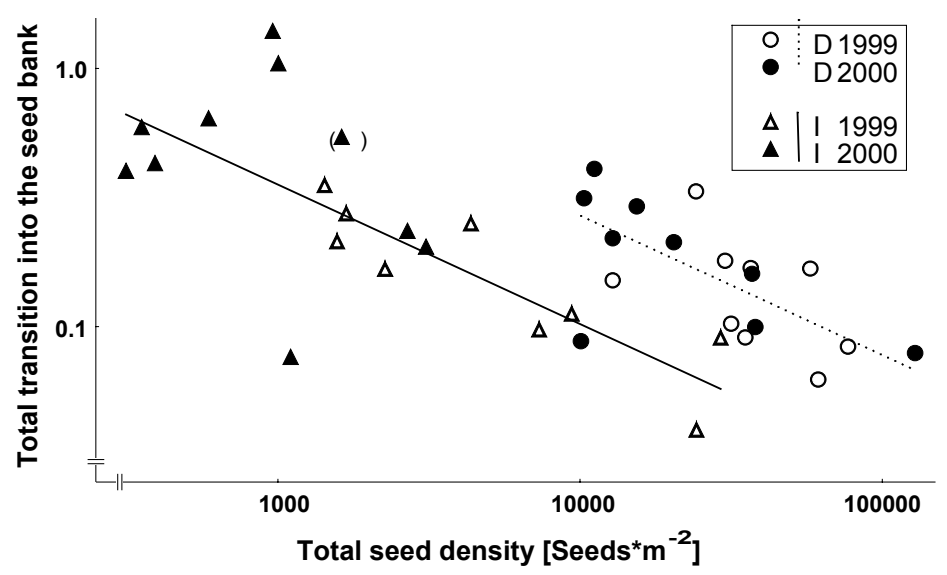

Fig. 3: Density-dependence of total transition into the seed bank in peripheral (German, D) and central (Italian, I) Hornungia petraea populations for two successive years $(1999,2000)$. Regressions are derived from estimates of repeated measures ANCOVA (Tab. 3). Total seed density $=$ sum of seed rain density and spring seed bank density.

Tab. 3: Results of simplified repeated measures ANCOVA for $\log _{10}$-transformed mean total transition into seed bank of peripheral and central Hornungia petraea populations. Country (main factor): peripheral (German) and central (Italian) populations), Density (covariate): $\log _{10}$-transformed mean density (mean number of seeds in pre-dispersal seed bank plus seed rain density).

\begin{tabular}{lcccr}
\hline Effect & df & Error df & $F$ & \multicolumn{1}{c}{$P$} \\
\hline Country & 1 & 16 & 19.2 & 0.0005 \\
Density & 1 & 17 & 58.0 & $<0.0001$ \\
\hline
\end{tabular}

influenced by the country. In Germany, the fecundity was significantly higher in 1999 (median $=86.6, \mathrm{n}=9)$ than the fecundity of the other two years (medians $=37.2$ and $35.2, \mathrm{n}=9$ for 2000 and 2001, respectively). In Italy, the median value of mean fecundity of 17.7 seeds per individual in the year 2000 was significantly lower than in the other two years (medians $=81.2$ and 58.6, n = 10 for 1999 and 2001, respectively). The repeated measures ANOVA for the differences of fecundity of populations between years yielded significantly higher inter-annual variation for the Italian plots than for the German plots $\left(F_{1,17}=13.2, P\right.$ $=0.0020$ ). Estimates of the interannual differences of fecundity were 0.323 and 0.627 for German and Italian, plots respectively.

Total transition into the seed bank

The density-dependence of the total transition into the seed bank is shown in Fig. 3. A transition rate of 1 means that $100 \%$ of the seeds present in the preceding time step (sum of seed rain density and spring seed bank density) were then detected in the 
subsequent seed bank samples. The statistical results of the log-log transformed data are given in Tab. 3. The repeated measures ANCOVA strategy simplified the model to only two factors. The transition into seed bank was significantly influenced by the country and by the covariate density. At a given density the transition into the seed bank was significantly higher in Germany than in Italy (Fig. 3). The regression lines therefore differ significantly in their intercept values (1.59 and 1.17 for Germany and Italy, respectively) but not in their slope values, which were estimated to be -0.540 .

This transition rate shows the importance of taking density into consideration when testing the effect of range position. A repeated measures ANOVA with a priori exclusion of density from the model detected no differences of the total transition into the seed bank between the two countries $\left(F_{1,16}=2.68, P=0.1211\right)$.

\section{Germination rate}

In general, the germination rate in the whole data set varied over a wide range (Fig. 4). From the seeds that were in the postdispersal seed bank $3 \%$ to $93 \%$ germinated $($ median $=12 \%)$. For the germination rate the repeated measures ANCOVA strategy could simplify the model to two factors. Both the country and the density significantly influenced the germination rate; there were higher germination rates in Germany than in Italy at a given density (Tab. 4, Fig. 4). The difference in the intercept values of the two regression lines was 0.609 for the log-log transformed data. The estimated slope was

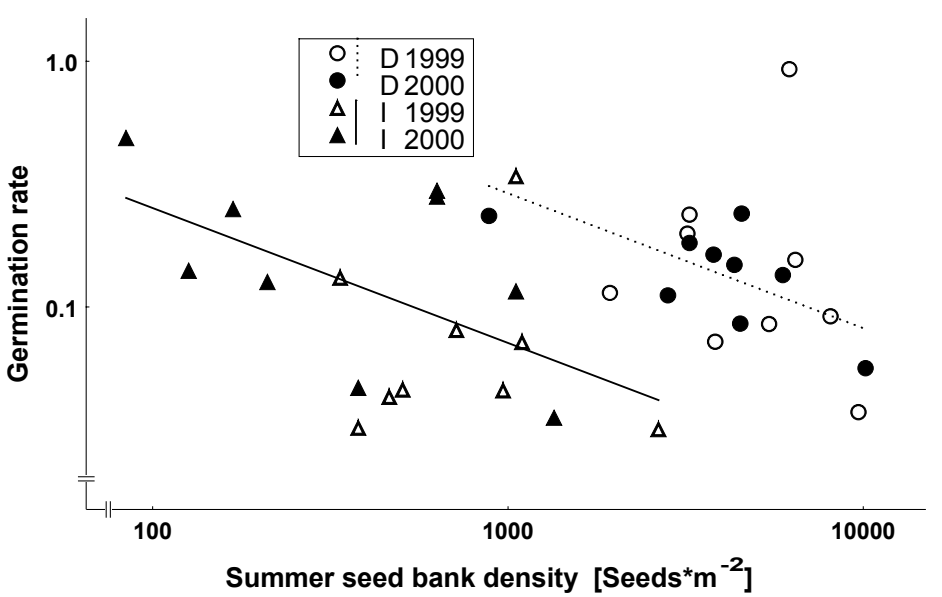

Fig. 4: Density-dependence of germination rate in peripheral (German, D) and central (Italian, I) Hornungia petraea populations for two successive years $(1999,2000)$. Regressions are derived from estimates of repeated measures ANCOVA (Tab. 4)

Tab. 4: Results of simplified repeated measures ANCOVA for $\log _{10}$-transformed mean germination rate of peripheral and central Hornungia petraea populations. Country: main factor, peripheral (German) and central (Italian) populations, Density (covariate): $\log _{10}$ of mean number of seeds in the seed bank in spring.

\begin{tabular}{lcccc}
\hline Effect & df & Error df & $F$ & $P$ \\
\hline Country & 1 & 16 & 13.34 & 0.0021 \\
Density & 1 & 17 & 16.94 & 0.0007 \\
\hline
\end{tabular}
-0.549 for the two countries. 


\section{Winter survival rate}

The winter survival rate exhibits a more complex pattern of density-dependence (Fig. 5). In Fig. 5 the winter survival rate is plotted against the autumn density of juvenile $H$. petraea plants. Table 5 presents the corresponding statistical results of the $\log -\log$ transformed data. The factors country, year and the interactions country*year and density*country significantly influenced the survival rates. The survival rates of plants were generally higher in German populations than in Italian populations. In Germany, 94\% (median of $\mathrm{n}=18$ ) of the germinated individuals survived and reached the reproductive stage;

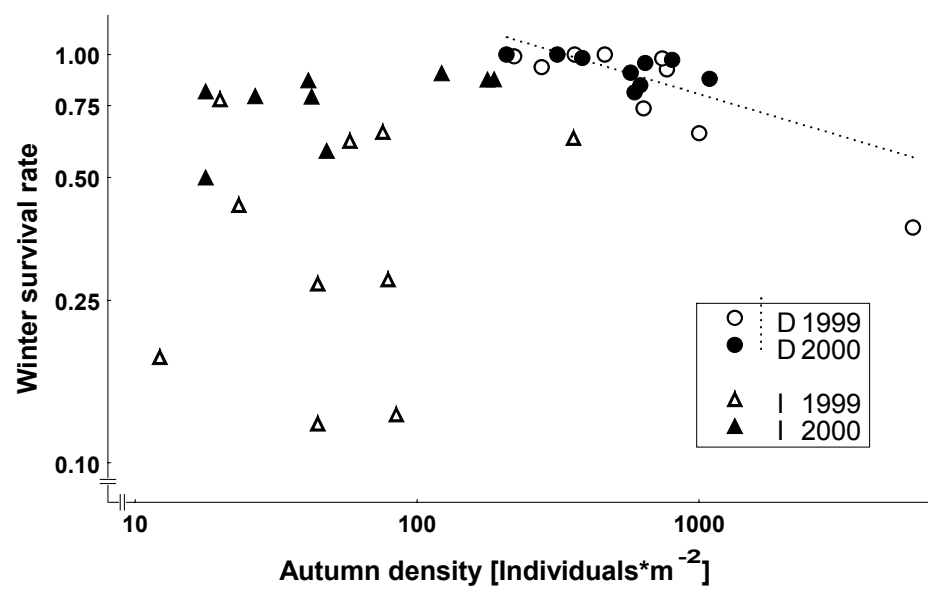

Fig. 5: Density-dependence of winter survival rate in peripheral (German, D) and central (Italian, I) Hornungia petraea populations for two successive years $(1999,2000)$. Regressions are derived from estimates of repeated measures ANCOVA (Tab. 5)

Tab. 5: Results of simplified repeated measures ANCOVA for $\log _{10}$-transformed mean winter survival rate of peripheral and central Hornungia petraea populations. Country (main factor): peripheral (German) and central (Italian) populations, Year (repeated factor): 1999,2000 , Density (covariate): $\log _{10}$ of mean number of seeds in spring seed bank.

\begin{tabular}{lcccr}
\hline Effect & df & Error df & $F$ & $P$ \\
\hline Country & 1 & 16 & 29.1 & $<0.0001$ \\
Year & 1 & 14 & 16.7 & 0.0011 \\
Country*Year & 1 & 14 & 11.0 & 0.0052 \\
Density & 1 & 14 & 0.4 & 0.5323 \\
Density *Country & 1 & 14 & 14.2 & 0.0021 \\
\hline
\end{tabular}

whereas in Italy the percentage was only $62 \%$ (median of $n=18$ ). The resulting estimates (at the log-log scale) for the survival rate were 0.033 and -0.242 for German and Italian plots, respectively. A general difference in the survival rate was detected between years with higher survival rates in 2000 (median $=87 \%, \mathrm{n}=18$ ) than in 1999 (median $=63 \%, \mathrm{n}=18$ ). Estimates for $\log _{10}$ survival rate were 0.0012 and -0.209 for the years 2000 and 1999, respectively. The difference in survival between countries was influenced by the repeated factor year. In Germany, 93\% (median) of the germinated individuals survived and reached the reproductive stage in 1999 , in Italy only $28 \%$. In the second study period this difference was much smaller but still significant (Germany: 95\%, Italy: 81\%). The inter-annual variation was higher on the Italian plots than on the German ones $\left(F_{1,16}=13.8, P=0.0019\right)$. Estimates of the inter-annual differences were 0.0815 and 0.428 for German and Italian plots, respectively. 
There was no general influence of density on the winter survival rate, but the interaction of density and country was significant. The regression line for the German plots was estimated as log-transition $=-0.182 * \log$-density +0.461 . The estimated regression line for Italian plots was not significant (log-transition $=0.129 * \log$-density -0.340$)$.

\section{Reproduction rate}

Fig. 6 shows the density-dependence of the reproduction rate of $H$. petraea. Table 6 gives the corresponding results of the simplified repeated measures ANCOVA for the log-log transformed data. All interactions with density were omitted from the model. Remaining significant effects on the reproduction rate were country, country*year and density.

In Italian populations, the reproduction rate varied over a wider range (0.04 to 15$)$ than in Germany $(0.24$ to 4.8$)$. At a given density the reproduction rate was significantly higher in German populations than in Italian populations. Estimates of the overall mean of the covariate were 0.252 and -0.197 for German and Italian plots, respectively. The common slope was estimated to be -0.272 . The interaction of the repeated factor year with country was significant. In 1999, the reproduction rate was significantly higher in Germany than in Italy. In Germany, the median reproduction rate was 1.4 in 1999 and in Italy the median was 0.64 . In contrast, in the year 2000 the reproduction rate in Italian populations was higher than in German populations (median values 1.8 and 0.95 for Germany and Italy, respectively). Analysing the inter-annual variation of reproduction rate by the means of the differences of reproduction rates between the years the difference between German and Italian plots

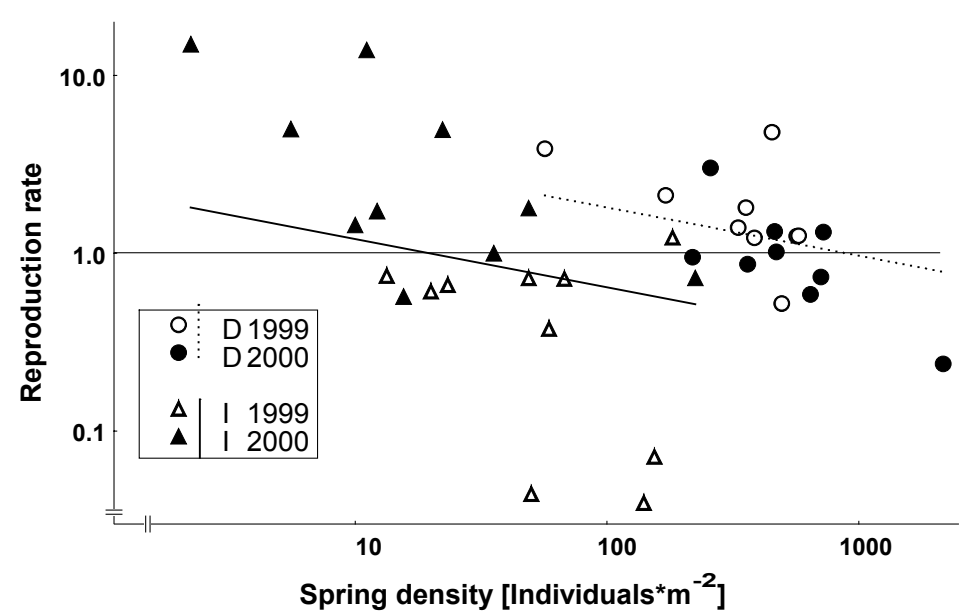

Fig. 6: Density-dependence of reproduction rate in peripheral (German, D) and central (Italian, I) Hornungia petraea populations for two successive years $(1999,2000)$. Regressions are derived from estimates of repeated measures ANCOVA (Tab. 6)

Tab. 6: Results of simplified repeated measures ANCOVA for $\log _{10}$-transformed mean reproduction rate of peripheral and central Hornungia petraea populations. Country (main factor): peripheral (German) and central (Italian) populations, Year (repeated factor): 1999, 2000, Density (covariate): $\log _{10}$ of mean number of seeds in spring seed bank

\begin{tabular}{lcccc}
\hline Effect & df & Error df & $F$ & $P$ \\
\hline Country & 1 & 17 & 24.2 & 0.0001 \\
Year & 1 & 16 & 3.0 & 0.1010 \\
Country*Year & 1 & 16 & 8.7 & 0.0095 \\
Density & 1 & 16 & 20.9 & 0.0003 \\
\hline
\end{tabular}


was not significant $\left(F_{1,17}=2.2, P=0.1533\right)$. Estimates of the inter-annual differences in reproduction rate were 0.433 and 0.960 for German and Italian plots, respectively.

\section{Summarised results of all transition rates}

Table 7 summarises all initially stated hypotheses for all transition rates in the life cycle of $H$. petraea. For all transition rates except fecundity, the expected effect of lower transition rates between life cycle stages for the central populations was found. The difference between the two countries was largest for germination (0.61). Fecundity was the only transition that showed no density-dependence. For both countries the steepest density-dependence was found for germination (-0.55). The country*year interaction was significant for the transition rates fecundity and winter survival rate. Both transition rates showed a higher inter-annual variation as expected for the Italian populations. These higher dynamics were not reflected in the reproduction rate, although the country*year interaction was significant. This significance results from a symmetric interaction, signifying an opposite trend between years of equal magnitude in the two countries. The winter survival rate was the only transition in the life cycle of $H$. petraea with significantly differing slopes as evidenced by a significant country*density effect.

Tab. 7: Summarised statistical results of hypotheses considering the transition rates in the life cycle of Hornungia petraea (transition rates $\log 10$-transformed). Country (main factor: peripheral (German, D) and central (Italian, I) populations), Year (repeated factor: 1999, 2000, fecundity also 2001) and density (covariate: $\log 10$ of mean density of previous life cycle stage) are the effects tested with repeated measures ANCOVA. After correcting transition rates for density effects, the dynamics were tested in a separate ANOVA for differences between years. Trends and estimates for differences and slope values are given. $* * * \mathrm{P}<0.001$, $* * \mathrm{P}<0.01, * \mathrm{P}<0.05$, n.s. $=$ not significant but included in the repeated measures ANCOVA, - = not significant but omitted in the repeated measures ANCOVA.

\begin{tabular}{|c|c|c|c|c|c|}
\hline \multirow[t]{2}{*}{ Transition } & \multicolumn{2}{|c|}{ Hypothesis 1} & \multicolumn{2}{|c|}{ Hypothesis 2} & \multirow{2}{*}{$\begin{array}{c}\text { Hypothesis } 3 \\
\text { Country*Density, } \\
\text { slopes }\end{array}$} \\
\hline & $\begin{array}{c}\text { Country, } \\
\text { trend, difference }\end{array}$ & $\begin{array}{l}\text { Density, } \\
\text { slope }\end{array}$ & Country*Year & $\begin{array}{c}\text { Dynamics, } \\
\text { trend, difference }\end{array}$ & \\
\hline Fecundity & n.s. & - & $*$ & $* *, I>D, 0.30$ & - \\
\hline $\begin{array}{l}\text { Total transition } \\
\text { ito the seedbank }\end{array}$ & $* * *, \mathrm{D}>\mathrm{I}, 0.42$ & $* * *,-0.54$ & - & & - \\
\hline Germination & $* *, \mathrm{D}>\mathrm{I}, 0.61$ & $* * *,-0.55$ & - & & - \\
\hline Winter survival & $* * *, \mathrm{D}>\mathrm{I}, 0.28$ & n.s. & $* *$ & $* *, I>D, 0.35$ & $* *, \mathrm{D}:-0.18, \mathrm{I}: 0.13$ \\
\hline Reproduction & $* * *, \mathrm{D}>\mathrm{I}, 0.45$ & $* * *,-0.27$ & $* *$ & n.s. & - \\
\hline
\end{tabular}

\section{Discussion}

The most ubiquitous phenomena of natural populations are their variability in numbers in space and time (Watkinson 1997; Lundberg et al. 2000) and their negative density-dependent regulation of population growth (Watkinson 1997; Silvertown \& Charlesworth 2001). Recently, these aspects have been increasingly taken into consideration in theoretical ecology 
and in model approaches (Lundberg et al. 2000; Watkinson et al. 2000; Maurer \& Taper 2002; Watkinson et al. 2003). Nevertheless, they are still neglected in empirical field studies, especially in those aiming at broad scales such as the scale of an entire species distribution.

\section{Range position and density-dependence}

Our first hypothesis assumed that the transition rates between life cycle stages would be lower in central populations if the observed lower population densities in central populations were taken into account. This expected effect was confirmed for most transition rates and would not have been evident without consideration of the density effect. ANOVAs that exclude the covariate density did not show these important differences between Italian and German populations as exemplified by the total transition into the seed bank.

Fecundity was the only transition that was neither density-dependent nor affected by range position. This result contradicts many other studies where fecundity exhibited a range position effect with reduced fecundity in peripheral populations (Pigott \& Huntley 1981; Carey et al. 1995; García et al. 2000; Dorken \& Eckert 2001; Jump \& Woodward 2003).

In addition, density-dependence of fecundity has been found in numerous potting experiments, field experiments and subplot observations in natural populations (e.g. Watkinson \& Harper 1978; Clay \& Shaw 1981; Jefferies et al. 1981; Watkinson 1990). In contrast to these studies, our results refer to whole natural populations. At the subplot level, density-dependence of fecundity was also detected for $H$. petraea populations and occurred more frequently in German populations than in Italian populations (C. Kluth \& H. Bruelheide, unpublished data). Obviously, these internal processes did not contribute to the regulation of the overall population density.

Especially in transition rates of the life stages, for which density-dependence has rarely been investigated in natural populations (seed bank incorporation rate and germination rate), we found strong density-dependence on the whole-population level. These transition rates might be of greater importance for population density-dependent regulation than generally assumed. Reduced incorporation rate (total transition into the seed bank) with increasing population density could be mediated by an increased seed predation (Watkinson \& Harper 1978; Watkinson et al. 1989; Crawley 1992). For the germination rate, density-dependence might be due to an inhibition of germination by neighbouring seeds (Murray 1998). In greenhouse experiments Rees \& Brown (1991) report inhibition of germination by conspecific seedlings for the Brassicaceae Sinapis arvensis. Recently, Stokes et al. (2004) found density- 
dependence to operate at the germination stage for the species Ulex gallii and U. minor in field experiments. At the community level Lortie \& Turkington (2002) observed that higher initial seed densities resulted in a reduced seedling emergence. We are not aware of any other studies showing density-dependent germination in non-manipulated natural populations.

In addition to the absolute strength of density-dependence of the germination rate, the range position effect was also most pronounced in this transition step. In consequence we conclude, that germination is of primary importance in the life cycle of $H$. petraea, both with respect to density-dependence and range position.

The results of all single transition steps were reflected in the total reproduction rate, for which we found a significant density-dependence and clear evidence for a reduced reproduction rate at a given density in Italian populations. When disregarding density-dependence, Stokes et al. (2004) did not find, in contrast to their expectations, a decline in population growth rates for Ulex gallii and U. minor populations at the distribution limit. The inclusion of densitydependence of seedling emergence and flowering within their matrix population models altered the resulting population size and structure.

\section{Range position and dynamics}

Our second hypothesis concerned the inter-annual variation of transition rates with regard to the range position. Both fecundity and winter survival rate varied from year to year independently of study region. The fecundity of trees is known to show spatially correlated masting even on broad scales (e.g. Koenig et al. 1999). To our knowledge, synchrony of fecundity has never been reported for plant life forms other than trees. The inter-annual variation of $H$. petraea's survival rate and fecundity suggests that the climatic conditions which determine seed production locally, also influence spatial patterns at broad scales. Although a certain climatic auto-correlation can be assumed between the two study regions, both fecundity and winter survival rate of $H$. petraea were additionally affected by the range position, with a higher inter-annual variation in the Italian populations than in German ones. Large inter-annual variation in fecundity and survival has been reported in a number of annual plants (e.g. Mack \& Pyke 1983; Symonides 1988; Kelly 1989; Thomas 1996). Therefore, increased year-to-year variation in these transitions might contribute to the observed pattern of lower population densities in the centre of the species distribution.

However, this was not reflected in the total reproduction rate as a summary over all single transition steps. The fact that pronounced year-to-year variation in single transition steps is 
not reflected in high inter-annual population fluxes is also known in other annual plants (Harper 1977; Symonides 1979; Silvertown 1982; Watkinson 1985). Nantel \& Gagnon (1999) found a larger inter-annual variation of vital rates and intrinsic growth rates in two populations each of Helianthus divaricatus and Rhus aromatica at the northern limit of the species distribution range than in two populations of each species at the central part of the distribution range. However, there was little difference in the density of the plants in the two types of populations (central vs. peripheral) and in both species (Gagnon, personal communication). This is in contrast to our results, where the higher year-to-year variation of fecundity and winter survival rate probably contributed to the reduced population densities in the central study region.

\section{Interaction of range position and density}

We found density-dependent self-thinning (Yoda et al. 1963) only in the denser German populations and not in the less dense Italian ones. This is in accordance with our third hypothesis, which assumed density-dependence would be more pronounced in the denser and peripheral German populations than in the Italian populations. We are not aware of any other empirical field study on changes in density-dependence in plant populations addressing this issue across large geographical scales. However, in contrast to our results, Williams et al. (2003) generally found no statistically significant change in density-dependence among geographic regions in their analysis of three small game species in North America, although there was a trend in smaller, peripheral populations to exhibit stronger density-dependence.

In our study, the density-dependence of German populations in winter survival rate was, however, low compared to the density-dependence of the other transition rates. Especially for the winter survival rate of Italian populations we found good correlations of survival with microclimatic data obtained from automatic weather stations (C. Kluth \& H. Bruelheide, unpublished data). The winter survival of $H$. petraea in Italy was correlated with the number of thawing-freezing cycles in the field. In accordance with the overall pattern of all single transitions, there was no change of density-dependence for total reproduction.

\section{Conclusions}

To our knowledge, this is the first study that tries to separate the impact of population density, range position and dynamics on demographic parameters retrieved from observational data in a single statistical model. The sampling procedure and statistical design were appropriate for the analysis of spatio-temporal variation of transition rates in the life cycle of $H$. petraea in 
that they controlled the variance of all investigated components, i.e. range-position, densitydependence and inter-annual variation. Theoretically, all these effects could influence each other. However, neither a three-fold interaction (country*year*density) nor an interaction between year and density was found at any stage in the species' life cycle. This means that density-dependence did not differ between repeated years or between countries in specific years. This outcome might have been different if the study period had been longer, since it is known, that populations might declined rapidly after a phase of stable demography with low population fluctuation (Watkinson 1990). In addition, dynamic processes of range contraction or expansion (Holt 2003) on even broader time scales would certainly also alter the observed pattern. However, the obtained results reflect the pattern of density of the two study regions (low densities in Italy, high densities in Germany) better than the traditional biogeographical view of an assumed pattern of low population densities in the periphery.

Our results have also implications on the expectations of the genetic structure of $H$. petraea, because the described demographical patterns should not only result in reduced population size but also in a pauperisation of genetic variance via genetic bottlenecks or genetic drift (Hartl \& Clark 1997; Futuyama 1998). However, the higher metapopulation dynamics in the central populations as assumed by Kluth \& Bruelheide (2004a) would probably act in the opposite direction by increasing the within-population genetic variance due to an increased gene flow between populations (Hastings \& Harrison 1994).

\section{Acknowledgements}

We thank Christoph Fühner, Stephanie Kluth, Holger Lieneweg, Ute Luginbühl and Gustav Schulz for their assistance in the field. We especially thank Leonardo Gubellini and Aldo Brilli-Cattarini from the Centro Ricerche Floristiche Marche for their assistance in locating Italian plots and their logistic help, and Alexandra Erfmeier and Stephanie Kluth for their valuable comments on the manuscript. This work was supported by a grant of the German Research Foundation DFG (BR 1698/2). 


\section{Literaturverzeichnis}

Aikio, S., Ranta, E., Kaitala, V. \& Lundberg, P. (2002) Seed bank in annuals: competition between banker and non-banker morphs. Journal of Theoretical Biology, 217, 341-349.

Antonovics, J. \& Levin, D.A. (1980) The ecological and genetic consequences of density-dependent regulation in plants. Annual Review of Ecology and Systematics, 11, 411-452.

Baker, H.G. (1989) Some aspects of the natural history of seed banks. Ecology of soil seed banks (eds M. A. Leck, V. T. Parker, \& R. L. Simpson), pp. 9-21. Academic Press, San Diego.

Ballard, L. (1958) Studies of dormancy in seeds or subterranean clover (Trifolium subterraneum L.). 1. Breaking of dormancy by $\mathrm{CO}_{2}$ and by activated carbon. Australian Journal of Biological Sciences., 11, 246-274.

Baskin, C.C. \& Baskin, J.M. (2001) Seeds: ecology, biogeography and evolution of dormancy and germination. Academic Press, San Diego.

Begon, M., Mortimer, M. \& Thompson, D.J. (1996) Population ecology. Blackwell, Oxford.

Bengtsson, K., Prentice, H.C., Rosén, E., Moberg, R. \& Sjögren, E. (1988) The dry alvar grasslands of Öland: ecological amplitudes of plant species in relation to vegetation composition. Acta Phytogeographica Suecica, 76, 21-46.

Benkert, D., Fukarek, F. \& Korsch, H. (1996) Verbreitungsatlas der Farn- und Blütenpflanzen Ostdeutschlands. Fischer, Jena.

Black, R. \& Prince, J. (1983) Fauna associated with the coral Pocillopora damicornis at the southern limit of its distribution in Western Australia. Journal of Biogeography, 10, 135-152.

Blackburn, T.M. \& Gaston, K.J. (2001) Local avian assemblages as random draws from regional pools. Ecography, 24, 50-58.

Blackburn, T.M. \& Gaston, K.J. (2003) Macroecology: concepts and consequences: the 43rd Annual Symposium of the British Ecological Society. Blackwell Science, Oxford.

Brown, J.H. (1984) On the relationship between abundance and distribution of species. American Naturalist, 124, 255-279.

Brown, J.H. \& Lomolino, M.V. (1998) Biogeography. Sinauer, Sunderland.

Brown, J.H., Mehlman, D.W. \& Stevens, G.C. (1995) Spatial variation in abundance. Ecology, 76, 2028-2043.

Brunner, E., Munzel, U. \& Puri, L.P. (1999) Rank-score tests in factorial designs with repeated measures. Journal of Multivariate Analysis, 70, 286-317.

Brunner, E. \& Puri, M.L. (2001) Nonparametric methods in factorial designs. Statistical Papers, 42, $1-52$.

Brussard, P.F. (1984) Geographic patterns and environmental gradients: the central-marginal model in Drosophila revisited. Annual Review of Ecology and Systematics, 15, 25-64.

Cabin, R.J., Marshall, D.L. \& Mitchell, R.J. (2000) The demographic role of soil seed banks. 2. Investigations of the fate of experimental seeds of the desert mustard Lesquerella fendleri. Journal of Ecology, 88, 293-302.

Caley, M.J. \& Schluter, D. (1997) The relationship between local and regional diversity. Ecology, 78, $70-80$.

Carey, P.D., Watkinson, A.R. \& Gerard, F.F.O. (1995) The determinants of the distribution and abundance of the winter annual grass Vulpia ciliata ssp. ambigua. Journal of Ecology, 83, 177-187.

Carson, H.L. (1959) Genetic conditions which promote or retard the formation of species. Cold Spring Harbor Symposia on Quantitative Biology, 24, 87-105. 
Carter, R.N. \& Prince, S.D. (1985) The geographical distribution of Prickly Lettuce (Lactuca serriola). I. A general survey of its habitats and performance in Britain. Journal of Ecology, 73, 2738.

Clay, K. \& Shaw, R. (1981) An experimental demonstration of density-dependent reproduction in a natural-population of Diamorpha smallii, a rare annual. Oecologia, 51, 1-6.

Colwell, R.K. (1997) EstimateS: Statistical estimation of species richness and shared species from samples. Version 5. User's guide and aplication published at: http://viceroy.eeb.uconn.edu/estimates

Colwell, R.K. \& Coddington, J.A. (1994) Estimating terrestrial biodiversity through extrapolation. Philosophical Transactions of the Royal Society (Series B), 345, 101-118.

Condit, R., Pitman, N., Leigh, E.G.Jr., Chave, J., Terborgh, J., Foster, R.B., Núñez, V., Aguliar, S., Valencia, R., Villa, G., Muller-Landau, H.C., Losos, E. \& Hubbell, S.P. (2002) Beta-diversity in tropical forest trees. Science, 295, 666-669.

Condit, R., Hubbell, S.P., Lafrankie, J.V., Sukumar, R., Manokaran, N., Foster, R.B. \& Ashton, P.S. (1996) Species-area and species-individual relationships for tropical trees: a comparison of three 50-ha plots. Journal of Ecology, 84, 549-562.

Cornell, H.V. (1999) Unsaturation and regional influences on species richness in ecological communities: A review of the evidence. Écoscience, 6, 303-315.

Cornell, H.V. \& Karlson, R.H. (1997) Local and regional processes as controlls of species richness. Spatial ecology: the role of space in population dynamics and population interactions (eds D. Tilman \& P. Kareiva), pp. 250-268. Princeton University Press, Princeton.

Cornell, H.V. \& Lawton, J.H. (1992) Species interations, local and regional processes, and limits to the richness of ecological communities: a theoretical perspective. Journal of Animal Ecology, 61, $1-12$.

Crawley, M.J. (1992) Seed predators and population dynamics. Seeds: the ecology of regeneration in plant communities (ed M. Fenner), pp. 157-191. CAB International, Walingford.

Crawley, M.J. \& Harral, J.E. (2001) Scale dependence in plant biodiversity. Science, 291, 864-868.

Dorken, M.E. \& Eckert, C.G. (2001) Severely reduced sexual reproduction in northern populations of a clonal plant, Decodon verticillatus (Lythraceae). Journal of Ecology, 89, 339-350.

Durka, W. (1999) Genetic diversity in peripheral and subcentral populations of Corrigiola litoralis L. (Illecebraceae). Heredity, 83, 476-484.

Eckert, C.G. \& Barrett, S.C.H. (1993) Clonal reproduction and patterns of genotypic diversity in Decodon verticillatus (Lythraceae). American Journal of Botany, 80, 1175-1182.

Edenhamn, P., Höggren, M. \& Carlson, A. (2000) Genetic diversity and fitness in peripheral and central populations of the European tree frog Hyla arborea. Hereditas, 133, 115-122.

Ehrlén, J. (2000) The dynamics of plant populations: does the history of individuals matter? Ecology, 81, 1675-1684.

European Council (1992) Council Directive 92/43/EEC of 21 May 1992 on the conservation of natural habitats and of wild fauna and flora. Journal officiel des Communautés européennes, L206, 22.7.1992.

Futuyama, D. (1998) Evolutionary biology. Sinauer Associates Inc., Massachusetts.

García, D., Zamora, R., Gómez, J.M., Jordano, P. \& Hódar, J.A. (2000) Geographical variation in seed production, predation and abortion in Juniperus communis throughout its range in Europe. Journal of Ecology, 88, 436-446.

Gaston, K.J. (1990) Patterns in the geographical ranges of species. Biological Reviews of the Cambridge Philosophical Society, 65, 105-129. 
Gaston, K.J., Blackburn, T.M., Greenwood, J.J.D., Gregory, R.D., Quinn, R.M. \& Lawton, J.H. (2000) Abundance-occupancy relationships. Journal of Applied Ecology, 37, 39-59.

Geißelbrecht-Taferner, L., Geißelbrecht, J. \& Mucina, L. (1997) Fine-scale spatial population patterns and mobility of winter-annual herbs in a dry grassland. Journal of Vegetation Science, 8, 209-216.

Gering, J.C. \& Crist, T.O. (2002) The alpha-beta-regional relationship: providing new insights into local-regional patterns of species richness and scale dependence of diversity components. Ecology Letters, 5, 433-444.

Godfray, H.C.J.J. \& Lawton, J.H. (2001) Scale and species numbers. Trends in Ecology and Evolution, 16, 400-404.

Haeck, J. \& Hengeveld, R. (1981) Changes in the occurrences of Dutch plant species in relation to geographical range. Biological Conservation, 19, 189-197.

Haeupler, H. \& Schönfelder, P. (1989) Atlas der Farn- und Blütenpflanzen der Bundesrepublik Deutschland. Ulmer, Stuttgart.

Hanski, I. \& Gilpin, M. (1991) Metapopulation dynamics: brief history and conceptual domain. Biological Journal of the Linnean Society, 42, 3-16.

Harper, J.L. (1977) Population biology of plants. Academic Press, London.

Hartl, D.L. \& Clark, A. (1997) Principles of population genetics. Sinauer Associates, Sunderland.

Hassell, M.P. (1975) Density-dependence in single-species populations. Journal of Animal Ecology, 44, 283-295.

Hastings, A. \& Harrison, S. (1994) Metapopulation dynamics and genetics. Annual Review of Ecology and Systematics, 25, 167-188.

Hengeveld, R. \& Haeck, J. (1982) The distribution of abundance. 1. Measurements. Journal of Biogeography, 9, 303-316.

Herben, T. (2000) Correlation between richness per unit area and the species pool cannot be used to demonstrate the species pool effect. Journal of Vegetation Science, 11, 123-126.

Herben, T., During, H.J. \& Krahulec, F. (1995) Spatiotemporal dynamics in mountain grasslands: Species autocorrelations in space and time. Folia Geobotanica et Phytotaxonomica, 30, 185-196.

Herben, T., Krahulec, F., Kovárová, M. \& Hadincová, V. (1990) Fine scale dynamics in a mountain grassland. Spatial proceses in plant comunities (eds F. Krahulec, A. D. Q. Agnew, S. Agnew, \& J. H. Willems), pp. 173-184. SPB Academic Publishing, The Hauge.

Hoffmann, A.A. \& Blows, M.W. (1994) Species borders: ecological and evolutionary perspectives. Trends in Ecology and Evolution, 9, 223-227.

Holt, R.D. (2003) On the evolutionary ecology of species' ranges. Evolutionary Ecology Research, 5, 159-178.

Huston, M.A. (1979) A general hypothesis of species diversity. American Naturalist, 113, 81-101.

Huston, M.A. (1994) Biological diversity: the coexistence of species on changing landscapes. Cambridge University Press, Cambridge.

Huston, M.A. (1999) Local processes and regional patterns: appropriate scales for understanding variation in the diversity of plants and animals. Oikos, 86, 393-401.

Jaccard, P. (1912) The distribution of the flora of the alpine zone. New Phytologist, 11, 37-50.

Jalas, J. \& Suominen, J. (1996) Atlas Florae Europaeae, Vol. 11: Cruciferae (Ricotia to Raphanus). Societas Biologica Fennica Vanamo, Helsinki.

Jefferies, R.L., Davy, A.J. \& Rudmik, T. (1981) Population biology of the salt marsh annual Salicornia europaea agg. Journal of Ecology, 69, 17-31. 
Jonas, C.S. \& Geber, M.A. (1999) Variation among populations of Clarkia unguiculata (Onagraceae) along altitudinal and latitudinal gradients. American Journal of Botany, 86, 333-343.

Jump, A.S. \& Woodward, F.I. (2003) Seed production and population density decline approaching the range-edge of Cirsium species. New Phytologist, 160, 349-358.

Kaya, Z. \& Temerit, A. (1994) Genetic structure of marginally located Pinus nigra var. pallasiana populations in central Turkey. Silvae Genetica, 43, 272-277.

Keating, K.A. \& Quinn, J.F. (1998) Estimating species richness: the Michaelis-Menten model revisted. Oikos, 81, 411-416.

Kelly, D. (1989) Demography of short-lived plants in chalk grassland. 1. Life cycle variation in annuals and strict biennials. Journal of Ecology, 77, 747-769.

Kikvidze, Z. (2000) Modelling species richness and diversity in grassland communities of the Central Caucasus. Oikos, 89, 123-127.

Kira, T., Ogawa, H. \& Sinozaki, K. (1953) Intraspecific competition among higher plants. 1. Competition-density-yield interrelationships in regularly dispersed populations. J.Inst.Polytech.Osaka City Univ., D 4, 1-16.

Kluth, C. \& Bruelheide, H. (2004a) Central and peripheral Hornungia petraea populations: patterns and dynamics. Journal of Ecology, submitted.

Kluth, C. \& Bruelheide, H. (2004b) Transition rates between life cycle stages in natural populations of the annual plant Hornungia petraea: The combined effect of density-dependence, range position and inter-annual dynamics. Oecologia, submitted.

Kluth, C. \& Bruelheide, H. (2004c) Using standardised sampling designs from population ecology to assess biodiversity patterns of therophyte vegetation across scales. Journal of Biogeography, 31, 363-377.

Knight, T.M. (2003) Floral density, pollen limitation, and reproductive success in Trillium grandiflorum. Oecologia, 137, 557-563.

Koenig, W.D., Knops, J.M.H., Carmen, W.J. \& Stanback, M.T. (1999) Spatial dynamics in the absence of dispersal: acorn production by oaks in central coastal California. Ecography, 22, 499506.

Korneck, D., Schnittler, M. \& Vollmer, I. (1996) Rote Liste der Farn- und Blütenpflanzen (Pteridophyta et Spermatophyta) Deutschlands. Schriftenreihe für Vegetationskunde, 28, 21-187.

Korsch, H., Westhus, W. \& Zündorf, H.J. (2002) Verbreitungsatlas der Farn- und Blütenpflanzen Thüringens. Weissdorn, Jena.

Lammi, A., Siikamäki, P. \& Mustajärvi, K. (1999) Genetic diversity, population size, and fitness in central and peripheral populations of a rare plant Lychnis viscaria. Conservation Biology, 13, 10691078.

Lawton, J.H. (1993) Range, Population Abundance and Conservation. Trends in Ecology and Evolution, 8, 409-413.

Lawton, J.H. (1999) Are there general laws in ecology? Oikos, 84, 177-192.

Lesica, P. \& Allendorf, F.W. (1995) When are peripheral populations valuable for conservation? Conservation Biology, 9, 753-760.

Lewontin, R.C. (1974) The genetic basis of evolutionary change. Columbia University Press, New York.

Littell, R.C., Milliken, G.A., Stroup, W.W. \& Wolfinger, R.D. (1996) SAS $S^{\circledR}$ system for mixed models. SAS Institute Inc., Cary, NC.

Lönn, M. \& Prentice, H.C. (2002) Gene diversity and demographic turnover in central and peripheral populations of the perennial herb Gypsophila fastigiata. Oikos, 99, 489-498. 
Loreau, M. (2000) Are communities saturated? On the relationship between alpha, beta and gamma diversity. Ecology Letters, 3, 73-76.

Lortie, C.J. \& Turkington, R. (2002) The effect of initial seed density on the structure of a desert annual plant community. Journal of Ecology, 90, 435-445.

Lundberg, P., Ranta, E., Ripa, J. \& Kaitala, V. (2000) Population variability in space and time. Trends in Ecology and Evolution, 15, 460-464.

MacArthur, R.H. \& Wilson, E.O. (1967) The theory of island biogeography. Princeton University Press, Princeton, NJ.

Mack, R.N. \& Pyke, D.A. (1983) The demography of Bromus tectorum: variation in time and space. Journal of Ecology, 71, 69-93.

Magurran, A.E. (1988) Ecological diversity and its measurement. Princeton University Press, Princeton.

Maurer, B.A. \& Taper, M.L. (2002) Connecting geographical distributions with population processes. Ecology Letters, 5, 223-231.

Mawdsley, N. (1996) The theory and practice of estimating regional species richness from local samples. Tropical Rainforest Research (ed D. S. Edwards), pp. 193-214. Kluwer Academic publishers.

Mayr, E. (1965) Animal species and evolution. Belknap Press.

McCauley, R.A. \& Ballard, H.E.Jr. (2002) Inferring nativity and biogeographic affinities of central and marginal populations of Froelichia floridana (Amaranthaceae) from Inter-Simple Sequence Repeat (ISSR) markers. Journal of the Torrey Botanical Society, 129, 311-325.

McCue, K.A. \& Holtsford, T.P. (1998) Seed bank influences on genetic diversity in the rare annual Clarkia springvillensis (Onagraceae). American Journal of Botany, 85, 30-36.

McGill, B. \& Collins, C. (2003) A unified theory for macroecology based on spatial patterns of abundance. Evolutionary Ecology Research, 5, 469-492.

Metcalf, A.E., Nunney, L. \& Hyman, B.C. (2001) Geographic patterns of genetic differentiation within the restricted range of the endangered Stephens' kangaroo rat Dipodomys stephensi. Evolution, 55, 1233-1244.

Murray, B.R. (1998) Density-dependent germination and the role of seed leachate. Australian Journal of Ecology, 23, 411-418.

Nantel, P. \& Gagnon, D. (1999) Variability in the dynamics of northern peripheral versus southern populations of two clonal plant species, Helianthus divaricatus and Rhus aromatica. Journal of Ecology, 87, 748-760.

Nekola, J.C. \& White, P.S. (1999) The distance decay of similarity in biogeography and ecology. Journal of Biogeography, 26, 867-878.

Nunney, L. (2002) The effective size of annual plant populations: the interaction of a seed bank with fluctuating population size in maintaining genetic variation. American Naturalist, 160, 195-204.

Oberdorfer, E. (1978) Süddeutsche Pflanzengesellschaften. Fischer, Stuttgart.

Oberdorfer, E. (1983) Pflanzensoziologische Exkursionsflora. Ulmer, Stuttgart.

Orth, R.J., Fishman, J.R., Harwell, M.C. \& Marion, S.R. (2003) Seed-density effects on germination and initial seedling establishment in eelgrass Zostera marina in the Chesapeake Bay region. Marine Ecology Progress Series, 250, 71-79.

Oyama, K. (1998) Genetic differentiation among populations of Arabis serrata (Brassicaceae) along its geographic distribution. Plant Systematics and Evolution, 213, 91-102.

Palmblad, I.G. (1968) Competition in experimental populations of weeds with emphasis on regulation of population size. Ecology, 49, 26-34. 
Pärtel, M., Moora, M., Zobel, M. \& Abbott, R.J. (2001) Variation in species richness within and between calcareous (alvar) grassland stands: the role of core and satellite species. Plant Ecology, 157, 203-211.

Pärtel, M., Zobel, M., Zobel, K. \& van der Maarel, E. (1996) The species pool and its relation to species richness: evidence from Estonian plant communities. Oikos, 75, 111-117.

Pignatti, S. (1997) Flora d'Italia. Edagricole, Bologna.

Pigott, C.D. \& Huntley, J.P. (1981) Factors controlling the distribution of Tilia cordata at the northern limits of its geographical range. 3. Nature and causes of seed sterility. New Phytologist, 87, 817839.

Preston, F.W. (1960) Time and space and the variation of species. Ecology, 41, 785-790.

Prince, S.D., Carter, R.N. \& Dancy, K.J. (1985) The geographical distribution of Prickly Lettuce (Lactuca serriola). Characteristics of populations near its distribution limit in Britain. Journal of Ecology, 73, 39-48.

Pulliam, H.R. (2000) On the relationship between niche and distribution. Ecology Letters, 3, 349-361.

Qian, H., Klinka, K. \& Kayahara, G.J. (1998) Longitudinal patterns of plant diversity in the North American boreal forest. Plant Ecology, 138, 161-178.

Raaijmakers, J.G.W. (1987) Statistical analysis of the Michaelis-Menten equation. Biometrics, 43, 793-803.

Rees, M. (1994) Delayed germination of seeds: a look at the effects of adult longevity, the timing of reproduction, and population age/stage structure. American Naturalist, 144, 43-64.

Rees, M. \& Brown, V.K. (1991) The effect of established plants on recruitment in the annual forb Sinapis arvensis. Oecologia, 87, 58-62.

Rehfeldt, G.E. (1999) Systematics and genetic structure of Ponderosae taxa (Pinaceae) inhabiting the mountain islands of the Southwest. American Journal of Botany, 86, 741-752.

Rescia, A.J., Schmitz, M.F., Martín de Agar, P., de Pablo, C.L. \& Pineda, F.D. (1997) A fragmented landscape in northern Spain analyzed at different spatial scales: Implications for management. Journal of Vegetation Science, 8, 343-352.

Reusch, T.B.H. (2003) Floral neighbourhoods in the sea: how floral density, opportunity for outcrossing and population fragmentation affect seed set in Zostera marina. Journal of Ecology, 91, 610-615.

Richardson, D.M., Cowling, R.M., Lamont, B.B. \& van Hensbergen, H.J. (1995) Coexistence of Banksia species in southwestern Australia: the role of regional and local processes. Journal of Vegetation Science, 6, 329-342.

Ricklefs, R.E. (1987) Community diversity: relative roles of local and regional processes. Science, 235, 167-171.

Safriel, U.N., Volis, S. \& Kark, S. (1994) Core and peripheral populations and global climate change. Israel Journal of Plant Sciences, 42, 331-345.

Sagarin, R.D. \& Gaines, S.D. (2002a) Geographical abundance distributions of coastal invertebrates: using one-dimensional ranges to test biogeographic hypotheses. Journal of Biogeography, 29, $985-$ 997.

Sagarin, R.D. \& Gaines, S.D. (2002b) The 'abundant centre' distribution: to what extent is it a biogeographical rule? Ecology Letters, 5, 137-147.

SAS Institute (2000a) SAS procedures guide, version 8. SAS Institute Inc., Cary, NC.

SAS Institute (2000b) SAS/STAT user's guide, version 8. SAS Institute Inc., Cary, NC. 
Schmidt, K.P. \& Levin, D.A. (1985) The comparative demography of reciprocally sown populations of Phlox drummondii Hook. I. Survivorships, fecundities, and finite rates of increase. Evolution, 39, 396-404.

Schoolmaster, D.R.Jr. (2001) Using the Dispersal Assembly Hypothesis to predict local species richness from the relative abundance of species in the regional species pool. Community Ecology, 2, 35-40.

Shea, K.L. \& Furnier, G.R. (2002) Genetic variation and population structure in central and isolated populations of balsam fir, Abies balsamea (Pinaceae) 2002 89: 783-791. American Journal of Botany, 89, 783-791.

Shmida, A. \& Wilson, M.V. (1985) Biological determinants of species diversity. Journal of Biogeography, 12, 1-20.

Siikamäki, P. \& Lammi, A. (1998) Fluctuating asymmetry in central and marginal populations of Lychnis viscaria in relation to genetic and environmental factors. Evolution, 52, 1285-1292.

Silvertown, J.W. (1982) Introduction to plant population ecology. Longman, London.

Silvertown, J.W. \& Charlesworth, D. (2001) Introduction to plant population biology. Blackwell Science, Oxford.

Silvertown, J.W. \& Lovett Doust, J. (1993) Introduction to plant population ecology. Blackwell Scientific Publications, Oxford.

Srivastava, D.S. (1999) Using local-regional richness plots to test for species saturation: pitfalls and potentials. Journal of Animal Ecology, 68, 1-16.

Stokes, K.E., Bullock, J.M. \& Watkinson, A.R. (2004) Population dynamics across a parapatric range boundary: Ulex gallii and Ulex minor. Journal of Ecology, 92, 142-155.

Sykes, M.T., van der Maarel, E., Peet, R.K. \& Willems, J.H. (1994) High species mobility in speciesrich plant communities: an inercontinental comparisson. Folia Geobotanica et Phytotaxonomica, 29, 439-448.

Symonides, E. (1979) The structure and population dynamics of psammophytes on inland dunes. 3. Populations of compact psammophyte communities. Polish Journal of Ecology, 27, 235-257.

Symonides, E. (1988) Population dynamics of annual plants. Plant population ecology: the 28th Sympossium of the British Ecological Society (eds A. J. Davy, M. J. Hutchings, \& A. R. Watkinson), pp. 221-248. Blackwell.

Thomas, C.D., Cameron, A., Green, R.E., Bakkenes, M. et al. (2004) Extinction risk from climate change. Nature, 427, 145-148.

Thomas, L.P. (1996) Population ecology of a winter annual (Lesquerella filiformis Rollins) in a patchy environment. Natural Areas Journal, 16, 216-226.

Thompson, K. \& Grime, J.P. (1979) Seasonal variation in the seed banks of herbaceous species in ten contrasting habitats. Journal of Ecology, 67, 893-921.

Thompson, K., Bakker, J.P. \& Bekker, R.M. (1997) The soil seed banks of North West Europe: methodology, density and longevity. Cambridge University Press, Cambridge.

Thórhallsdóttir, T.E. (1990) The dynamics of Grassland community: a simulatanious investigation of spatial and temporal heterogeneity at various scales. Journal of Ecology, 78, 884-908.

Tutin, T.G. (1968) Flora Europea. Cambridge University Press, Cambridge.

Tyler, T. (2002) Large-scale geographic patterns of genetic variation in Melica nutans, a widespread Eurasian woodland grass. Plant Systematics and Evolution, 236, 73-87.

Van der Maarel, E. \& Sykes, M.T. (1993) Small-scale plant species turnover in a limestone grassland: the carousel model and some comments on the niche concept. Journal of Vegetation Science, $\mathbf{4}$, 179-188. 
Van Rossum, F., Meerts, P., Gratia, E. \& Tanghe, M. (1999) Ecological amplitude in Silene nutans in relation to allozyme variation at the western margin of its distribution. Journal of Vegetation Science, 10, 253-260.

Van Rossum, F., Vekemans, X., Meerts, P., Gratia, E. \& Lefèbvre, C. (1997) Allozyme variation in relation to ecotypic differentiation and population size in marginal populations of Silene nutans. Heredity, 78, 552-560.

Van Tooren, B.F. (1988) The fate of seeds after dispersal in chalk grassland: the role of the bryophyte layer. Oikos, 53, 41-48.

Vandermeer, J.H. \& Goldberg, D.E. (2003) Population ecology: first principles. Princeton University Press, Princeton.

Wagner, H.H., Wildi, O. \& Ewald, K.C. (2000) Additive partitioning of plant species diversity in an agricultural mosaic landscape. Landscape Ecology, 15, 219-227.

Walter, H. \& Straka, H. (1970) Arealkunde (Floristisch-historische Geobotanik). Ulmer, Stuttgart.

Watkinson, A.R. (1985) On the abundance of plants along an environmental gradient. Journal of Ecology, 73, 569-578.

Watkinson, A.R. (1990) The population dynamics of Vulpia fasciculata: a nine-year study. Journal of Ecology, 78, 196-209.

Watkinson, A.R. (1997) Plant population dynamics. Plant ecology (ed M. J. Crawley), pp. 359-400. Blackwell Science, Oxford.

Watkinson, A.R., Gill, J. \& Freckleton, R.P. (2003) Macroecology and microecology: linking largescale patterns of abundance to population processes. Perspectives on large scale ecological processes (eds K. J. Gaston \& T. M. Blackburn), Blackwell Publishing, Oxford.

Watkinson, A.R. \& Harper, J.L. (1978) Demography of a sand dune annual: Vulpia fasciculata. 1. Natural regulation of populations. Journal of Ecology, 66, 15-33.

Watkinson, A.R., Lonsdale, W.M. \& Andrew, M.H. (1989) Modeling the population-dynamics of an annual plant Sorghum intrans in the wet-dry tropics. Journal of Ecology, 77, 162-181.

Watkinson, A.R., Freckleton, R.P. \& Forrester, L. (2000) Population dynamics of Vulpia ciliata: regional, patch and local dynamics. Journal of Ecology, 88, 1012-1029.

Whittaker, R.H. (1972) Evolution and measurement of species diversity. Taxon, 21, 213-251.

Whittaker, R.H. (1977) Evolution of species diversity in land communities. Evolutionary Biology, 10, $1-67$.

Whittaker, R.J., Willis, K.J. \& Field, R. (2001) Scale and species richness: towards a general, hierarchical theory of species diversity. Journal of Biogeography, 28, 453-470.

Williams, C.K., Ives, A.R. \& Applegate, R.D. (2003) Population dynamics across geographical ranges: time-series analyses of three small game species. Ecology, 84, 2654-2667.

Willis, K.J. \& Whittaker, R.J. (2002) Species diversity - scale matters. Science, 295, 1245-1248.

Wilson, J.B., Ronghua, Y., Mark, A.F. \& Agnew, A.D.Q. (1991) A test of the low marginal variance (LMV) theory, in Leptospermum scoparium (Myrtaceae). Evolution, 45, 780-784.

Wright, S. (1921) Systems of mating. Genetics, 6, 111-178.

Yoda, K., Kira, T., Ogawa, H. \& Hozumi, K. (1963) Self-thinning in overcrowded pure stands under cultivated and natural conditions. Journal of Biology, Osaka City University, 14, 107-129.

Zobel, K. \& Liira, J. (1997) A scale-independent approach to the richness vs biomass relationship in ground-layer plant communities. Oikos, 80, 325-332. 


\section{Zusammenfassung}

Hornungia petraea ist eine winterannuelle Brassicaceae mit submediterraner-subatlantischer Verbreitung. Anhand dieses Untersuchungsobjektes wurden unterschiedliche Aspekte von Biodiversitätsmustern und Demographie über verschiedene raum-zeitliche Skalen untersucht. Das höchste untersuchte Skalenniveau war der Vergleich zentraler und peripherer Populationen über die gesamte geographische Verbreitung. Als zentrales Untersuchungsgebiet wurde Mittelitalien (Marken, Umbrien) gewählt. Stellvertretend für periphere Populationen war eine Exklave am nordöstlichen Arealrand in Mitteldeutschland (Thüringen, SachsenAnhalt) gewählt worden. Die hierarchisch nächstniedrigere Skalenebene stellten die einzelnen Populationen von $H$. petraea (Plots) dar. In jedem Untersuchungsgebiet wurden zehn Populationen entlang eines $100 \mathrm{~km}$ langen Transektes ausgewählt. Die niedrigste untersuchte Skalenebene waren zufällig innerhalb dieser Populationen ausgewählte Kleinquadrate (Subplots). Über drei Vegetationsperioden von H. petraea wurden die Individuenzahl und die Populationsdichte aller Lebensstadien einschließlich der Samenbank bestimmt.

Anhand dieses formalisierten hierarchischen Beprobungsdesigns wurden Biodiversitätsmuster über die verschiedenen Skalenebenen analysiert und Biodiversitäts-Indices für die verschiedenen Skalen miteinander und mit Charakteristika der Untersuchungsflächen in Beziehung gesetzt. Gängige Diversitäts-Indices für $\alpha$-, $\beta$ - und $\gamma$-Diversität (unabhängig von der betrachteten Skalenebene) wurden mit Diversitäts-Indices verglichen, die sich aus der Auswertung von Artenakkumulationskurven über die Michaelis-Menten-Gleichung ergeben. Die zu erwartende Übereinstimmung der Ergebnisse wurde hergeleitet und die Vorteile dieser Methode zur einheitlichen Auswertung von Biodiversität über verschiedene Skalenebenen hinweg herausgestellt. Für das Untersuchungsobjekt selbst ergab sich, dass erstens die Art auf dem kleinsten betrachteten Skalenniveau der Subplots im Arealzentrum ebenso viele direkt benachbarte Arten hat wie am Arealrand, d.h. der Artenreichtum gleich war. Zweitens zeigte sich, dass auf dem Niveau gesamter Populationen im Arealzentrum mehr Arten vorkommen als am Arealrand und dass drittens die italienischen Untersuchungsflächen sich in ihrer Artenzusammensetzung stärker voneinander unterschieden als deutsche Flächen. Das heißt, dass $H$. petraea im italienischen zentralen Untersuchungsgebiet in einer größeren Anzahl unterschiedlicher Habitate vorkommt als im peripheren deutschen Untersuchungsgebiet.

Aus dem sogenannten „central-marginal model“ ergeben sich Annahmen hinsichtlich der Populationsdichten für das Skalenniveau der gesamten geographischen Verbreitung von Arten. Nach diesem Modell ist davon auszugehen, dass periphere Populationen geringere 
Dichten aufweisen als Populationen im Zentrum des Verbreitungsgebietes einer Art. An Pflanzen wurde diese Annahme bisher selten direkt untersucht. In dieser Untersuchung wurden alle Lebensstadien der Art H. petraea im Hinblick auf die Vorhersagen des Modells überprüft. Die anhand des streng hierarchischen Beprobungsdesigns gewonnenen Daten wurden mittels einer der Methode angepassten Varianzanalyse ausgewertet. Dabei können die Effekte der verschiedenen Faktoren des Landes, der im Land verschachtelten Populationen und die zeitliche Wiederholung - adäquat getrennt und ihr Einfluss auf die Dichte des entsprechenden Lebensstadiums verglichen werden. Auf der Zeitskala werden sowohl interannuelle als auch saisonale Dynamiken berücksichtigt. Anders als erwartet zeigte sich für alle Lebensstadien im deutschen Untersuchungsgebiet eine - verglichen mit dem italienischen Gebiet - höhere Populationsdichte. Der Einfluss der Population war geringer als der Einfluss der Lage im Verbreitungsgebiet. Die stärkste interannuelle Dynamik wies die Fekundität auf. In der saisonalen Dynamik sind die Unterschiede der Samenbankpopulationen besonders deutlich. Diese scheinen die Hauptursache für die unterschiedlichen Dichtemuster von $H$. petraea zu sein, da bei den zentralen Populationen deutlich weniger Samen nach ihrer Ausbreitung in die Samenbank inkorporiert werden als bei peripheren Populationen. In Verbindung mit Beobachtungen zur Neugründung von Populationen lassen diese Ergebnisse auf eine höhere Metapopulationsdynamik im italienischen zentralen Untersuchungsgebiet schließen.

Weitere mögliche demographische Ursachen wurden auf dem Skalenniveau der gesamten Populationen untersucht, wobei alle Übergangsraten im Lebenszyklus von $H$. petraea genauer betrachtet wurden. Die zu erwartenden Effekte Dichteabhängigkeit und zeitliche Dynamik sowie der Effekt des Faktors Land auf die Übergangsraten wurden in einem adäquaten statistischen Modell berücksichtigt. Bei gegebenen Dichten waren Inkorporationsrate, Keimrate und Winterüberlebensrate in den peripheren Populationen höher als in zentralen Populationen. Besonders dichteabhängig waren Keimrate und Inkorporationsrate, deren Dichteabhängigkeit in der Literatur bisher wenig Eingang gefunden hat. Es erwies sich, dass die Dynamik der Übergangsraten bei den italienischen Populationen stärker war als bei den deutschen Populationen, was eine zusätzliche Erklärung der geringeren Populationsdichten im Arealzentrum sein kann. Ohne die Berücksichtigung der Dichteabhängigkeit hätte der Unterschied in den Übergangsraten zwischen zentralen und peripheren Populationen nicht gezeigt werden können.

Die Ergebnisse dieser Untersuchung verändern die Erwartungen zur genetischen Struktur der Populationen. Erstens legt die höhere Anzahl unterschiedlicher von H. petraea besiedelter 
Habitate in Italien den Schluss nahe, dass die genetische Diversität zwischen den italienischen Populationen größer ist als die zwischen den deutschen Populationen. Zweitens kann erwartet werden, dass die geringeren Populationsdichten in Italien die genetische Varianz innerhalb der Populationen verringert. Drittens führt jedoch die höhere Metapopulationsdynamik im italienischen Untersuchungsgebiet zu einem höheren genetischen Austausch zwischen den Populationen. Derartige Zusammenhänge zeigen die Wichtigkeit der Implementierung demographischer Gegebenheiten, wie z.B. Populationsdichten, Populationsdynamik und Dichteabhängigkeit, in das „,central-marginal model“ und könnten damit auch erklären, warum eine reduzierte molekulargenetische Varianz am Arealrand bisher nicht als generelles Muster bestätigt werden konnte. 


\section{Danksagung}

Ich danke Prof. Dr. Helge Bruelheide für die Überlassung des Themas. Besonders dankbar bin ich ihm für seine Diskussionsbereitschaft und seine Kommentare zu den Manuskripten, die dazu beigetragen haben, aus teils verwickelten und verknoteten roten Knäueln einen Faden und aus entsprechenden Sätzen den Sinn herauszupräparieren.

Prof. Dr. Michael Runge danke ich für die freundliche Übernahme des Korreferates. Prof. Dr. Christoph Leuschner danke ich für die Aufnahme in seine Arbeitsgruppe und die Überlassung eines Arbeitsplatzes.

Prof. Dr. Thomas Friedl, Julia Müller, Dr. Dominik Hepperle und Elke Zufall-Roth danke ich für die freundliche Unterstützung bei den AFLP-Analysen.

Prof. Dr. Edgar Brunner danke ich dafür, dass er mich bei der statistischen Auswertung der Daten unterstützt hat.

Bei Dr. Leonardo Gubellini vom Centro Ricerche Floristiche Marche in Pesaro bedanke ich mich für die außergewöhnliche Gastfreundschaft an seinem Institut und für die praktische Hilfe bei organisatorischen Problemen im Zusammenhang mit der Etablierung der Untersuchungsflächen in Italien. Ihm sowie Prof. Dr. Aldo Brilli-Cattarini vom Centro Ricerche Floristiche Marche gilt außerdem mein besonderer Dank dafür, dass sie mir bei der Bestimmung der Pflanzen der italienischen Untersuchungsflächen geholfen haben. Dr. Ute Jandt danke ich für Hilfe bei der Bestimmung schwieriger deutscher Kleinarten.

Für die Betretungserlaubnis und ihre unkomplizierte Hilfsbereitschaft danke ich den Zuständigen für den Parco nazionale dei Monti Sibillini, den Parco Naturale Regionale Gola della Rossa e di Frasassi, den Kyffhäuser Naturpark und für die Naturschutzgebiete der anderen deutschen Untersuchungsflächen.

Der Deutschen Forschungsgemeinschaft danke ich für die finanzielle Unterstützung des Projekts.

Bei allen meinen Studentischen Hilfskräften, den Gärtnern des Botanischen Gartens Sektion Ökologie Göttingen und des Orto Botanico in Pesaro und bei den Technischen Angestellten Marianne Gscheidlen und Hartmut Wildberger bedanke ich mich für ihre freundliche, engagierte Mitarbeit bei der Erhebung der Daten der Klimaschrankexperimente, der Betreuung der Common gardenExperimente und der AFLP-Analysen. Uwe Sader danke ich für die zuverlässige Erledigung meiner Wünsche an die Werkstatt.

Bei der gesamten Weender Arbeitsgruppe möchte ich mich für das stets gute Arbeitsklima bedanken. Jörg Strobel und Dr. Dirk Gries haben mir die Einarbeitung in die Programmierung der Datalogger sehr erleichtert. Dafür danke ich ihnen. Dr. Heinz Coners danke ich für seine Hilfe bei SoftwareProblemen, Dr. Dietrich Hertel für seine Diskussionsbereitschaft.

Für die Unterstützung der Arbeiten im Gelände danke ich Christoph Fühner, Holger Lieneweg, Ute Luginbühl, Ina Vetter, Dr. Gustav Schulz und Dr. Stephanie Kluth. Sie alle sind bereit gewesen, sich den Witterungsbedingungen auszusetzen, an die eine winterannuelle Art besser angepasst ist als jeder Mensch.

Alexandra Erfmeier danke ich herzlich für die zahlreichen positiven Interaktionen auf den unterschiedlichen raum-zeitlichen Skalenebenen.

Meinen Freundinnen, Freunden, Wohngemeinschaften und Familien danke ich für das angenehme soziale Umfeld, in dem die Arbeit entstanden ist.

Barbara Bauer danke ich herzlich für die Entlastung und Unterstützung in den letzten Tagen der Fertigstellung der Arbeit.

Meinen Eltern Lina und Gustav Schulz danke ich herzlich für ihre generelle Unterstützung, die sich unter anderem darin äußerte, dass sie mir großzügigerweise ihren Campingbus zur Verfügung stellten, ohne den der ,zentrale“ Teil der Arbeit nicht hätte bearbeitet werden können.

Bei meiner Tochter Charlotte bedanke ich mich herzlich dafür, dass ich durch sie immer aufs schönste von den Gedanken an die Arbeit abgelenkt wurde.

Mein ganz besonders herzlicher Dank gilt meiner Frau Stephanie Kluth für Anregungen, Diskussionen und Unterstützung auf allen Skalen- und Metaebenen. 


\section{Lebenslauf}

\section{Persönliche Daten}

Name:

Christian Kluth geb. Schulz

Anschrift:

Arndtstr. 7

37075 Göttingen

$0551 / 380386$

e-mail:ckluth@gwdg.de

Geburtsdatum/-ort: $\quad$ 19.08.1967 in Karlsruhe

Familienstand: $\quad$ verheiratet, 1 Kind (2,5 Jahre)

Staatsangehörigkeit: deutsch

\section{Berufstätigkeit}

Nov. 1998 - Okt. 2001 Wissenschaftlicher Mitarbeiter am Albrecht-von-Haller-Institut für Pflanzenwissenschaften, Abteilung Ökologie, Georg-August-Universität Göttingen, gefördert von der Deutschen Forschungsgemeinschaft (DFG, Br 1698/2)

\section{Promotion}

seit Nov. 1998

„Zentrale und periphere Populationen von Hornungia petraea: Biodiversität und Demographie auf unterschiedlichen raum-zeitlichen Skalenebenen“"

Prüfungsfächer: Botanik, Naturschutz, Agrarökologie

\section{Hochschulbildung}

Diplomarbeit: "Östliche Verbreitungsgrenze von Euphorbia amygdaloides L. und Klimafaktoren in Nordwest-Thüringen“ (Note „Sehr gut")

1992-1997

Georg-August-Universität Göttingen, Hauptstudium Biologie, Schwerpunkte: Botanik, Tropischer und Subtropischer Pflanzenbau, Bodenkunde. Abschluss: Diplom (Note „Sehr gut")

1991-1992

Università degli Studi di Pavia (Italien), Schwerpunkte: Botanik und Angewandte Zoologie (Stipendium der Universität Konstanz)

1989 - $1991 \quad$ Universität Konstanz, Grundstudium Biologie

\section{Zivildienst}

1987-1989

St. Vincentius-Krankenhäuser Karlsruhe

\section{Schulbildung}

$1984-1987$

Bertha-von-Suttner-Schule Ettlingen, Agrarwissenschaftliches Gymnasium, Abschluss: Abitur (Note 2,0)

$1978-1984 \quad$ Realschule Oberreut, Karlsruhe, Abschluss: Mittlere Reife

$1973-1978 \quad$ Grundschule Grünwinkel, Karlsruhe 


\section{Wissenschaftliche Vorträge und Posterpräsentationen}

Sept. 2003

Lieneweg, H., Kluth, C. \& Bruelheide, H.: Which stages in the life cycle of Hornungia petraea are responsible for the species' range limit? - Vortrag, $33^{\text {rd }}$ Annual Conference Ecological Society (GfOE), Halle

Juli 2001

Kluth, C. \& Bruelheide, H.: Are the growing conditions of Hornungia petraea populations more favourable at the species' distribution limit? - Vortrag, $44^{\text {th }}$ IAVS Symposium, Freising-Weihenstephan

Mai 2001

Lieneweg, H., Kluth, C. \& Bruelheide, H.: How does microclimate limit the geographical distribution of Hornungia petraea? - Poster, 14. Arbeitsgruppentreffen "Population Biology of Plants" (GfÖ Gesellschaft für Ökologie), Wien

Mai 2001

Sept. 2000

Kluth, C. \& Bruelheide, H.: Plasticity of ecological traits of central and peripheral populations of Hornungia petraea - Vortrag, 14. Arbeitsgruppentreffen "Population Biology of Plants" (GfÖ Gesellschaft für Ökologie), Wien

Schulz, C. \& Bruelheide, H.: Marginal populations of Hornungia petraea are more viable than central populations - Poster, 30. Jahrestagung der Gesellschaft für Ökologie, Kiel

Mai 2000

Schulz, C. \& Bruelheide, H.: Hornungia petraea populations in Italy and Germany - Poster, 13. Arbeitsgruppentreffen "Population Biology of Plants" (GfÖ - Gesellschaft für Ökologie), Freising

Apr. 2000

Schulz, C. \& Bruelheide, H.: Variation in vegetation of Hornungia petraea populations in Italy and Germany - Vortrag, "Dry grasslands", International Workshop of the European Vegetation Survey, Erice

März 1997

Schulz, C. \& Bruelheide, H.: An experimental study on the impact of winter temperature on the distribution of Euphorbia amygdaloides L. in Central Germany - Vortrag, "Recent shifts in vegetation boundaries of deciduous forests, especially due to global warming", Locarno

Göttingen, 15.03.04 


\section{Publikationen}

Kluth, C. \& Bruelheide, H. (2004) Central and peripheral Hornungia petraea populations: patterns and dynamics. Journal of Ecology, eingereicht.

Kluth, C. \& Bruelheide, H. (2004) Transition rates between life cycle stages in natural populations of the annual plant Hornungia petraea: The combined effect of densitydependence, range position and inter-annual dynamics. Oecologia, eingereicht.

Kluth, C. \& Bruelheide, H. (2004) Using standardised sampling designs from population ecology to assess biodiversity patterns of therophyte vegetation across scales. Journal of Biogeography, 31, 363-377.

Lieneweg, H., Kluth, C. \& Bruelheide, H. (2003) Which stages in the life cycle of Hornungia petraea are responsible for the species' range limit? Biodiversity - from patterns to processes. Verhandlungen der Gesellschaft für Ökologie, Band 33.

Kluth, C. \& Bruelheide, H. (2001) Plasticity of ecological traits of central and peripheral populations of Hornungia petraea. Evolution and Plasticity of Plants - Contributions of the $14^{\text {th }}$ meeting of the Working Group "Population Biology of Plants" (GfÖ - Gesellschaft für Ökologie). Vienna $23^{\text {rd }}-27^{\text {th }}$ May 2001. Institute of Botany, University of Agricultural Sciences Vienna, Austria.

Kluth, C. \& Bruelheide, H. (2001) Are the growing conditions of Hornungia petraeapopulations more favourable at the species' distribution limit. Abstracts - Vegetation and Ecosystem Functions. $44^{\text {th }}$ IAVS Symposium 29 July - 4 August 2001 FreisingWeihenstephan, Germany.

Schulz, C. \& Bruelheide, H. (1999) An experimental study on the impact of winter temperature on the distribution of Euphorbia amygdaloides L. in Central Germany. Recent shifts in vegetation boundaries of deciduous forests, especially due to global warming (eds F. Klötzli \& G. R. Walther), pp. 121-150. Birkhäuser, Basel. 